\title{
Currículo, Educação Popular e Responsabilidade Social na Universidade
}




\section{FICHA TÉCNICA}

\section{Título}

\section{Currículo, Educação Popular e Responsabilidade Social na Universidade}

\section{COLECÇÃo}

Educação, Território e Desenvolvimento Local

\section{COORDENAÇÃo DA COLECÇÃo}

Bravo Nico

\section{ORGANIZADORES}

Bravo Nico e Lurdes Pratas Nico

(C) dos autores (c) desta edição

Universidade Popular Túlio Espanca

da Universidade de Évora (UPTE/UÉ)

UNIVERSIDADE POPULAR TÚLIO ESPANCA

UNIVERSIDADE DE ÉVORA

Apartado 9A, 7002-954

www.utulioespanca.uevora.pt

\section{CAPA E DESIGN}

Carlos Gonçalves

\section{IMPRESSÃO E ACABAMENTO}

Printhaus

\section{DEPÓSITO LEGAL}

$450297 / 18$

\section{IS BN}

978-989-8557-93-3

DATA

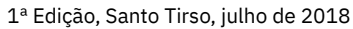

\section{APOIOS}

- Fundação Calouste Gulbenkian

Programa Gulbenkian Qualificação Novas

Gerações

Projetos de Desenvolvimento do Ensino Superior

Projetos Inovadores no Domínio Educativo 2014

- Centro de Investigação em Psicologia e Educação

da Universidade de Évora (CIEP)

Departamento de Pedagogia e Educação/Escola de

Ciências Sociais da Universidade de Évora

Diário do SUL

SUÃO - Associação de Desenvolvimento Comunitá-

rio / Escola Comunitária de São Miguel de Machede

\section{SEJA ORIGINAL! DIGA NÃO À CÓPIA}

\section{EDIÇÃo}

DE FACTO EDITORES

Rua de S. Bento, $93,6 .^{\circ}$ andar, sala 3

4780-546 Santo Tirso - Portugal

geral@defactoeditores.pt

www.defactoeditores.pt

\section{DE FACTO}

\section{EDITORES}

RESERVADOS TODOS OS DIREITOS.

Esta edição não pode ser reproduzida nem transmitida, no todo ou em parte, sem prévia autorização escrita da editora. 


\section{ÍNDICE}

INTRODUÇÃO.

CAPÍTULO 1

A EXTENSÃO E A MISSÃO DA UNIVERSIDADE:

A SINTONIZAÇÃO COM A REALIDADE

CAPÍTULO 2

A UNIVERSIDADE POPULAR TÚLIO ESPANCA/UNIVERSIDADE DE ÉVORA: UM PROJETO EDUCATIVO PARA O ALENTEJO

CAPÍTULO 3

O CASO DE ALANDROAL: ONDE A EXTENSÃO SE CASOU COM A INVESTIGAÇÃO CIENTÍFICA E A FORMAÇÃO

CAPÍTULO 4

O PROJETO «CURRÍCULO, EDUCAÇÃO POPULAR E

RESPONSABILIDADE SOCIAL NA UNIVERSIDADE»

CONCLUSÃO

REFERÊNCIAS BIBLIOGRÁFICAS 
Os textos foram elaborados de acordo com os critérios dos respetivos autores, pelo que coexistem diversas regras ortográficas. 
Publicação apoiada pelo projeto «Currículo, Educação Popular e Responsabilidade Social na Universidade», promovido pela Universidade Popular Túlio Espanca/Universidade de Évora e financiado pela Fundação Calouste Gulbenkian, no âmbito do Programa de Projetos de Desenvolvimento do Ensino Superior - projetos Inovadores no Domínio Educativo 2016. 


\section{Publicações Anteriores}

NICO, Bravo, COSTA, Eduardo \& NICO, Lurdes (Orgs.) (2004). Aprender no Alentejo - I Encontro Regional de Educação. Évora: Departamento de Pedagogia e Educação da Universidade de Évora / ISBN 97298134-4-7/ (http://hdl.handle.net/10174/18776) / (http://dx.doi. org/10.5935/972-98134-4-7.2016B001)

NICO, Bravo, COSTA, Eduardo, MENDES, Paulo \& NICO, Lurdes (Orgs.) (2004). Aprender no Alentejo - II Encontro Regional de Educação. Évora: Departamento de Pedagogia e Educação da Universidade de Évora/ Depósito Legal 220 706/04/ / (http://hdl.handle.net/10174/18779) / (http://dx.doi.org/10.5935/ref.20160004)

NICO, Bravo, COSTA, Eduardo, MENDES, Paulo, NICO, Lurdes \& RODRIGUES, Jorge (Orgs.) (2005). Aprender no Alentejo - III Encontro Regional de Educação. Évora: Departamento de Pedagogia e Educação da Universidade de Évora/ISBN 872-98136-6-3/ (http://hdl.handle.net/10174/18775) / (http://dx.doi.org/10.5935/972-98136-6-3.2016B001)

NICO, Bravo, NICO, Lurdes, DIAS, Catarina, RODRIGUES, Jorge, MAURÍCIO, Patrícia, MENDES, Paulo \& SILVA, Joana (Orgs.) (2008). Aprender no Alentejo - IV Encontro Regional de Educação. Évora: Departamento de Pedagogia e Educação da Universidade de Évora / ISBN 978-989-95802-0-6/ (http://hdl.handle.net/10174/18781) / (http:// dx.doi.org/10.5935/978-989-95802-0-6.2016B001)

NICO, Bravo (Coord.), NICO, Lurdes, FERREIRA, Fátima \& TOBIAS, Antónia (Orgs.) (2011). Escola(s) do Alentejo: um mapa do que se aprende no Sul de Portugal. Mangualde: Edições Pedago/ ISBN 978989-8449-14-6/ (http://hdl.handle.net/10174/2900) / (http://dx.doi. org/10.5935/978-989-8449-14-6.2016B001)

NICO, Bravo (Coord.), NICO, Lurdes, FERREIRA, Fátima \& TOBIAS, Antónia (Orgs.) (2014). Educações no Alentejo. Mangualde: Edições Pedago e Universidade de Évora/ Depósito Legal 375479/14/ (http://hdl.handle. net/10174/8597) / (http://dx.doi.org/10.5935/375479/14.2016B001)

NICO, Bravo \& NICO, Lurdes (Orgs.) (2016). Didáticas do Alentejo. Ramada: Edições Pedago e Universidade de Évora / ISBN 978-989-8655-73-8 / (http://dspace.uevora.pt/rdpc/handle/10174/18918) / (http://dx.doi. org/10.5935/978-989-8655-74-5.2016B001) 


\section{INTRODUÇÃO}

A Educação é um processo social, através do qual ocorre a partilha do conhecimento e se promove o desenvolvimento humano. No ensino superior, este perímetro é, ainda mais, evidente, pela natureza das aprendizagens que, ali, se concretizam e pelo impacto que o resultado das mesmas tem no desenvolvimento, nas oportunidades das pessoas que frequentam as academias e no progresso social e económico dos territórios onde aquelas instituições se localizam. Frequentar e aprender, numa instituição de ensino superior, constitui um elemento valorizador para quem concretiza este segmento do direito à educação. Simultaneamente, as existência e atividade de uma instituição de ensino superior é, nos contextos territoriais em que esta se localiza, um fator crítico de desenvolvimento social e económico.

Neste contexto, em particular no caso de instituições públicas de ensino superior (como é o caso da Universidade de Évora) e em regiões com índices de desenvolvimento humano, social e económico mais frágeis (como é o caso da região Alentejo), às dimensões da investigação científica e da formação graduada e pós-graduada, dever-se-á considerar um forte pilar do serviço à comunidade, na definição conceptual da missão institucional e na concretização operacional da mesma.

O serviço à comunidade deverá materializar-se, através de uma atitude aberta e de diálogo com o território e respetivas dinâmicas humanas, sociais, culturais e económicas e de uma ação empreendedora que mobilize a academia, disponibilizando os seus recursos científicos, humanos, técnicos, tecnológicos, pedagógicos e culturais à comunidade em que se inscreve.

Foi com este entendimento do que é a missão da Universidade de Évora que, em 2009 é fundada a, então denominada, Universidade Sénior Túlio Espanca, entretanto, renomeada, em 2014, Universidade Popular Túlio Espanca/UPTE (art. ${ }^{\circ} 80 .^{\circ}$ dos Estatutos da Universidade de Évora/ 
Despacho Normativo n. ${ }^{\circ} 10 / 2014$, publicado no Diário da República n. ${ }^{\circ}$ 149, Série II de 5 de Agosto de 2014).

A Universidade Popular Túlio Espanca da Universidade de Évora (UPTE/UÉ) é criada, em 2009, como resultado de uma parceria entre a Universidade de Évora e a região Alentejo, aí representada pelas seguintes instituições:

i) a Direção Regional de Educação do Alentejo;

ii) a empresa Delta Cafés;

iii) o grupo de comunicação social Diário do SUL;

iv) a SUÃO-Associação de Desenvolvimento Comunitário.

Desde a sua fundação, a UPTE/UÉ assumiu, como elemento central da sua arquitetura científica e da sua ação, uma relação estreita, ativa e cooperante com a região, na criação e disponibilização de oportunidades de acesso à educação, através de modalidades de aprendizagem de natureza não formal e matriz popular e comunitária. Concorre, para este projeto de educação popular, o universo de recursos da Universidade de Évora, nas suas dimensões científica, tecnológica, cultural e humana. Estão convocados para darem o seu contributo, investigadores, docentes e discentes, no âmbito da respetiva área de investigação, docência e formação.

O modelo de interação com o território e as comunidades locais foi sendo desenhado e concretizado, através do estabelecimento de uma rede de cooperação, assente em parcerias formais com instituições representativas de cada local. Assim foram sendo criados os seguintes polos da UPTE/UÉ:

i) 2009 - Polo de São Miguel de Machede, instalado na Escola Comunitária de São Miguel de Machede e promovido pela SUÃO-Associação de Desenvolvimento Comunitário;

ii) 2010 - Polo de Alandroal, promovido pela Câmara Municipal de Alandroal;

iii) 2010 - Polo de Viana do Alentejo, promovido pela Câmara Municipal de Viana do Alentejo;

iv) 2011 - Polo de Portel, promovido pela Câmara Municipal de Portel e integrando a Universidade Sénior de Portel, que o antecedeu;

v) 2016 - Polo de Canaviais, promovido pela Junta de Freguesia de Canaviais e pela Casa do Povo de Canaviais, onde tem a sua localização;

vi) 2017 - Polo de Barrancos, promovido pela Câmara Municipal de Barrancos;

vii) 2017 - Polo de Reguengos de Monsaraz, promovido pela Câmara Municipal de Reguengos de Monsaraz. 
É nesta dinâmica de serviço à região e respetivas comunidades locais que a UPTE/UÉ promove, em 2014, a sua primeira candidatura ao Programa Gulbenkian Qualificação das Novas Gerações/Projetos de Desenvolvimento do Ensino Superior/Projetos Inovadores no Domínio Educativo, através do projeto «Janelas Curriculares de Educação Popular no Ensino Universitário», no âmbito do qual inicia uma inovadora abordagem, no processo de desenvolvimento curricular em contexto universitário, introduzindo o conceito de Janela Curricular de Educação Popular (Nico \& Nico, 2016a:41), entendido como sendo:

episódios de educação popular de perfil não formal e intergeracional desenhados e concretizados no seio dos planos de estudo curriculares disponibilizados pela Universidade de Évora, no âmbito da sua oferta formativa regular. Estas atividades são previamente negociadas e definidas pelos docentes e discentes, nas unidades curriculares em que as mesmas ocorrem, e oportunamente divukgadas, no âmbito do projeto educativo da Universidade Popular Túlio Espanca, para cada ano letivo.

Em 2016, no âmbito de nova edição do Programa Gulbenkian Qualificação das Novas Gerações, a UPTE/UÉ apresentou uma segunda candidatura, com o projeto «Currículo, Educação Popular e Responsabilidade Social na Universidade». Neste segundo momento, a UPTE/UÉ assume a construção e disponibilização de modalidades de educação não formal como um instrumento enriquecedor da aprendizagem dos estudantes da academia e, também, como uma forma privilegiada de concretização da responsabilidade social da Universidade de Évora, perante a região e as comunidades que a acolhem.

O presente livro mostra, de forma necessariamente abreviada, o pensamento que presidiu à conceção deste último projeto e a respetiva concretização, ao longo dos anos letivos 2016/2017 e 2017/2018. 


\section{CAPÍTULO 1}

\section{A EXTENSÃO E A MISSÃO DA UNIVERSIDADE: A SINTONIZAÇÃO COM A REALIDADE}

\subsection{O DIÁLOGO DAS UNIVERSIDADES COM O TERRITÓRIO E AS COMUNIDADES LOCAIS}

A Universidade concretiza a sua missão, através da promoção da investigação científica e consequente produção do saber, da formação que disponibiliza aos seus estudantes e do serviço à comunidade, que concretiza, através das suas atividades de extensão.

Neste contexto institucional, as instituições universitárias devem materializar as suas atividades de extensão, através da promoção de contextos académicos, nos quais a ciência, a cultura, a tecnologia e a formação graduada e pós-graduada cooperem, se complementem e enriqueçam mutuamente, estando disponíveis, de forma articulada, para as comunidades locais com as quais a universidade interage e perante as quais tem uma responsabilidade institucional e social.

Neste entendimento, as atividades de extensão devem ser assumidas como um pilar estruturante da missão da universidade, em plano de equivalente importância, relativamente aos restantes pilares, na certeza de que, através da sua adequada promoção e concretização, se podem, simultaneamente, promover e enriquecer as atividades de investigação científica e de formação.

Na realidade, através das suas atividades de extensão, as universidades estabelecem um privilegiado contacto com a realidade, em particular com aquela de que fazem parte integrante. Esta interação é uma extraordinária oportunidade de as universidades receberem e acolherem, nas suas políticas de investigação científica e de formação, os contributos das dinâmicas sociais e económicas do contexto territorial em que se encontram. Ao concretizarem um diálogo, aberto e cooperativo, com a sua circunstância territorial e social, as universidades sintonizam-se com a realidade aí existente e podem orientar a sua ação, no sentido de contribuírem, com os seus recursos, para as mais adequadas respostas aos desafios e às necessidades que a realidade, em cada momento, revela. 
Um diálogo, sistemático, aberto e cooperativo, com o território onde se situa e com as comunidades locais aí existentes, deverá ser uma das bases de umas, atentas, inteligentes e úteis, políticas científica e de formação de qualquer instituição de ensino superior. Na realidade, este exercício de interação permite que estas instituições possam identificar os principais desafios sociais, económicos e culturais desses territórios e das suas comunidades, os quais são, frequentemente, excelentes pontos de partida para a definição de políticas de investigação e de formação direcionadas para questões que são sempre, social económica e culturalmente, relevantes e instrumentais. Desta forma, as universidades beneficiam de duas formas:

1. Por um lado, têm a oportunidade de definir linhas de investigação científica, a partir de problemas reais, facto que lhes confere uma relevância social, económica e cultural que, de outra forma, dificilmente assumiriam. Estas fileiras de investigação, suportadas por desafios e necessidades suscitados pela realidade concreta, são, na atualidade, muito valorizadas e objeto de financiamentos prioritários, em todos os quadros de apoio à investigação científica, nomeadamente aqueles para quem são convocados recursos públicos, de âmbito europeu ou nacional;

2. Por outro lado, as linhas de investigação científica, baseadas em desafios da realidade concreta dos territórios e das respetivas comunidades em que as universidades se inserem, são excelentes oportunidades destas diferenciarem o seu perfil científico, uma vez que isso declina a singularidade que sempre se verifica nas dimensões territoriais e comunitárias dos seus contextos singulares. A diferenciação científica decorrente da interação entre as universidades e o território e as comunidades locais é uma vantagem e não uma desvantagem competitiva, pelo que as universidades devem aprofundar este diálogo com os seus contextos específicos, no pressuposto de que, do mesmo, resultará uma coordenada científica mais específica e peculiar, facto que concorre para a diferenciação e reforço do pilar da investigação científica e para o consequente contributo na missão das instituições.

Neste, ampliado e enriquecido, perímetro dos papel e contributo das atividades de extensão para o cumprimento da missão das universidades, em particular no impulso que podem dar para a definição de políticas de investigação científica e de formação diferenciadas, importa encarar a extensão universitária como um importante instrumento de desenvolvimento institucional e não apenas como o, elementar e ornamental, elemento de concretização da responsabilidade social das instituições, numa perspetiva vertical e sobranceira de disponibilização de algo que se possui a alguém que dele necessita. As atividades de extensão devem 
ser encaradas com outra importância estratégica pelas universidades e pelos territórios e comunidades aí existentes, pois do trabalho, aberto e cooperativo, que se pode estabelecer, poderão resultar significativos contributos para o desenvolvimento de ambas as partes desta parceria.

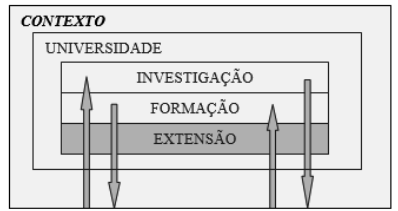

Figura 1 - O diálogo entre a extensão e os restantes pilares da missão da Universidade

As quantidade e qualidade das relações entre as instituições de ensino superior e os respetivos territórios e comunidades depende, naturalmente, das características intrínsecas de ambas as partes. No entanto, o perfil da relação que se estabelece dependerá mais da singularidade da circunstância territorial do que da natureza das instituições de ensino superior, uma vez que estas últimas possuem uma geometria organizacional e funcional muito padronizada, atendendo à sua natureza estrutural e matricial mais institucionalizada e consolidada. O território é, nestas circunstâncias, o elemento diferenciador que pode conferir um perfil distinto à relação que se estabelece com as instituições de ensino superior nele presentes.

Tendo consciência e valorizando esta dimensão diferenciadora que os contextos territoriais e comunitários podem proporcionar às relações que estabelecem com as instituições nele existentes, as universidades devem aproveitar essa riqueza decorrente da singularidade dos seus contextos e transformar essa circunstância numa variável poderosa para a respetiva especialização e diferenciação, ao nível da suas políticas de investigação científica e de formação.

Não se trata de promover um processo de circunscrição ou delimitação, territorial ou local, das atividades científica e formativa, mas, pelo contrário, de uma oportunidade de, a partir do singular, estabelecer uma estratégia de diferenciação, num contexto onde esta é cada vez mais difícil, mas cada vez mais necessária para a afirmação das universidades, num mundo global em que coexistem e competem pela notoriedade e, consequentemente, pela preferência de estudantes, clientes e financiadores.

\subsection{0 diálogo entre a investigação científica, a formação e a extensão, nas universidades}

Como já foi referido, o território é o elemento mais diferenciador na interação que se estabelece entre este e as universidades. Em cada 
território e em cada momento, os desafios societais que se colocam resultam das dinâmicas endógenas e de variáveis muito diferenciadas e específicas de cada contexto, como a geografia, a demografia, o povoamento, a saúde, a educação, a solidariedade social, a economia, a cultura, o ambiente, o património, os recursos naturais, a biodiversidade, entre outras. Este, complexo, ativo e mutável, sistema de variáveis intrínsecas de cada território determina-lhe uma equação singular - na qual o peso e a relevância de cada uma das variáveis é, também, um elemento específico - que comporta as suas necessidades, os seus problemas, o seu potencial e os seus desafios.

Conhecer esta equação territorial e a presença e o peso de cada uma das variáveis referidas é um dos principais exercícios de investigação científica que pode ser assumido pelas universidades e um dos principais contributos que estas podem disponibilizar aos territórios em que se encontram. Na realidade, se considerarmos as múltiplas dimensões que a realidade nos oferece, como objeto de estudo - das dimensões humana e natural, das questões sociais às culturais, da tecnologia ao património, da biodiversidade à literatura, da educação à saúde ou em qualquer outra dimensão que se queira considerar - teremos, à nossa disposição, um conjunto muito amplo de oportunidades de criação e desenvolvimento de fileiras de investigação, nas quais podemos encontrar singularidades que podem assumir-se como excelentes pontos de partida para a produção de saber. Um saber gerado nas dimensões endógenas das circunstâncias de cada instituição, mas de relevância universal, pela especificidade da sua natureza e do respetivo enquadramento no universo do conhecimento.

É através de uma concretização, inteligente e estratégica, das atividades de extensão que será possível identificar e valorizar aquelas variáveis específicas atrás referidas. Interagir com os territórios, neles identificando e caracterizando as suas especificidades, sinalizando as suas necessidades, conhecendo os seus recursos e assumindo os seus desafios é uma tarefa da extensão de qualquer universidade, nomeadamente das que se localizam nas regiões menos desenvolvidas mas, simultaneamente, as mais ricas em necessidades e desafios e as que mais carecem do contributo do conhecimento para estabelecerem estratégias sustentáveis de desenvolvimento.

\subsection{1. $O$ caso da Universidade de Évora}

O caso concreto da Universidade de Évora é um bom exemplo da importância desta interação e das consequências positivas que a mesma pode ter no trabalho científico da academia.

Assumindo o Alentejo, como o seu território de localização e o seu contexto humano e social de acolhimento, a Universidade de Évora tem sido, no passado recente e na atualidade, uma instituição importante 
nos processos de pensamento e de concretização das dinâmicas de desenvolvimento da região. No entanto, esse papel poderá ser potenciado, se as circunstâncias, as necessidades e os desafios do Alentejo forem assumidos pela instituição, como pontos de partida para a definição de algumas das fileiras mais estruturantes das suas políticas científica e de formação.

$\mathrm{Na}$ atualidade, o Alentejo encerra desafios importantes para o seu desenvolvimento e que são, concomitantemente, alguns dos mais estruturantes e complexos desafios com que as sociedades ocidentais estão confrontadas. Deixamos, aqui, sete desafios para o Alentejo e para a Universidade de Évora.

\subsubsection{Os desafios do Alentejo e da Universidade de Évora}

\section{0 desafio demográfico}

A demografia do Alentejo - e de todo o interior de Portugal - é uma, das mais exigentes e complexas, variável da equação do seu desenvolvimento. A baixa natalidade, a alta taxa de envelhecimento e o crescente despovoamento do território configuram, na atualidade, um cenário prospetivo muito preocupante, com consideráveis consequências nas dimensões humana, social, económica.

Nesta questão particular, o Alentejo pode ser considerado um «laboratório vivo", onde estão a ocorrer os fenómenos demográficos que, mais cedo ou mais tarde, atingirão grande parte das regiões equivalentes de muitos outros países e regiões. Esta circunstância específica do Alentejo pode e deve ser encarada como uma oportunidade, pela Universidade de Évora, uma vez que, aqui e nas atuais condições, podem ser estruturadas fileiras de investigação científica em áreas críticas para as sociedades atuais, nomeadamente para aquelas que, com alto grau de probabilidade, irão viver aquilo que o Alentejo vive, no presente.

Conhecer, analisar e compreender as dinâmicas demográficas da região - avaliando o impacto que as mesmas estão a provocar nos sistemas sociais (saúde, educação, proteção social), nos serviços públicos, nos sistemas económicos, culturais, de mobilidade e comunicação, na gestão dos recursos naturais, nas relações entre as pessoas e entre estas e o seu território ou em qualquer outra dimensão que se queira considerar -, produzindo conhecimento científico que suporte novas políticas públicas e novos padrões de atuação, é um exercício científico da maior pertinência e um dos mais importantes serviços públicos que se podem prestar ao país e aos contextos europeu e global a que pertencemos; 


\section{0 desafio energético}

A transição energética é uma inevitabilidade para a humanidade. $\mathrm{O}$ esgotamento das reservas de combustíveis fósseis e as limitações impostas à sua utilização, em consequência das alterações climáticas que provocam e a que estamos a assistir, irão determinar a alteração do paradigma energético, a breve prazo. Esta transição para uma base energética de produção renovável e com menos impactos ambientais e/ou climáticos ocorrerá de forma mais ou menos planeada e com maiores ou menores consequências para o quotidiano das populações, de acordo com a capacidade que cada sociedade tiver para promover, inteligente e estrategicamente, esse processo.

O Alentejo - devido à sua localização geográfica, natureza territorial que apresenta, clima que tem, densidade populacional que o caracteriza, dinâmica económica que revela, infraestruturas que já possui e, principalmente, recursos energéticos de fonte renovável que proporciona - poderá ser um verdadeiro laboratório energético, no qual se poderão concretizar, de forma controlada, programada e segura, as mudanças que promovam esta transição energética necessária e inevitável.

O Alentejo deve estar na vanguarda deste processo de transição energética, a nível nacional e internacional, e a Universidade de Évora deve estar no alicerce científico desta importante e decisiva operação, liderando o processo de desenho e operacionalização deste novo paradigma da energia e tornando-se, dessa forma, uma das referências científicas, nesta área, a nível internacional.

\section{0 desafio agroalimentar}

A fileira agroalimentar, passando pela produção, transformação, comercialização e consumo de alimentos é, na atualidade, uma das dimensões mais críticas para as regiões e os países. Na realidade, a capacidade de os territórios produzirem, de forma sustentável, ambientalmente correta e com a quantidade e qualidade adequadas para a satisfação da procura interna e para a criação e sustentação de uma capacidade exportadora que crie riqueza e mantenha a utilização ativa e inteligente dos recursos naturais, mantendo as pessoas nos territórios, é uma finalidade estratégica de qualquer modelo de desenvolvimento local, regional e nacional.

O Alentejo possui, no presente, um conjunto de infraestruturas de inigualável valor e potencial, das quais se poderão indicar os recursos hídricos hoje disponíveis, a qualidade dos solos, um clima favorável para a atividade agropecuária, um ambiente empresarial em profunda transformação, uma incorporação crescente de tecnologia, a inovação que desponta em muitos setores e uma representação social que voltou 
a valorizar as atividades do setor primário, facto que não é alheio o processo de fixação de um número significativo de jovens qualificados em muitas áreas deste setor de atividade.

Neste contexto atual do setor agroalimentar, a Universidade de Évora assumindo um dos seus setores mais robustos, desde a sua refundação - deverá ter um papel mais presente e ativo, na dimensão científica desta área, assumindo-se como uma das referências mundiais, numa área científica em que o seu território a convoca para a assunção desse estatuto liderante.

\section{0 desafio ambiental}

A dimensão ambiental - muito interrelacionada com as dimensões energética e agroalimentar - é crítica para qualquer território, na assunção de que é indissociável de qualquer modelo de desenvolvimento que assente na sustentabilidade da exploração dos recursos, na compatibilidade entre a qualidade de vida humana e o respeito e valorização da biodiversidade e numa organização social que privilegie um contrato social justo entre as gerações atuais e as gerações futuras, que deverão usufruir dos mesmos recursos que temos à nossa disposição.

Nesta dimensão, o Alentejo é, novamente, um caso muito estimulante para a investigação científica, uma vez que reúne, dentro de si, os desafios referidos anteriormente e as condições para os assumir e resolver, de forma adequada e referencial. O ecossistema e a biodiversidade do montado são, nesta dimensão, o exemplo de um património único e de valor inestimável para a investigação científica e consequente formação daí decorrente. Neste contexto, o papel da pesquisa científica é decisivo para um adequado enquadramento dos desafios ambientais que se colocam às sociedades atuais, a identificação dos principais problemas que eles suscitam e a procura, inteligente e objetiva, das respetivas soluções. A Universidade de Évora pode, uma vez mais, liderar uma fileira de investigação, se conseguir assumir um diálogo estreito e ativo com uma região que lhe oferece uma oportunidade única, pelas características que possui e pelo potencial que representa, nesta área

\section{0 desafio da saúde}

A demografia, a geografia alentejanas são um dos maiores desafios que o Serviço Nacional de Saúde tem, na atualidade. A baixa natalidade, a alta taxa de envelhecimento, um povoamento concentrado, mas com forte isolamento, numa região de baixa densidade, os hábitos de vida, alguns erros no perfil alimentar mais recente e outras variáveis endógenas da região constituem uma, complexa e sistémica, realidade social que é um dos mais exigentes desafios para os sistemas de saúde 
e de proteção social a eles associados. O que se passa no Alentejo, nesta área, antecipa o que se passará noutros contextos geográficos e o conhecimento que se produzir na região alentejana será, certamente, muito útil para os que se seguem.

Nesta área tão crítica para a vida das pessoas e para as dinâmicas sociais e económicas, a Universidade de Évora, pese embora a não existência de uma Escola ou Faculdade de Medicina, possui uma responsabilidade incontornável, não só pelo facto de ter, no seu seio, uma prestigiada Escola Superior de Enfermagem, mas também devido ao facto de muitas das respostas a considerar, para os desafios que se colocam, assentarem numa perspetiva não exclusivamente médica, mas convocarem outras áreas do saber, como a gestão das instituições de saúde, as tecnologias da saúde, os serviços de apoio social, os cuidados domiciliários, a institucionalização de pessoas e todas as dimensões aqui a considerar, a promoção de estilos de vida saudáveis, a literacia em saúde, etc.

\section{0 desafio da inclusão}

As regiões de baixa densidade têm, irreversivelmente, um grande desafio pela frente: como atrair e fixar pessoas. Este desafio é estruturante para o respetivo desenvolvimento e da sua resolução dependerá, inevitavelmente, o seu futuro.

Com a atual estrutura demográfica, o Alentejo, se não conseguir atrair um número significativo de pessoas, será, nas próximas duas a três décadas, um território marcadamente despovoado em muita da sua extensão, com exceção de alguns, poucos, polos urbanos, nos quais se irão concentrar as pessoas, os serviços públicos, as empresas e as dinâmicas sociais e culturais. O cenário prospetivo é, na atualidade, um exercício de baixa probabilidade de erro, bastando, para o efeito, projetar, para o futuro imediato, o que tem acontecido, no passado recente.

Atrair, integrar e fixar pessoas, independentemente da sua origem geográfica, social, cultural e económica é a única alternativa para uma região em, acentuada e dramática, quebra populacional e com um cenário próximo da catástrofe demográfica.

Neste difícil contexto, o contributo da ciência poderá revelar-se estruturante para o desenho de uma estratégia de médio e longo prazo que possa mitigar e inverter as consequências da atual situação. Para a resolução desta difícil equação, são convocadas muitas áreas do saber, entre as quais destacamos: a Demografia, a Sociologia, a Economia, a Educação, a Saúde, a História, as Línguas e Literaturas, o Desenvolvimento ou a Ciência Política. 


\section{0 desafio da educação}

Para lá das questões decorrentes da necessidade de se garantir um sistema de qualificação acessível e com qualidade, para nele se concretizar a educação e formação dos cidadãos e se construir um robusto contributo para o desenvolvimento social e económico da região, a criação de melhores e mais adequados acessos à Educação, para todas as pessoas, independentemente da idade, residência, nível socioeconómico, contexto cultural, estatuto profissional ou nível de escolaridade ou origens geográficas, é um dos maiores desafios que territórios como o Alentejo enfrentam.

As baixas qualificações académicas da população, uma rede escolar ausente de muitos dos contextos territoriais, a inexistência de uma política de educação de adultos permanente e acessível e os reduzidos hábitos de participação em atividades de educação ao longo da vida caracterizam o Alentejo. É neste contexto que a Universidade de Évora tem disponível para, na e com a região, assumir um dos seus mais audaciosos desafios: desenhar e concretizar um amplo projeto educativo que congregue as três dimensões da sua missão: a investigação científica, a formação e a extensão. Esse projeto chama-se Universidade Popular Túlio Espanca/Universidade de Évora e foi fundado no ano 1999. 


\section{CAPÍTULO 2}

\section{A UNIVERSIDADE POPULAR TÚLIO ESPANCA/ UNIVERSIDADE DE ÉVORA: UM PROJETO EDUCATIVO PARA O ALENTEJO}

A Universidade Popular Túlio Espanca/Universidade de Évora (UPTE/ UÉ) foi fundada no ano 2009 e, desde o seu início, foi assumida, estatutariamente, pela academia eborense, como uma unidade científico-pedagógica. O enquadramento institucional deste projeto de extensão universitária determinou-lhe, desde o primeiro momento, um claro desafio: promover o diálogo, ativo e cooperativo, entre os três pilares da missão da Universidade de Évora: a investigação científica, a formação e a extensão, assumindo esta última como o foco da sua ação.

Na criação da UPTE/UÉ, como já foi referido anteriormente, estiveram envolvidos atores regionais e locais:

- a Direção Regional de Educação do Alentejo;

- a Delta-Cafés;

- o grupo de comunicação social «Diário do SUL»;

- A SUÃO-Associação de Desenvolvimento Comunitário.

Desde a sua criação, a UPTE/UÉ estabeleceu o objetivo estratégico de desenvolver a sua atividade, em estreita parceria com o território da região alentejana, através de alguns dos seus atores mais representativos: as autarquias locais e as instituições da sociedade civil. Por outro lado, assumiu uma orientação clara, no sentido de articular, de forma cooperada e inteligente, as dimensões da investigação científica e da formação graduada e pós-graduada, para que a sua interação com o território e comunidades locais pudesse alimentar e/ou suscitar fileiras de investigação científica e de formação, na área das ciências da educação, na Universidade de Évora.

A rede de educação popular já construída pela UPTE/UÉ - atualmente constituída pelos Polos de Alandroal, Barrancos, Canaviais/Évora, Portel, Reguengos de Monsaraz, São Miguel de Machede/Évora e Viana do Alentejo e assumida como um projeto de educação não formal de perfil preferencialmente intergeracional e promotor do diálogo entre os saberes 
académicos e experienciais - , foi desenhada de forma a considerar dez princípios básicos.

\subsection{Os princípios básicos do modelo educativo da UPTE/UÉ \\ 1. Valorizar e integrar as dinâmicas educativas existentes em cada território}

Em qualquer território, existe uma determinada rede de educação, em contextos formal e não formal, disponibilizada pelo universo de instituições que aí desenvolve a sua atividade e que, nesse contexto, organiza e concretiza oportunidades de aprendizagem, nas quais as pessoas participam, em função das suas necessidades, dos seus interesses e das suas disponibilidades.

O Alentejo é um território que exibe uma grande dinâmica social e institucional, aí se encontrando diversos atores que desenvolvem a sua ação em áreas tão diversas como a cultura, o recreio, o desporto, a saúde, o lazer, a educação popular e comunitária, o associativismo juvenil, as universidades seniores, as associações de idosos, os grupos informais, entre muitos outros exemplos. Em muitos dos concelhos alentejanos, o número destas instituições é muito significativo e a dinâmica que as mesmas desenvolvem é muito intensa, facto que proporciona, às suas populações, um significativo número de oportunidades de participação em atividades com dimensão educativa. A título de exemplo, refere-se o caso de Alandroal, que, em estudo realizado, nos anos 2008-2011, pelo Centro de Investigação em Educação e Psicologia da Universidade de Évora, apresentava 327 instituições ativas, as quais haviam proporcionando, no período de uma década (1997-2007), 734 aprendizagens com algum grau de estruturação (Nico, 2011).

Nestes contextos e com esta riqueza de atividade educativa, era fundamental que a parceria que se viesse a estabelecer entre a Universidade de Évora e o território, através das suas instituições mais representativas (autarquias locais), pudesse considerar, valorizar e promover as dinâmicas educativas já existentes, integrando-as numa nova rede de educação, dando-lhes, dessa forma, mais possibilidades de desenvolvimento.

Foi assim que se passou em quase todos os casos de criação de polos da UPTE/UÉ, de que se apresentam alguns exemplos, pela ordem de criação dos mesmos:

a) No Polo de São Miguel de Machede (2009), integrou-se a Escola Comunitária de São Miguel de Machede;

b) No Polo de Alandroal (2010), integraram-se as atividades educativas já desenvolvidas pela Câmara Municipal e a Escola de Instrumentos Tradicionais de Hortinhas; 
c) No Polo de Viana do Alentejo (2010), integraram-se o Clube de Saúde Sénior e algumas atividades de educação em competências básicas já existentes;

d) No Polo de Portel (2011), integraram-se a Universidade Sénior do Município, bem como algumas atividades culturais já existentes;

e) No Polo de Canaviais/Évora (2016), integrou-se a dinâmica educativa da Casa do Povo de Canaviais;

f) No Polo de Reguengos de Monsaraz (2017), integraram-se algumas atividades desenvolvidas por grupos de jovens e de idosos;

g) No Polo de Barrancos (2018), integraram-se as atividades de natureza cultural já existentes no município.

A cartografia das instituições existentes no território, sinalizando e caracterizando as que exibem práticas com maior potencial educativo, permite um melhor conhecimento da realidade educativa, a sua, mais adequada e complementar, organização, em redes locais e poderá ser um ponto de partida extremamente interessante para a atividade de investigação científica, numa perspetiva de, com o conhecimento produzido, nela se poder intervir. Foi o que aconteceu em Alandroal, caso em que a extensão se aliou à pesquisa científica e à formação graduada e pós-graduada e que será descrito no capítulo seguinte.

\section{Respeitar a autonomia de cada projeto territorial}

O desenvolvimento da rede de educação popular da UPTE/UÉ, para lá de tentar conhecer, valorizar e integrar a realidade educativa de cada contexto territorial, teve, também, a preocupação de respeitar a autonomia de cada experiência concreta, estimulando sempre a capacidade de cada rede local pensar, desenhar, concretizar e avaliar a respetiva atividade. Esta dimensão determinou que cada polo tivesse desenvolvido o seu projeto, de forma singular, convocando os parceiros que entendeu, alocando os recursos que considerou necessários e/ou possíveis, definindo os seus projetos e atividades, de acordo com os seus próprios critérios. Naturalmente que existem algumas características transversais que unem todos os polos da rede (educação popular, de perfil intergeracional, recorrendo e valorizando os recursos endógenos). No entanto, a partir dessa base comum, cada experiência traçou o seu caminho e tem vindo a concretizá-lo, de forma autónoma, numa rede que coopera, mas que não impõe um modelo padronizado de atividades.

Esta autonomia permite a promoção da diversidade de soluções, quase sempre adaptadas às circunstâncias geográficas, demográficas, sociais, económicas e culturais de cada território específico. Por outro lado, favorece, também, a inovação, através da emergência de práticas educativas distintas e da conceção e concretização de projetos originais, os quais se constituem como objetos de estudo muito interessantes para 
algumas das linhas de trabalho científico existentes na Universidade de Évora, nesta área concreta das Ciências da Educação, e uma excelente oportunidade de contacto com a realidade, por parte dos estudantes da Universidade de Évora, nomeadamente dos cursos de licenciatura, mestrado e doutoramento de Ciências da Educação.

Por último, o exercício da autonomia, no desenvolvimento da rede de educação popular da UPTE/UÉ, é um fator de união da mesma, uma vez que o espaço de liberdade e a manifestação de confiança que oferece, a cada polo, é utilizado como elemento de reforço da responsabilidade local e do impulso de iniciativa, fatores que concorrem para a vitalidade de cada uma das experiências.

\section{Promover o trabalho cooperativo}

A par do respeito e da promoção da autonomia de cada polo, na rede de educação popular da UPTE/UÉ, promove-se, de forma sistemática, o trabalho cooperativo, através do qual, os diferentes polos participam nos processos de desenvolvimento da rede e da sua contínua inovação.

Através da cooperação, estabeleceram-se rotinas de trabalho colaborativo, construíram-se projetos comuns, partilharam-se experiências, esclareceram-se dúvidas e, variável muito importante para este projeto educativo, estabeleceram-se laços pessoais entre as pessoas: entre as que coordenam os polos da rede e entre as que participam nas atividades. Na realidade, na atualidade, a UPTE/UÉ é uma, alargada, família, no seio da qual há membros de todas as idades e origens geográficas, sociais económicas e culturais e de todos os saberes. A unir estas pessoas, um elemento comum: o prazer de aprender e de conviver.

A cooperação numa rede de educação popular permite, ainda, ultrapassar as limitações de cada um dos polos. Ao estabelecerem-se estratégias cooperativas, os recursos disponíveis (ideias, pessoas, materiais, financiamentos ou outros) aumentam, uma vez que cada polo poderá recorrer à solidariedade dos outros polos, o que permite aumentar a sua capacidade endógena. Frequentemente, sem envolver recursos financeiros, o trabalho cooperativo é uma adequada forma de se fazer mais com os mesmos recursos ou, em algumas situações, fazer-se mais, com menos recursos, uma vez que poderão ocorrer as denominadas economias de escala.

Não pode ser ignorado o papel da cooperação na dinamização da partilha dos saberes científicos (mais da responsabilidade da academia) e dos saberes experienciais (mais decorrentes dos contributos de cada território). A existência de canais de trabalho colaborativo permite a troca destes saberes, disponibilizando-os a todos os elementos da rede, facto que é um aspeto de grande importância, uma vez que multiplica as oportunidades de aprendizagem de cada elemento integrante da rede. 
Neste aspeto tão relevante da dinâmica educativa da rede, os recursos tecnológicos poderão vir a desempenhar um papel de grande importância, pela capacidade que podem trazer de difusão destes conhecimentos, através das plataformas digitais.

\section{Valorizar os conhecimentos científico e experiencial}

Como já foi referido, uma das linhas transversais do trabalho em desenvolvimento na rede de educação popular da UPTE/UÉ consiste na promoção de um diálogo, mutuamente enriquecedor de todos os saberes presentes nesse contexto: os saberes de perfil científico, resultantes do contributo da Universidade de Évora, e os saberes mais experienciais, resultantes do contributo do território alentejano, nos «sotaques» característicos de cada um dos diferentes contextos de cada polo.

De acordo com este princípio, têm vindo a promover-se projetos que procuram convocar, em simultâneo, as duas categorias de conhecimentos, no sentido de, no desenvolvimento dos mesmos, ser possível, a cada participante, enriquecer o conhecimento que já possui, com o conhecimento a que ainda não acedeu. Isto significa que, para o desenho e concretização destes projetos, são envolvidos docentes e discentes da Universidade de Évora e pessoas de cada um dos contextos, tentando-se avaliar a melhor forma de se construir um contexto de aprendizagem em que ambas as categorias de saberes se encontrem num plano equivalente e disponíveis para todos. Na segunda parte deste livro, serão apresentados alguns exemplos destes projetos.

Este diálogo entre saberes de diferentes origens e legitimidades tem um duplo efeito que é importante referir:

a) por um lado, permite que as pessoas, cujo conhecimento tem uma base mais empírica, tenham acesso ao conhecimento de perfil mais científico, o que lhes permite aceder a outras leituras e interpretações da realidade, valorizando, dessa forma, o conhecimento dos mais jovens, normalmente mais qualificados academicamente;

b) por outro lado, permite que os docentes e, principalmente, os estudantes da universidade tenham acesso aos saberes de perfil mais experiencial e empírico, representativos de uma cultura local extremamente rica, mas muitas vezes desconhecida, desvalorizada e inacessível aos que possuem um conhecimento mais académico. Esta oportunidade de contacto com o património cultural do território enriquece as formações académicas dos estudantes, uma vez que estes poderão valorizar esses saberes, respeitando as pessoas que o detêm. Desta forma, poderão, ainda, desenvolver uma maior sensibilidade social e demonstrar maior respeito e valorização das culturas locais. É, pois, uma oportunidade única de enriquecimento cultural que os estudantes da Universidade 
de Évora têm à sua disposição, que muito contribuirá para a sua formação académica e pessoal e que muito poderá concorrer para uma postura de cidadania mais adequada e sensível para com os seus territórios e comunidades de origem.

\section{Promover a intergeracionalidade}

O modelo educativo da rede de educação popular da UPTE/UÉ assume a intergeracionalidade como um dos seus princípios básicos.

Embora a dimensão demográfica, as exigências profissionais ou o perfil social das comunidades remetam a participação, em atividades educativas desta natureza, para as pessoas mais velhas, nos projetos de educação popular concretizados pela UPTE/UÉ, existe a, permanente e transversal, finalidade de juntar pessoas de todas as idades, em torno de atividades de aprendizagens, nas quais possam interagir.

É através de aprendizagens de perfil intergeracional que, nas comunidades locais, sempre se concretizou a transmissão do legado cultural das gerações mais velhas para as gerações mais jovens. Esta foi sempre uma dimensão estruturante dos contextos locais e comunitários de aprendizagem e uma das garantias de que a herança cultural não ficaria interrompida em qualquer das gerações.

$\mathrm{Na}$ atualidade, à fileira educativa de transmissão do legado dos mais velhos para os mais novos, dever-se-á adicionar a fileira da criação das oportunidades de contacto com os saberes mais contemporâneos e tecnológicos mais próximos dos mais jovens que os poderão disponibilizar aos mais velhos. A dimensão intergeracional dos contextos de aprendizagem promove, pois, o encontro de todas as pessoas e, com isso, o encontro de todos os saberes e de todas as experiências.

Uma outra dimensão da intergeracionalidade decorre da concretização de contextos educativos estruturados em torno de objetos de aprendizagem face aos quais, todos os intervenientes se encontram em plano de igualdade, independentemente das suas idades e experiências vitais. Tal acontece, com uma adequada preparação dos contextos educativos e da criteriosa seleção de objetos de aprendizagem. Quando estes contextos educativos se geram, torna-se possível a existência de processos estruturados de aprendizagem nos quais podem se podem envolver e cooperar pessoas de idades diferentes, variável que, aí, não é relevante.

Por último, a promoção da intergeracionalidade em contextos educativos de educação popular permite, ainda, o estabelecimento de laços pessoais de cooperação e de amizade entre pessoas de distintas idades, fator que fortalece os laços sociais nas comunidades e aumenta a coesão social. 


\section{Promover a participação ativa dos estudantes}

A participação ativa de estudantes em atividades de educação popular da UPTE/UÉ tem sido um dos eixos estruturantes deste projeto educativo, desde o seu início.

A participação discente tem vindo a ser implementada, através de diversas estratégias: a participação livre, o recurso a bolsas institucionais de voluntariado ou através da modalidade mais estruturante de participação da UPTE/UÉ: o projeto Janelas Curriculares de Educação Popular (Nico \& Nico, 2016a). Neste projeto, os estudantes que se disponibilizem para participarem em atividades da UPTE/UÉ, serão convidados a integrarem-se nas dinâmicas educativas dos seus polos e, quando tal for possível e conveniente, a articularem essa sua participação com os seus docentes e envolvendo as suas aprendizagens, no plano curricular do plano de estudos do respetivo curso. Desta forma, a participação discente poderá enquadrar-se no âmbito das unidades curriculares frequentadas, nas quais podem substituir um segmento de aprendizagem ou a produção de elementos de avaliação pela respetiva participação em projetos de educação popular, nos quais demonstrem e apliquem, em contextos reais, os seus conhecimentos e competências académicas.

A fileira de formação graduada e pós-graduada em Ciências da Educação tem sido aquela em que este projeto tem revelado maior potencial e na qual se têm vindo a concretizar algumas das mais interessantes janelas curriculares de educação popular. Deverá referir-se que, na criação dos polos da UPTE/UÉ de Alandroal, Portel, Viana do Alentejo e Barrancos, estiveram, diretamente envolvidos estudantes dos cursos de licenciatura, mestrado e doutoramento em Ciências da Educação da Universidade de Évora. Em alguns destes casos, estudantes residentes nas comunidades em que se criaram os respetivos polos, facto que muito concorreu para demonstrar o papel essencial da extensão nos processos de formação e de investigação científica e vice-versa.

\section{Considerar a realidade na investigação científica}

Como já foi anteriormente referido, uma das finalidades do projeto da UPTE/UÉ consiste em promover um contacto, próximo e frequente, com os diversos contextos educativos da região Alentejo, em particular aqueles que se enquadram no âmbito da educação popular e com quem a Universidade de Évora tem vindo a estabelecer parcerias formais.

Esta proximidade da academia com a realidade educativa do território onde se encontra implantada tem permitido que as fileiras de investigação científica - nomeadamente a linha de trabalho Educação, Território e Instituições, do Centro de Investigação em Educação e Psicologia e a própria UPTE/UÉ, enquanto unidade científico-pedagógica da Universidade de Évora - tenham tido a oportunidade de interagir 
com dinâmicas educativas reais em contexto real e, consequentemente, recebido informação relevante acerca das mesmas. Este manancial informativo e experiencial tem sido determinante para a estruturação de parte do trabalho científico na fileira referida e de o conhecimento gerado pelo mesmo ter vindo a ser transferido para os territórios de origem. As Cartas Educativas dos concelhos de Alandroal e de Portel são dois exemplos destes processos que cruzaram as atividades de extensão e de investigação científica.

Por outro lado, para lá da importante dimensão instrumental e social do conhecimento produzido, a consideração da realidade dos territórios, no desenho e concretização do trabalho científico, permite, ainda, o desenvolvimento de pesquisa em torno de objetos diferenciados. Este facto potencia a especialização inteligente da Universidade de Évora, na área da Educação Popular de perfil intergeracional, o que é complementado pela existência da Universidade Popular Túlio Espanca/Universidade de Évora, uma realidade única no contexto académico em Portugal.

\section{Privilegiar a investigação científica na intervenção na realidade}

Como foi referido, no ponto anterior, a relação entre a investigação científica e os contextos territoriais e comunitários tem vindo a ser privilegiada, no modelo de organização e funcionamento da UPTE/ UÉ. Este facto tem permitido uma intervenção com perfil científico na realidade educativa dos territórios. Como, também, já foi referido, a produção das novas Cartas Educativas de Alandroal e de Portel são dois exemplos evidentes da concretização deste princípio.

A concretização deste princípio permite, também, a transferência e consequente aplicação, real e instrumental, do conhecimento científico, aspeto atualmente muito valorizado nos sistemas de investigação e desenvolvimento de qualquer país.

As proximidade e interação entre os pilares da extensão e da investigação científica, para lá de robustecer a concretização da missão da universidade, permite, ainda, a existência de autênticos laboratórios em contexto real, nos quais se podem testar modelos teóricos e avaliar dos seus resultados ou, em sentido inverso, promover a emergência de racionalidades novas e singulares, a partir da observação e interpretação da própria realidade.

\section{Promover a presença da realidade na formação graduada e pós-graduada}

Em todos os polos da UPTE/UÉ, ocorre a intervenção de estudantes da Universidade de Évora, nomeadamente, como já foi referido, os que frequentam a fileira de formação das Ciências da Educação. Este facto permite que, nos planos de formação destes estudantes, estejam disponíveis dois corredores complementares de aprendizagem: 
a) o corredor curricular formal, normal e decorrente da concretização dos planos de estudo e da frequência das diferentes unidades curriculares;

b) o corredor não formal da educação popular, resultante das oportunidades de participação que os estudantes têm à sua disposição e nas quais podem aplicar os conhecimentos académicos, testando-os, validando-os e enriquecendo-os com os conhecimentos experienciais do território e com os laços sociais que estabelecem com as pessoas com quem contactam.

A presença, simultânea destes dois corredores é um fator distintivo da formação graduada e pós-graduada da Universidade de Évora, na área das Ciências da Educação e um dos aspetos que tem sido valorizado, em procedimentos de avaliação externa destas formações.

\section{Estar presente nas redes de comunicação}

A divulgação da atividade da UPTE/UÉ tem sido uma preocupação, desde o início do projeto. Esta finalidade decorre do facto de o grupo de comunicação social «Diário do SUL» ser uma das instituições fundadoras e de, desde o primeiro momento, ter assumido uma dimensão educadora, na parceria que estabeleceu, com a Universidade de Évora, no âmbito da UPTE/UÉ.

A participação deste grupo de comunicação social, através dos seus órgãos de comunicação (jornal, rádio e TV na internet) possibilita, por outro lado, o estabelecimento de uma nova rede de educação popular, através do recurso a essas plataformas, que cobrem a totalidade do território alentejano.

O projeto «Aula Telefonia» nasceu desta parceria e tem vindo a ser desenvolvido, através da produção e realização de programas radiofónicos (com declinação em reportagens jornalísticas e programas televisivos). Neste projeto concreto, são selecionados temas de relevância regional, que são abordados, alternadamente, na dimensão do saber científico ou na dimensão do conhecimento experiencial. Em 2018, realizaram-se as primeiras "Aulas Telefonias», dedicadas aos seguintes temas: As Vacinas (saber Científico); a Arte Chocalheira (conhecimento experiencial); os Sismos (saber científico). Estão em preparação, no momento em se escrevem estas palavras, as «Aulas Telefonias» dedicadas às Alterações Climáticas (saber científico) e ao Barranquenho (conhecimento popular).

Em preparação, está o recurso às plataformas digitais da Universidade de Évora e às redes sociais, para, através destas, se promoverem outras modalidades de aprendizagem e novas oportunidades de promover o encontro de mais pessoas da rede, em torno de situações de aprendizagem. 
Como se pode depreender da apresentação, descrição e exemplificação dos princípios anteriores, a UPTE/UÉ é, na atualidade, uma década após a sua fundação, um exemplo de como, na Universidade de Évora e na área das Ciências da Educação, se concretizou o cruzamento entre as atividades de investigação científica, de formação e de extensão, a partir destas últimas.

Em todo este caminho já percorrido, para lá dos parceiros locais, com os quais a Universidade de Évora estabeleceu parcerias ativas, foi determinante, entre 2014 e 2018, o apoio da Fundação Calouste Gulbenkian, através do seu Programa Gulbenkian Qualificação das Novas Gerações/ Projetos de Desenvolvimento do Ensino Superior/Projetos Inovadores no Domínio Educativo. Através desta parceria, foi possível desenvolver os projetos «Janelas Curriculares de Educação Popular no Ensino Universitário» (2014-2016) e «Currículo, Educação Popular e Responsabilidade Social na Universidade» (2016-2018), no âmbito dos quais se promoveu, de forma mais ampla e decisiva, a participação dos estudantes em projetos da UPTE/UÉ. 


\section{CAPÍTULO 3}

\section{O CASO DE ALANDROAL: ONDE A EXTENSÃO SE CASOU COM A INVESTIGAÇÃO CIENTÍFICA E A FORMAÇÃO}

Apresenta-se, neste capítulo, o trabalho realizado no concelho de Alandroal, como um caso em que se concretizaram os princípios enunciados na presente obra e pelo exemplo que constitui de um adequado casamento entre os três pilares da missão da Universidade de Évora: a investigação científica, a formação e a extensão.

\subsection{0 início da parceria entre a academia e o território}

Em 2002, foi celebrado o primeiro protocolo de cooperação institucional entre a Universidade de Évora e o município de Alandroal, no quadro da concretização de um projeto de investigação científica conducente à elaboração de uma tese de doutoramento, por parte de José Luís Lagoa D’Orey, estudante da Universidade de Évora (D’Orey, 2009).

Durante um período de quatro anos, foi desenvolvido um estudo que produziu conhecimento sobre o universo institucional do território daquele município, particularmente no que se referiu às instituições (e espaços naturais) que pudessem ser consideradas como recursos curriculares para a abordagem curricular e didática das ciências da natureza no terceiro ciclo do ensino básico.

Na sequência desse trabalho e atendendo ao manancial de informação produzido pela investigação realizada, foi desenhado um projeto de investigação de grande amplitude que tinha, como finalidade, realizar a cartografia educacional completa do território, nele identificando e caraterizando todas as instituições ativas no período 1997-2007 e, nesse universo, identificando as que possuíam potencial educativo. Em simultâneo, seria realizada a cartografia das aprendizagens realizadas pela população adulta, no mesmo período. A este projeto de pesquisa foi dado o nome de "Arqueologia das Aprendizagens no concelho de Alandroal», tendo o mesmo sido candidatado, através do Centro de Investigação em Educação e Psicologia da Universidade de Évora, a financiamento da 
Fundação para a Ciência e Tecnologia, no âmbito do Programa de Apoio a Projetos de Investigação em todas as áreas científicas, no ano de 2006. $O$ projeto veio a ser avaliado positivamente e a ser financiado pela FCT, através da atribuição de um valor de aproximadamente sessenta e nove mil euros, tendo-lhe sido atribuída a referência PTDC/CED/81388/2006.

\subsection{A intervenção da investigação científica}

Durante quatro anos (2008 a 2011), o projeto foi concretizado no terreno. Transcreve-se, nas páginas seguintes, algum do conteúdo do Relatório Final, entretanto produzido e entregue à FCT (Nico, 2012), o qual descreve o que foi realizado, no âmbito daquele projeto, e algumas das relações que se foram estabelecendo entre a investigação científica que era concretizada, a formação pós-graduada e a extensão universitária:

A primeira tarefa a concretizar consistiu na criação, no concelho de Alandroal, de uma base local, que permitisse a instalação e o trabalho da equipa de investigação do projecto. Tal objectivo foi concretizado, no momento inicial do projecto, aquando da realização da Sessão de Apresentação do projecto à população do Alandroal, no dia 16 de Fevereiro de 2008

Na realidade, desde esse momento, o Fórum Cultural Transfronteiriço do Alandroal acolheu, num dos seus espaços, o denominado "Gabinete Local do Projecto Arqueologia das Aprendizagens do Alandroal”, que se veio a assumir como uma importante base de trabalho e que, no momento em que se apresenta 0 presente Relatório, é um espaço físico e humano de trabalho científico em Alandroal que tem a sua permanência assegurada, através de novo Protocolo entre a Câmara Municipal de Alandroal e a Universidade de Évora. Em simultâneo, na sequência de contactos prévios com as seis Juntas de Freguesia do concelho, com as quais a Universidade de Évora celebrou Protocolos de Cooperação, foi possivel dispor de espaços de trabalho em todas as autarquias, realidade que muito contribuiu para a execução do trabalho de campo, nos três anos que se seguiram. No âmbito do Protocolo de Cooperação celebrado entre a Universidade de Évora e a Câmara Municipal de Alandroal, esta última instituição disponibilizou, desde o momento inicial e em dedicação exclusiva, uma técnica superior para dar o apoio necessário à concretização da investigação. Posteriormente, esta colaboração seria reforçada com a afectação de outra técnica superior e de um técnico estagiário, que se mantiveram, até ao final, na equipa local de trabalho.

De referir que estes três colaboradores da Câmara Municipal de Alandroal, entretanto, tornaram-se estudantes da Universidade de Évora, em consequência das respectivas candidaturas aos Cursos de Mestrado em Ciências da Educação/ Especialização em Educação Comunitária (dois casos) e de Licenciatura em Ciências da Educação (um caso). As Juntas de Freguesia, quando tal se revelou necessário, disponibilizaram, também, os seus funcionários para a concretização, no seu território, das actividades de pesquisa. No âmbito da parceria estabelecida 
aquando do processo de candidatura, a Direcção Regional de Educação do Alentejo disponibilizou, pontualmente, o trabalho de uma das suas técnicas superiores, a Delegação Regional do Alentejo do Instituto do Emprego e Formação Profissional (IEFP) disponibilizou informação importante e a SUÃO-Associação para o Desenvolvimento Comunitário contribuiu com o trabalho periódico de três técnicas qualificadas, nos momentos de trabalho de campo. No âmbito dos recursos humanos, é de referir, ainda, o contributo de estudantes do Curso de Licenciatura em Ciências da Educação da Universidade de Évora (em regime de voluntariado, aquando das respectivas pausas escolares) $e$ de jovens estudantes residentes nas freguesias do concelho de Alandroal (durante as férias escolares e no âmbito de projectos de Ocupação de Tempos Livres, promovidos pelas autarquias e apoiados pela Direcção Regional do Alentejo do Instituto Português da Juventude). Nos periodos de recolha de informação, junto das instituições e das pessoas do concelho de Alandroal, o transporte dos elementos da equipa de investigação foi disponibilizado, em muitas situações, pela Câmara Municipal de Alandroal e pela SUÃO-Associação de Desenvolvimento Comunitário. A alimentação, nestes periodos, foi assegurada pela autarquia alandroalense, através do seu refeitório municipal. Numa outra importante dimensão - a informação existente acerca da realidade demográfica, social e educacional do concelho de Alandroal -, foi importante o contributo dado pelos serviços das autarquias locais, da Direcção Regional de Educação do Alentejo, da Delegação Regional do Alentejo do Instituto do Emprego e Formação Profissional e do Governo Civil do Distrito de Évora. Também importante foi o contributo do grupo de comunicação social Diário do SUL, através do qual, foi possível divulgar à população do Alentejo, com regularidade, informação relativa ao projecto de investigação. Na Universidade de Évora, entretanto, a equipa de investigação usufruiu de adequadas condições de trabalho, por parte do Centro de Investigação em Educação e Psicologia e do Departamento de Pedagogia e Educação, este último, através da cedência de um gabinete, no qual foi instalado o centro nevrálgico e operacional de todo o projecto. Durante a concretização do projecto de investigação, foram contratadas duas Bolseiras de Investigação Científica.

A concretização metodológica da investigação (estruturada inicialmente em sede da candidatura à Fundação para a Ciência e a Tecnologia) seguiu uma trajectória técnica e cronológica em que a geografia foi uma variável significativa. $\mathrm{Na}$ realidade, desde o momento inicial, que a investigação havia assumido a necessidade de se definir uma sequência que assumisse a freguesia de Juromenha (Nossa Senhora do Loreto), como o território de teste para todos os passos, instrumentos e técnicas a utilizar. Esta decisão decorreu do facto de esta freguesia ser a de menor dimensão demográfica, nos planos institucional e individual (apenas 12 instituições e 145 pessoas recenseadas pela equipa de investigação). Esta pequena dimensão permitiu a testagem de todas as opções anteriormente indicadas e o respectivo ajuste, em função das indicações recolhidas. 
No decurso da concretização do projecto de investigação, foram sendo promovidas oportunidades de realização de trabalho científico, através da oferta de bolsas de investigação científica, através das quais, dois jovens investigadores tiveram oportunidade de iniciar os respectivos percursos profissionais.

o trabalho académico (projectos de pós-doutoramento, teses de doutoramento e de dissertações de mestrado) foi também uma das principais apostas estratégicas do projecto, no sentido de a pesquisa poder detalhar, de forma mais pormenorizada, aspectos mais particulares da realidade ou, em alguns casos, explorar áreas de potencial investigação ou acção para o futuro. Nestas circunstâncias, foram desenvolvidos os seguintes trabalhos académicos:

\section{Projectos de Pós-Doutoramento}

a) Márcia Alvarenga - Professora da Faculdade de Formação de Professores da Universidade do Estado do Rio de Janeiro e esteve na Universidade de Évora, no âmbito do projecto, tendo em vista participar nas suas actividades e conhecer a realidade educativa de Portugal, em geral e do Alentejo, em particular.

\section{Teses de Doutoramento:}

a) José Luís d'Orey - Frequentou o Curso de Doutoramento em Ciências da Educação na Universidade de Évora. Na sua tese (já concluída e defendida, em provas públicas onde obteve a classificação máxima), demonstrou o contributo que o meio local (Alandroal) pode proporcionar para uma abordagem curricular promotora de literacia científica, no âmbito das Ciências da Natureza do $3^{\circ}$ Ciclo do Ensino Básico promotora de literacia científica, no âmbito das Ciências da Natureza do $3^{\circ}$ Ciclo do Ensino Básico;

b) Luisa Carvalho - Frequentou o Curso de Doutoramento em Ciências da Educação na Universidade de Évora. Na sua tese (já concluída e defendida, em provas públicas onde obteve a classificação máxima), conheceu e caracterizou os estilos comunitários de aprendizagens em indivíduos analfabetos residentes em seis localidades do concelho de Alandroal, com elevadas taxas de analfabetismo: Ferreira de Capelins, Hortinhas, Juromenha, Mina do Bugalho, Montejuntos e Terena;

c) Antónia Vieira Tobias -É bolseira de investigação científica no presente projecto e frequenta o Curso de Doutoramento em Ciências da Educação. Na sua tese (em curso), estuda a dimensão educativa das instituições da sociedade civil localizadas no território do Alandroal, no período 1997-2007, e pretende identificar quais os ambientes de aprendizagem, em contexto institucional, que mais concorreram para a qualificação da população;

\section{Dissertações de Mestrado}

a) Sílvia Rocha-É natural de Alandroal e frequentou o curso de Mestrado em Educação Especial. Na sua dissertação (já concluída e que será defendida, publicamente, no dia 12 de Dezembro de 2011) caracterizou a resposta 
educacional que foi disponibilizada às crianças portadoras do Síndrome X Frágil, no concelho de Alandroal, no periodo 1997-2007;

b) Elisabete Galhardas -É residente em Alandroal, trabalha, como Técnica Superior da Câmara Municipal de Alandroal e frequenta o Curso de Mestrado em Ciências da Educação (Especialização em Educação Comunitária). Na sua dissertação (já concluída e a aguardar marcação de data para defesa pública), realizou o estudo das aprendizagens disponibilizadas pelas instituições da freguesia de Nossa Senhora da Conceição (Alandroal), no periodo 1997-2007 [Entretanto, Elisabete Galhardas terminou o curso de Mestrado e encontra-se na fase final do projeto de tese doutoramento em Ciências da Educação, no qual prepara uma tese sobre os percursos de qualificação em Alandroal e a sua relação com os movimentos migratórios];

c) Margarida Grosso - Frequenta o Curso de Mestrado em Ciências da Educação (Especialização em Educação Comunitária). Na sua dissertação (já concluida e a aguardar marcação de data para defesa pública), realizou o estudo das aprendizagens disponibilizadas pelas instituições da freguesia de Santo António de Capelins (Alandroal), no período 1997-2007;

d) Cristina Barrenho - Frequenta o Curso de Mestrado em Ciências da Educação (Especialização em Administração Educacional). Na sua dissertação (já concluida e a aguardar marcação de data para defesa pública), pretende conhecer a realidade do insucesso escolar, no concelho de Alandroal, no periodo 1997-2007;

e) Carla Barreiros - Frequenta o Curso de Mestrado em Ciências da Educação (Especialização em Administração Educacional). Na sua dissertação (já concluida e a aguardar marcação de data para defesa pública), pretende conhecer a formação profissional disponibilizada e concretizada, no concelho de Alandroal, no periodo 1997-2007;

f) Gertrudes Sardinha - É Vice-Directora do Agrupamento de Escolas de Alandroal e frequenta o Curso de Mestrado em Ciências da Educação (Especialização em Administração Educacional). Na sua dissertação (em curso), pretende conhecer o perfil das aprendizagens formais, no concelho de Alandroal, no periodo 1997-2007;

g) Tomé Laranjinho - É Director do Agrupamento de Escolas de Alandroale frequenta o Curso de Mestrado em Ciências da Educação (Especialização em Administração Educacional). Na sua dissertação (em curso), pretende conhecer o perfil das aprendizagens não-formais, no concelho de Alandroal, no periodo 1997-2007;

h) Patrícia Maurício - Frequenta o Curso de Mestrado em Ciências da Educação (Especialização em Administração Escolar). Na sua dissertação (em curso), pretende conhecer o perfil das aprendizagens disponibilizadas pelas instituições da freguesia de Terena (São Pedro), no período 1997-2007. 
Uma das preocupações, sempre presente ao longo do período de concretização do projecto, consistiu na divulgação sistemática dos seus resultados, em quatro planos concomitantes:

G1. A divulgação científica, que se concretizou através da presença e participação de membros da equipa de investigação nos seguintes eventos e iniciativas:

a. I Seminário "Arqueologia" das Aprendizagens no concelho de Alandroal, realizado em Alandroal (Portugal), em 16 de Fevereiro de 2008;

b. VEncontro Regional de Educação/Aprender no Alentejo, realizado na Universidade de Évora (Évora/Portugal), em 5 e 6 de Junho de 2008;

c. X Congresso da Sociedade Portuguesa de Ciências da Educação, realizado no Instituto Superior Politécnico de Bragança (Bragança/Portugal), entre 30 de Abril e 2 de Maio de 2009;

d. X Congresso Internacional Galaico-Português de Psicopedagogia, realizado na Universidade do Minho (Braga/Portugal), entre 9 e 11 de Setembro de 2009;

e. I Fórum de Investigação em Ciências da Educação, realizado na Universidade de Lisboa (Lisboa/Portugal), entre 16 e 17 de Novembro de 2009;

f. II Seminário "Arqueologia" das Aprendizagens no concelho de Alandroal, realizado em Alandroal (Portugal), em 2 de Dezembro de 2009;

g. III Seminário "Arqueologia" das Aprendizagens no concelho de Alandroal, realizado em Alandroal (Portugal), em 9 de Maio de 2010;

h. IV Congreso IberoAmericano de Estudios Territoriales y Ambientales, realizado em Merida (Espanha), entre 27 e 29 de Maio de 2010;

i. 2nd Paris International Conference on Education, Economy \& Society, realizado em Paris (França), entre 21 e 24 de Julho de 2010;

j. IV Seminário Vozes da Educação: formação de professores/as - narrativas, politicas e memórias, realizado na Universidade do Estado do Rio de Janeiro (Rio de Janeiro/Brasil), entre 30 de Agosto e 1 de Setembro de 2010;

k. II Congresso Internacional sobre Avaliação em Educação - Aprender ao Longo da Vida - contributos, perspectivas e questionamentos do currículo e da avaliação, realizado na Universidade do Minho (Braga) Portugal), entre 4 e 6 de Novembro de 2010;

1. VI Encontro Regional de Educação/Aprender no Alentejo, realizado na Universidade de Évora (Évora/Portugal), em 19 e 20 de Novembro de 2010;

m. X Congresso da Sociedade Portuguesa de Ciências da Educação, realizado no Instituto Superior Politécnico da Guarda (Guarda/Portugal), entre 30 de Junho e 2 de Julho de 2011;

n. XI Congresso Internacional Galaico-Português de Psicopedagogia, realizado na Universidade da Corunha (La Corunha/Espanha), entre 7 e 9 de Setembro de 2011; 
o. IV Seminário Arqueologia da Aprendizagem no concelho de Alandroal, realizado em Alandroal, em 26 de Novembro de 2011.

G2. A divulgação através da publicação em edições de âmbito científico, académico ou comercial:

G3. A divulgação na comunicação social dos resultados, através da comunicação social, particularmente através do parceiro institucional Diário do SUL e de outros órgãos de comunicação social.

G4. A divulgação local dos resultados, através da realização de reuniões de trabalho ou de Seminários no concelho de Alandroal, o que aconteceu com periodicidade semestral, ao longo do periodo de concretização do projecto e que se verificou, nos seguintes momentos:

a) I Seminário do projecto Arqueologia das Aprendizagens no concelho de Alandroal, ocorrido em 13 de Fevereiro de 2008;

b) II Seminário do projecto Arqueologia das Aprendizagens no concelho de Alandroal, ocorrido em 16 de Fevereiro de 2009;

c) $V$ Encontro Regional de Educação/Aprender no Alentejo, realizado na Universidade de Évora, em 19 e 20 de Novembro de 2010;

d) III Seminário do projecto Arqueologia das Aprendizagens no concelho de Alandroal, ocorrido em 10 de Abril de 2010;

e) VI Encontro Regional de Educação/Aprender no Alentejo, realizado na Universidade de Évora, em 19 e 20 de Novembro de 2010;

f) IV Seminário do projecto Arqueologia das Aprendizagens no concelho de Alandroal, ocorrido em 27 de Novembro de 2011. Neste último seminário, foi divulgado o Livro "Arqueologia das Aprendizagens em Alandroal” (Nico, 2011) que incorpora os resultados finais do projecto. Esta publicação que foi distribuida por todos os participantes na iniciativa e disponibilizada a todas as instituições do concelho, particularmente as escolas, bibliotecas e associações da sociedade civil com responsabilidades na qualificação das pessoas.

G5. A divulgação interna dos resultados, no interior da parceria do projecto, o que se concretizou nos momentos previstos na calendarização inicial.

\section{H. OUTROS RESULTADOS DO PROJECTO}

\section{H.1. Abertura de uma nova Escola em Alandroal}

Um dos produtos, não previstos, inicialmente, do presente projecto de investigação consistiu na abertura de uma nova Escola em Alandroal: o pólo de Alandroal da Escola Popular da Universidade de Évora, o que aconteceu em 21 de Novembro de 2010. Esta nova escola, promovida através de uma parceria entre a Câmara Municipal de Alandroal e a Universidade de Évora, assumiu, desde o inicio, partir dos resultados decorrentes do projecto de investigação e das parcerias institucionais locais, no sentido de construir oportunidades de qualificação para a população adulta, através do aproveitamento das instituições da sociedade civil, da requalificação dos edifícios das escolas primárias, que se encontravam 
devolutas, e do envolvimento das Juntas de Freguesias do concelho. Actualmente, são mais de 100 os estudantes adultos desta escola em Alandroal e a mesma está presente nas freguesias de Alandroal (Nossa Senhora da Conceição), Terena (São Pedro) e Mina do Bugalho (São Brás dos Matos). Para o ano lectivo 2012/2013, prevê-se o alargamento às restantes freguesias do concelho. O novo Protocolo que a Câmara Municipal de Alandroal e a Universidade de Évora estabeleceram, no dia 27 de Novembro de 2011 (no decurso do IV Seminário do projecto Arqueologia das Aprendizagens em Alandroal), dá um impulso determinante na consolidação das actividades desta Escola Popular em Alandroal.

\section{H.2. Instalação de um Gabinete Local para trabalho científico em Alandroal}

Como já foi referido, anteriormente, em 2008, foi instalado, no Fórum Cultural Transfronteiriço de Alandroal, um Gabinete Local do projecto. Este espaço de trabalho científico tem estado a funcionar em permanência, desde aquela data, $e$ tem o seu futuro assegurado, através do novo protocolo celebrado entre a Câmara Municipal de Alandroal e a Universidade de Évora. A existência de trabalho cientifico regular, com um espaço dedicado e apetrechado com recursos técnicos e humanos qualificados é uma realidade inovadora e constitui uma valorização muito significativa para o concelho e para os seus quadros técnicos.

\section{H.3. Novo projecto em Alandroal.}

Na sequência da conclusão do actual projecto e no sentido de tornar úteis os respectivos resultados, a Câmara Municipal de Alandroal e a Universidade de Évora decidiram manter a equipa de investigação no terreno e partir para uma nova fase do trabalho de cooperação. Assim sendo, foi celebrado, em 27 de Novembro de 2011, aquando da realização do IV e último Seminário do Projecto Arqueologia das Aprendizagens no concelho de Alandroal, um novo Protocolo entre as duas instituições, envolvendo um financiamento de $46494 € e$ um novo calendário de trabalho até 30 de Junho de 2013.

\section{H.4. Réplica do projecto noutros territórios da Região Alentejo}

Com o desenvolvimento do projecto e da respectiva divulgação nos meios académicos e na comunicação social, ocorreram manifestações de interesse de outras Câmaras Municipais da região Alentejo, no sentido de se replicar, nos seus territórios, o estudo em curso em Alandroal. Foi o caso dos municípios de Viana do Alentejo, Portel e Gavião. Nos primeiros dois, a réplica do estudo está a acontecer, através da celebração de protocolos formais entre as respectivas Câmaras Municipais e a Universidade de Évora. Em Viana do Alentejo e Gavião, através da realização de projectos de doutoramento, por parte de estudantes do Curso de Doutoramento da Universidade de Évora e pertencentes à equipa de investigação do Centro de Investigação em Educação e Psicologia da Universidade de Évora. 


\subsection{A transferência do conhecimento para o território}

Em simultâneo e após a conclusão do projeto de investigação científica, anteriormente descrito, foi sendo desenhado e concretizado um processo de transferência do conhecimento para o território e as suas instituições. Dentro deste quadro, privilegiaram-se as atividades de extensão, de que se destacam as seguintes:

\subsubsection{A criação do Polo de Alandroal da Universidade Popular Túlio Espanca/Universidade de Évora}

Em 2010, foi criado o Polo da UPTE/UÉ em Alandroal, como consequência do trabalho de investigação científica realizado e no sentido de esta nova escola poder assumir-se como um projeto através do qual a Universidade de Évora e o Município de Alandroal continuariam a cooperar, na área da Educação, cruzando, sempre que possível, as fileiras da investigação científica e da formação académicas, num contexto territorial e culturalmente determinado.

Ao longo dos seus oito anos de existência, o Polo de Alandroal da UPTE/ UÉ tem vindo a promover atividades de educação não formal e popular, de perfil intergeracional, tendo, para o efeito, recorrido, sempre que foi possível, a instalações de escolas do primeiro ciclo do ensino básico que, entretanto, haviam sido descontinuadas.

A coordenação operacional do Polo de Alandroal tem estado, nos últimos anos, entregue a uma estudante do Programa de Doutoramento em Ciências da Educação da Universidade de Évora, Elisabete Galhardas (Mestre em Ciências da Educação - Educação Comunitária) e, nas atividades do mesmo, têm participado alguns estudantes de diversos cursos da academia eborense residentes no território.

\subsubsection{A nova Carta Educativa de Alandroal}

Após a conclusão do projeto de investigação científica «Arqueologia das Aprendizagens no concelho de Alandroal», verificou-se que a riqueza do território, em termos de contextos educativos institucionais assumia tal importância que seria crítico proceder ao recenseamento das instituições com potencial educativo e das respetivas atividades educativas e disponibilizar essa informação no principal documento formal de gestão local da Educação e que retrata a realidade educativa do território: a Carta Educativa.

Assim sendo, foi estabelecido um novo protocolo entre a Universidade de Évora e a Câmara Municipal de Alandroal, através do qual se assumiu a finalidade de proceder à revisão da Carta Educativa do concelho, atualizando a informação relativa à dimensão da educação formal e escolar e acrescentando-lhe a dimensão da educação não formal, decorrente 
do estudo realizado e a completar, junto das instituições não escolares com potencial educativo.

Este projeto terminou em 2013, após dois anos de trabalho no terreno, e dele resultou o referido documento e uma publicação «Atlas da Educação em Alandroal» (Nico, 2013), dedicado à divulgação do mapa completo da educação não formal do concelho.

Transcreve-se, em seguida, a Introdução desse livro, a qual evidencia, de forma clara, o percurso realizado e a importância, para o território e para a academia, do trabalho de revisão da Carta Educativa de Alandroal:

Desde 2002 que, em Alandroal, se iniciou um caminho de cooperação entre diversos actores institucionais e pessoais com responsabilidades na qualificação. Nessa data, a Câmara Municipal de Alandroal e a Universidade de Évora constituíram uma parceria formal, através da qual se iniciou, então, um projecto de investigação que resultou numa tese de doutoramento. Neste momento fundador, já se encontravam presentes as marcas estruturais do que viria a ser o maior projecto de investigação e intervenção em curso num municipio alentejano, no âmbito da educação e da formação, nas últimas décadas. Na realidade, desde a primeira hora, o território de Alandroal não foi considerado, simplesmente, o contexto físico e geográfico, mas foi assumido como a mais importante e decisiva variável da equação educacional do concelho. Um território dinâmico, no qual coabitam dimensões distintas, mas, concomitantemente, complementares e interdependentes: a geografia, a orografia, o clima, os recursos naturais geológicos e biológicos, a demografia, o ordenamento urbano, as vias de comunicação e os sistemas de transportes, as instituições da sociedade civil e respectivas redes, o património edificado e imaterial, as culturas locais, as tradições, os rituais religiosos e pagãos, os ecossistemas humanos e comunitários, as rotinas de vida, as actividades económicas e as empresas, os contextos formais e não formais de aprendizagem e, finalmente, as pessoas, suas famílias, seus quotidianos, suas trajectórias vitais e os seus projectos de futuro. Tudo isto constitui a riqueza extraordinária de cada território e é neste, complexo, dinâmico e evolutivo, contexto territorial que acontece a educação das pessoas. Ignorar esta complexidade desliga a educação dos contextos de vida das pessoas e torna-a num acontecimento vital isolado e redutor. Foi com este pensamento que o caminho se iniciou e que, hoje, se continua a trilhar. Mais tarde, em 2007, no âmbito do projecto "Arqueologia das Aprendizagens no concelho de Alandroal" - promovido pelo Centro de Educação e Psicologia da Universidade de Évora, financiado pela Fundação para a Ciência e a Tecnologia (FCT) e apoiado pela Câmara Municipal de Alandroal - ocorreu um importante impulso para a consolidação do pensamento e consequente intervenção na realidade. 
Com esse projecto, foi criado, no Fórum Cultural Transfronteiriço de Alandroal, um Gabinete Local de Investigação, que, desde essa data, tem acolhido a equipa de pesquisa da Universidade de Évora, que tem sido sempre integrada por investigadores de ambas as instituições. Este projecto, concluido em 2011, resultou num conjunto significativo de estudos académicos sobre a realidade alandroalense: 2 teses de doutoramento, 5 dissertações de mestrado, 2 livros, 4 artigos em revistas cientificas, 10 comunicações em congressos, 6 seminários científicos, 6 relatórios e 7 encartes de divulgação científica em órgãos de comunicação social regional (Nico, 2011). Na sequência da concretização de todos os projectos de pesquisa concretizados no âmbito da educação e da formação, no concelho de Alandroal e de todo o conhecimento por eles produzido e disponibilizado, encontra-se, na actualidade, disponivel um, extenso, objectivo e actual, corpo de conhecimentos acerca da realidade educacional do território, nas suas diversas dimensões. De facto, nos últimos quatro anos, foi inquirida a quase totalidade do universo de instituições existentes e em actividade no concelho e uma amostra significativa da população nele residente. Por outro lado, a informação recentemente disponibilizada pelo Recenseamento Geral da População - realizado em 2011, pelo Instituto Nacional de Estatística (INE, 2012) - e a informação existente nos diferentes documentos de gestão política local - de que o Plano de Desenvolvimento Social do concelho de Alandroal (CMA, 2007) é um exemplo, a Agenda XXI ou o Plano Director Municipal, na sua versão de 2006 - produzidos pela autarquia local, proporcionam um bom conhecimento da realidade demográfica, social e económica alandroalense, em muitas das dimensões relevantes para o processo de Revisão da Carta Educativa. Nestas condições e atendendo ao facto de a actual Carta Educativa de Alandroal se reportar a uma realidade existente em 2006, encontram-se reunidas boas condições para se proceder à revisão desse importante documento, na sua dimensão fundamental - a dimensão da educação escolar, respectivas infraestruturas físicas e população escolar - e no seu perímetro conceptual, institucional e estratégico, incluindo, no seu seio, a dimensão não-escolar e as instituições da sociedade civil com papel relevante na qualificação da população, em todos os momentos da sua vida e o necessário encontro entre a qualificação, a economia e o desenvolvimento. Estamos, pois, na fase final deste terceiro momento de trabalho científico e técnico no concelho de Alandroal: a apresentação da nova Carta Educativa de Alandroal, pensada, estruturada e desenhada com base nos seguintes pressupostos:

1. A Educação acontece num contexto territorial determinado e específico, de acordo com a complexidade determinada por um conjunto de variáveis que também, aí, assume características determinadas e especificas; 
2. A Educação acontece em todos os espaços e tempos da vida das pessoas e não é exclusiva dos contextos escolares e formais;

3. Em territórios rurais, do interior do pais e marcados por demografias envelhecidas e muito sedentarizadas, a Educação das pessoas encontra-se muito estreitamente relacionada com a dimensão comunitária de proximidade, as instituições locais e respectivas redes, os laços familiares e de vizinhança, os contextos profissionais e os ambientes pessoais de socialização e convívio;

4. O acesso e a capacidade de manter uma frequência de aprendizagem, activa e regular, em contextos formais e escolares de Educação são inversamente proporcional com a idade e a distância aos centros urbanos de maior dimensão, facto que determina desigualdade territorial e pessoal;

5. A Educação e a Economia encontram frágeis e pouco frequentes mecanismos de diálogo e de cooperação estratégica, com consequências ao nivel das expectativas de realização vocacional profissional das pessoas e de pouca qualificação do trabalho, no âmbito das empresas;

6. O diálogo e o trabalho cooperativo entre as instituições da sociedade civil é pouco frequente e entre estas e as escolas há um campo que possui um enorme potencial de desenvolvimento, atendendo à riqueza do contexto territorial, como recurso curricular e didáctico para as aprendizagens escolares e levando em conta o potencial das escolas para a promoção do acesso à Educação, por parte da população adulta pouco escolarizada;

7. A Carta Educativa não pode nem deve circunscrever-se ao perímetro da Educação Escolar. Deve conter todo o contexto territorial e institucional, incluindo todos os tempos e espaços de aprendizagem disponíveis no território com potencial educativo e com capacidade de articulação e cooperação com os dispositivos e modalidades da educação formal;

8. A Carta Educativa deve assumir o desenvolvimento do território e da população nele residente, como a sua bússola, assumindo a Educação e a Formação como o mais poderoso e eficaz instrumento de promoção desse desenvolvimento, de forma sustentada e participada;

9. A Carta Educativa deve dialogar, permanente e activamente, com os restantes instrumentos de gestão politica local: Plano Director Municipal, Plano de Desenvolvimento Social, Agenda XXI, entre outros;

10. A Carta Educativa deve ser um instrumento dinâmico, em constante actualização e disponivel, em cada momento, contendo a informação necessária para se promoverem o máximo de oportunidades de qualificação, dirigidas ao maior número possivel de pessoas e instituições, com a maior eficácia e eficiência possíveis, mobilizando o maior número de recursos locais e envolvendo o menor esforço financeiro possiveis. Por outras palavras, a Carta Educativa deve indicar como concretizar a Qualificação, num determinado território, com a maior amplitude 
humana e institucional, a máxima eficiência e eficácia do investimento e o mais forte impulso de desenvolvimento humano, social e económico. Foi com esta bússola que iniciámos, em 2002, esta caminhada científica no território de Alandroal. O presente livro “Atlas da Educação em Alandroal" - concebido e produzido no âmbito do projecto de revisão da Carta Educativa de Alandroal, que decorreu entre Fevereiro de 2012 e Julho de 2013 - apresenta uma parte desse mapa que, ao longo desta última década, temos vindo a construir, particularmente a cartografia que temos vindo a elaborar desse extraordinário mundo da educação nas escolas fora da escola. (Nico, 2013: 7-11)

No presente, mantém-se a cooperação entre a Universidade de Évora e o município de Alandroal, através do Polo da UPTE/UÉ e este exemplo está a ser replicado no município de Portel, onde se está a ocorrer a revisão e complemento da Carta Educativa, utilizando o caso de Alandroal, como referência. 


\section{CAPÍTULO 4}

\section{O PROJETO «CURRÍCULO, EDUCAÇÃO POPULARE RESPONSABILIDADE SOCIAL NA UNIVERSIDADE»}

\subsection{O ENQUADRAMENTO DO PROJETO}

Apresentam-se, nas páginas seguintes, algumas das atividades do projeto «Currículo, Educação Popular e Responsabilidade Social na Universidade», referido anteriormente e no âmbito do qual, se concretizaram atividades de extensão universitária, com as quais se promoveu a interação com a investigação científica e, principalmente, com a formação graduada e pós-graduada da Universidade de Évora, em particular na área científica das Ciências da Educação.

Transcreve-se, em seguida, algum do conteúdo do anexo técnico da candidatura apresentada à Fundação Calouste Gulbenkian (Nico, 2016: 4-7):

O presente projeto assume, como finalidade, proporcionar, aos estudantes da Universidade de Évora (UÉ), no âmbito da missão desta, oportunidades de concretizarem a sua responsabilidade social individual e a da instituição a que pertencem, concebendo, planificando e concretizando projetos de educação não formal abertos à participação da população do Alentejo, decorrentes da mobilização do conhecimento e das competências cientifica, cultural, técnica e tecnológica da respetiva formação curricular formal e enquadrados, sempre que possivel, pelos seus docentes, no âmbito dos planeamentos didáticos das unidades curriculares existentes e na atividade educacional da Universidade Popular Túlio Espanca e dos seus pólos localizados na região.

Neste contexto, o projeto aposta em convocar as aprendizagens concretizadas no âmbito curricular das diferentes formações da Universidade de Évora para o esforço de promoção de oportunidades de aprendizagem de natureza não formal $e$ de divulgação científica e cultural dirigidas às comunidades locais de onde são originários os estudantes envolvidos. 
Simultaneamente, concretiza a missão, institucional e estatutária, da Universidade de Évora: a produção do conhecimento, a formação superior e o serviço à comunidade, neste caso, através de projetos de extensão educacional inscritos no conceito de ALV (Aprendizagem ao Longo da Vida), nas diferentes áreas científicas presentes na academia e que são frequentadas pelos estudantes a envolver.

O presente projeto permitirá consolidar, na academia e na região Alentejo, um modelo pedagógico e curricular socialmente responsável e assente no pressuposto de que, em contexto académico, é possível e qualitativamente vantajoso para a qualidade $e$ dimensão social e cívica das aprendizagens, a participação discente em projetos de divulgação e promoção científicas, nos quais, se mobilizam e aplicam, em contexto real de educação popular nas comunidades de origem dos discentes, os conhecimentos e as competências edificados, curricular $e$ formalmente, na academia. Por outro lado, a certificação desta participação, em complementaridade com a certificação académica tradicional, diferenciará o CV dos estudantes participantes, porque o enriquecerá com competências habitualmente ausentes dos currículos académicos mas atualmente muito valorizadas em contextos profissionais (Nico \& Costa, 2004).

A participação de professores e estudantes no presente projeto, através da construção e concretização de janelas curriculares de educação popular concretizará uma outra dimensão institucional das universidades: a responsabilidade social. Na realidade, a transferência, para a sociedade, dos conhecimentos e das capacidades construidas nas salas de aula, nos laboratórios ou nos ateliers universitários, possibilitará a criação de uma diferente percepção da utilidade do conhecimento, do seu papel no exercício da cidadania e da relevância que o mesmo pode desempenhar na coesão social. Simetricamente, poderá ocorrer uma diferente leitura do trabalho educativo realizado pelas universidades, por parte dos participantes nestes projetos.

o papel dos órgãos de comunicação social, nesta dimensão, será crítico, atendendo ao seu poder de divulgação junto de toda a sociedade. Nesse sentido, a participação do grupo de comunicação social Diário do SUL (parceiro fundador da Universidade Popular Túlio Espanca) é uma variável importante, atendendo à capacidade de divulgação dos diferentes meios de comunicação ao dispor deste parceiro (jornal, radio, web TV e plataformas eletrónicas) e consequente reconhecimento e certificação social dos seus participantes. Pensamos que, desta forma, a Universidade cumprirá, de forma mais ativa, qualificada $e$ 


\begin{abstract}
participada, o seu papel de Responsabilidade Social, como a instituição mais qualificada do território local e regional e como centro, por excelência, produtor e difusor do conhecimento e da cultura (Nico et al, 2015a, 2015b).
\end{abstract}

\title{
1.1. A dimensão científica e pedagógica
}

Como foi referido em candidatura anteriormente apresentada, a Universidade de Évora (através da Universidade Popular Túlio Espanca) e a equipa de investigação desta candidatura têm assumido as questões da Educação Popular e do papel da academia nesse esforço, permanente e socialmente responsável, de criação e qualificação de oportunidades para o exercício do Direito à Educação [Nico (1996, 1999, 2001a, 2011b, 2002), Nico, L. (2011), Nico \& Nico (2011), Nico (2015), Nico et al (2015a), Nico et al (2015b)], como um dos vetores mais estruturais e visiveis da concretização da missão estatutária da instituição e do exercício da sua responsabilidade social junto do território e das comunidades locais nele existentes.

Anteriores projetos de investigação e de intervenção promovidos pelo Centro de Investigação em Educação e Psicologia da Universidade de Évora (CIEP/UÉ) e pela Universidade Popular Túlio Espanca (UPTE), financiados pela Fundação para a Ciência e a Tecnologia (FCT) e pela Fundação Calouste Gulbenkian (FCG), desenvolvidos por equipas de investigação que contaram com a generalidade dos membros da equipa do presente projeto e coordenados pelo Investigador Responsável e Coordenador da presente candidatura, Prof. José Bravo Nico, têm dado concretização, científica, pedagógica e de extensão universitária, aos princípios indicados [Nico \& Nico (2015)]:

a) projeto "Arqueologia das Aprendizagens no concelho de Alandroal"/ Ref ${ }^{\text {F }}$ FCT/PTDC/CED/81388/2006, iniciado em 2 de Novembro de 2007 e concluído em 31 de Outubro de 2011). Deste projeto - promovido pelo CIEP e financiado pela FCT e que envolveu estudantes de licenciatura e de mestrado da Universidade de Évora - resultaram, entre outros produtos, a criação do Pólo de Alandroal da UPTE, que, na atualidade, acolhe $e$ dinamiza a participação de mais de 500 cidadãos daquele concelho do Alentejo (Nico, 2011; Nico et al, 2013) em atividades educativas de natureza não formal. O mesmo aconteceu, na sede da UPTE, em Évora nos Pólos de Viana do Alentejo e de Portel e, também, na Escola Comunitária de São Miguel de Machede, parceira da UPTE, desde a sua fundação;

b) projeto "As novas Núpcias da qualificação no Alentejo"/refa FCT/ PTDC/ CPE-CED/104072/2008, iniciado em 1 de Junho de 2010 e concluído em 31 de Maio de 2013). Este projeto - promovido pelo CIEP e financiado pela FCT e que envolveu estudantes de licenciatura e de mestrado da UÉproporcionou uma leitura ampla do espectro de qualificação da população alentejana que, na última década, realizou percursos de aprendizageme de certificação de adquiridos experienciais, no âmbito dos dispositivos de 
Educação e Formação de Adultos disponíveis. Esta informação (Nico et al, 2012) foi muito útil para o desenho e planificação de novos dispositivos de educação não formal em formato de educação popular e para a conceção e concretização do projeto que, a seguir se indica (Nico, L. (2011); Nico et al (2012);

c) Projeto «Janelas Curriculares de Educação Popular no Ensino Superior Universitário". Este projeto - promovido pela UPTE, financiado pela FCG e com forte envolvimento de discentes e docentes da UÉ - iniciou-se em Junho de 2014 e terminará em Junho de 2016. A presente candidatura pretende aproveitar os resultados deste projeto, consolidando o modelo pedagógico da UPTE e alargando, de forma estruturada e territorialmente adaptada, a participação discente e docente [(Nico et al (2015a), Nico et al (2015b)].

\subsection{A dimensão metodológica}

O projeto assume que a Universidade Túlio Espanca constitui-se como um recurso didático disponivel para a valorização das aprendizagens dos estudantes, oportunidade privilegiada para a socialização do conhecimento científico e cultural produzido e ensinado na Universidade de Évora e um instrumento adequado para a concretização da responsabilidade social da academia, junto da região Alentejo e das comunidades locais aí residentes [Nico, B. (2002, 2012), Nico, B. \& Costa, E. (2004), Nico, B. \& Nico, L. (2012a, 2012b) Nico, B. et al, (2015a), Nico, B et al (2015b)].

\subsection{0 timeline do projeto}

O projeto desenvolveu-se durante dois anos letivos (2016/2017 e 2017/2018).

Entre 15 de Julho e 31 de Agosto de 2018, concretizou-se a avaliação final do projeto e a elaboração do respetivo Relatório Final.

\subsection{Os parceiros do projeto}

Foram parceiros deste projeto as seguintes instituições:

(i) Diário do SUL: grupo de comunicação social regional, que conta com um jornal (Diário do SUL), uma rádio (Rádio Telefonia do Alentejo) e uma webTV (http://Kanal.pt/643891). Parceiro de longa data em projetos da equipa de investigação e da própria Universidade Popular Túlio Espanca, desde o seu início (2009), o Diário do SUL constituiu-se como o media partner e teve a responsabilidade de divulgação e socialização do projeto, das atividades nele inscritas e dos respectivos resultados.

(ii) Escola Comunitária de São Miguel de Machede/ Suão-Associação de Desenvolvimento Comunitário: instituição vocacionada para a 
Educação não Formal e localizada numa das freguesias do concelho de Évora (São Miguel de Machede). No âmbito do seu projeto, a Escola Comunitária de São Miguel de Machede desenvolve, desde 1998, atividades educativas de âmbito popular em contextos não formais e intergeracionais de aprendizagem, nos quais, frequentemente, participam estudantes universitários voluntários. Tal como o Diário do SUL, a Escola Comunitária de São Miguel de Machede é parceira de longa data nos projetos desenvolvidos pela equipa de investigação da própria UPTE/UÉ, contribuindo com a sua experiência e os seus recursos físicos, didáticos e, principalmente, humanos.

\subsection{Descritivo das atividades concretizadas no projeto}

O início do projeto coincidiu com o arranque das atividades/aulas, no ano letivo 2016/2017, na Universidade de Évora. Como anteriormente, a equipa de investigadores da UPTE/UÉ divulgou o projeto junto dos alunos e docentes da Universidade de Évora, que mostraram disponibilidade para participar neste mesmo. Descrevem-se, de seguida, as atividades planeadas e concretizadas, no decorrer dos dois anos letivos referidos, organizadas em 6 categorias, conforme se apresenta no Quadro 1.

\begin{tabular}{|c|c|c|c|}
\hline & oria & $\begin{array}{l}\text { Natureza das Jane- } \\
\text { las Curriculares }\end{array}$ & Descritivo da Janela Curricular \\
\hline \multirow{4}{*}{ 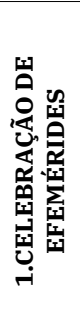 } & \multirow{4}{*}{ 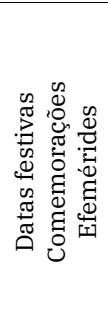 } & \multirow{2}{*}{$\begin{array}{l}\text { Dinamizado pela } \\
\text { UPTE/UÉ }\end{array}$} & $\begin{array}{l}\text { Dia da Universidade Popular Túlio Espanca } \\
\text { da Universidade de Évora/2017 }\end{array}$ \\
\hline & & & $\begin{array}{l}\text { Dia da Universidade Popular Túlio Espanca } \\
\text { da Universidade de Évora/2018 }\end{array}$ \\
\hline & & $\begin{array}{l}\text { Dinamizado pelos } \\
\text { Polos da UPTE/UÉ }\end{array}$ & $\begin{array}{l}\text { Comemoração do } 2 .^{\circ} \text { aniversário de atividade } \\
\text { do Polo de Canaviais/Évora }\end{array}$ \\
\hline & & Outras Atividades & $\begin{array}{l}\text { Participação da UPTE no Dia da Universidade } \\
\text { de Évora/2017 }\end{array}$ \\
\hline \multirow{5}{*}{ 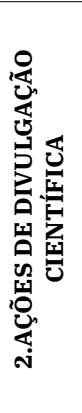 } & \multirow{5}{*}{ 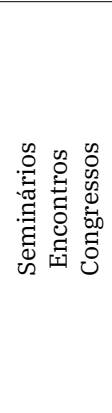 } & \multirow{2}{*}{$\begin{array}{l}\text { Organizados pela } \\
\text { UPTE/UÉ (com a } \\
\text { colaboração de } \\
\text { estudantes) }\end{array}$} & $\begin{array}{l}\text { 2.1. I Encontro de Educação Popular na } \\
\text { Universidade de Évora }\end{array}$ \\
\hline & & & $\begin{array}{l}\text { 2.2. IX Aprender no Alentejo - Encontro } \\
\text { Regional de Educação }\end{array}$ \\
\hline & & \multirow{2}{*}{$\begin{array}{l}\text { Participação da } \\
\text { equipa da UPTE/UÉ } \\
\text { em eventos científicos } \\
\text { nacionais }\end{array}$} & $\begin{array}{l}\text { 2.3 Fórum sobre o tema "Alfabetizar no séc.XXI } \\
\text { - o novo paradigma de alfabetização solidária" }\end{array}$ \\
\hline & & & $\begin{array}{l}\text { 2.4. IV Seminário Nacional de Educação e } \\
\text { Formação de Adultos }\end{array}$ \\
\hline & & $\begin{array}{l}\text { Participação da } \\
\text { equipa da UPTE/UÉ } \\
\text { em eventos cientificos } \\
\text { internacionais }\end{array}$ & $\begin{array}{l}\text { 2.5. XIV Congresso Internacional Galego-Por- } \\
\text { tuguês de Psicopedagogia }\end{array}$ \\
\hline
\end{tabular}




\begin{tabular}{|c|c|c|c|}
\hline \multirow{3}{*}{ 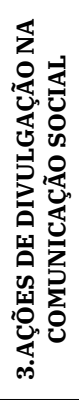 } & \multirow{3}{*}{ 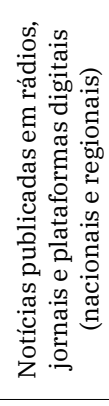 } & $\begin{array}{l}\text { Nos meios de } \\
\text { comunicação social } \\
\text { nacionais }\end{array}$ & 3.1. Jornal Público \\
\hline & & $\begin{array}{l}\text { Nos meios de } \\
\text { comunicação social } \\
\text { regionais }\end{array}$ & $\begin{array}{l}3.2 . \\
\text { Rádio Pax } \\
\text { Diário do Alentejo } \\
\text { Diário do Sul } \\
\text { Rádio Campanário }\end{array}$ \\
\hline & & $\begin{array}{l}\text { Página Web e rede } \\
\text { social da UPTE/UÉ }\end{array}$ & $\begin{array}{l}\text { 3.3. } \\
\text { Universidade Popular Túlio Espanca/UÉ } \\
\text { Autarquias parceiras/Pólos da UPTE/UÉ } \\
\text { Diário do Sul }\end{array}$ \\
\hline \multirow{3}{*}{ 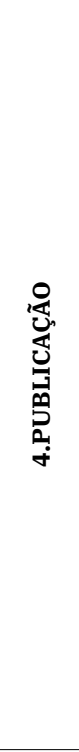 } & \multirow{3}{*}{ 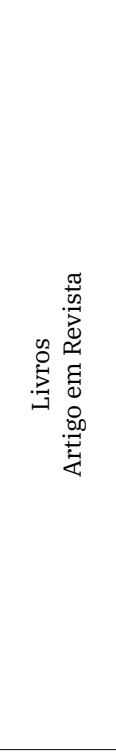 } & $\begin{array}{l}\text { Livro } \\
\text { Resultante do projeto } \\
\text { desenvolvido pela } \\
\text { UPTE e financiado } \\
\text { pela Fundação } \\
\text { Calouste Gulbenkian } \\
\text { “Janelas Curriculares } \\
\text { de Educação Popular } \\
\text { no Ensino Superior } \\
\text { Universitário" }\end{array}$ & $\begin{array}{l}\text { 4.1. Apresentação pública do Livro «Janelas } \\
\text { Curriculares de Educação Popular na Universidade } \\
\text { de Évora: para um conhecimento académico mais } \\
\text { humanista e solidário» } \\
\text { (Nico \& Nico, 2016a) }\end{array}$ \\
\hline & & $\begin{array}{l}\text { Livro } \\
\text { Atas do VIII Encontro } \\
\text { Regional de Educação } \\
\text { "Aprender no } \\
\text { Alentejo" }\end{array}$ & $\begin{array}{l}\text { 4.2.Pública do Livro «Didáticas do Alentejo» } \\
\text { (participação dos estudantes da Licenciatura } \\
\text { em Ciências da Educação) } \\
\text { (Nico \& Nico, 2016b) }\end{array}$ \\
\hline & & $\begin{array}{l}\text { Publicação de Artigo } \\
\text { em Revista com } \\
\text { Arbitragem Científica }\end{array}$ & $\begin{array}{l}\text { 4.3.NICO, Bravo \& NICO, Lurdes (2017). Cur- } \\
\text { rículo, Educação Popular e Responsabilidade } \\
\text { Social na Universidade de Évora: para um } \\
\text { conhecimento académico mais humanista } \\
\text { e solidário. Revista de Estudios e Investigación } \\
\text { em Psicología Y Educación, vol. Extra, (10) / } \\
\text { ISSN 2386-7418 / https://doi.org/10.17979/ } \\
\text { reipe.2017.0.10.2650 }\end{array}$ \\
\hline \multirow{3}{*}{ 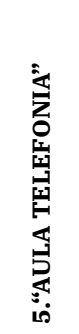 } & \multirow{3}{*}{ 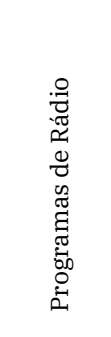 } & Aula Telefonia 1 & 5.1. Tema: As Vacinas \\
\hline & & Aula Telefonia 2 & 5.2. Tema: A Arte Chocalheira de Alcáçovas \\
\hline & & Aula Telefonia 3 & 5.3. Tema: Os Sismos \\
\hline
\end{tabular}




\begin{tabular}{|c|c|c|c|}
\hline \multirow{13}{*}{ 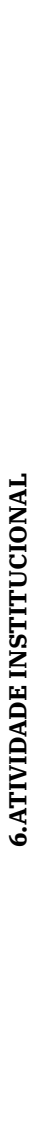 } & \multirow{5}{*}{ 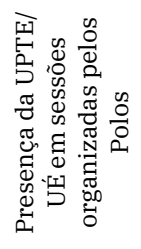 } & \multirow{2}{*}{$\begin{array}{l}\text { Sessão de abertura } \\
\text { formal das atividades }\end{array}$} & 6.1. Polo de Viana do Alentejo/2016 \\
\hline & & & 6.2. Polo de Canaviais/2017 \\
\hline & & & 6.3. Polo de Canaviais/2017 \\
\hline & & mento formal das & 6.4. Polo de Portel/2017 \\
\hline & & & 6.5. Polo de Canaviais/2018 \\
\hline & \multirow{6}{*}{ 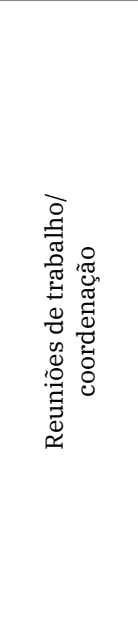 } & $\begin{array}{l}\text { Reunião de prepara- } \\
\text { ção da abertura do } \\
\text { Polo de Barrancos da } \\
\text { UPTE/UÉ em Viana } \\
\text { do Alentejo }\end{array}$ & $\begin{array}{l}\text { 6.6. Reunião entre a UPTE, o Polo de Viana do } \\
\text { Alentejo e o Município de Barrancos }\end{array}$ \\
\hline & & $\begin{array}{l}\text { Participação da } \\
\text { UPTE/UÉ em reunião } \\
\text { de trabalho }\end{array}$ & 6.7. Reunião em Lisboa \\
\hline & & $\begin{array}{l}\text { Reunião de prepara- } \\
\text { ção da abertura de } \\
\text { Polo de Reguengos de } \\
\text { Monsaraz }\end{array}$ & $\begin{array}{l}\text { 6.8. Reunião entre a UPTE/UÉ e o Município } \\
\text { de Reguengos de Monsaraz }\end{array}$ \\
\hline & & $\begin{array}{l}\text { Reunião com os Polos } \\
\text { - Balanço do ano }\end{array}$ & $\begin{array}{l}\text { 6.9. Reunião de trabalho entre os responsá- } \\
\text { veis da UPTE/UÉ; Cooordenadores e Técnicos } \\
\text { de cada Polo }\end{array}$ \\
\hline & & $\begin{array}{l}\text { Reuniões em cada um } \\
\text { dos Polos }\end{array}$ & $\begin{array}{l}\text { 6.10. Reuniões deslocalizadas em cada um } \\
\text { dos Polos }\end{array}$ \\
\hline & & $\begin{array}{l}\text { Reunião de Coorde- } \\
\text { nação Geral }\end{array}$ & $\begin{array}{l}\text { 6.11.Na Universidade de Évora, com a } \\
\text { presença dos Polos da UPTE/UÉ }\end{array}$ \\
\hline & \multirow{2}{*}{ 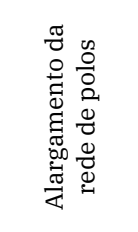 } & $\begin{array}{l}\text { Sessão pública de } \\
\text { assinatura do Proto- } \\
\text { colo em Barrancos }\end{array}$ & $\begin{array}{l}\text { 6.12. Abertura do Polo da UPTE/UÉ em } \\
\text { Barrancos }\end{array}$ \\
\hline & & $\begin{array}{l}\text { Sessão pública de } \\
\text { assinatura do Proto- } \\
\text { colo em Reguengos de } \\
\text { Monsaraz }\end{array}$ & $\begin{array}{l}\text { 6.13. Abertura do Polo da UPTE/UÉ em } \\
\text { Reguengos de Monsaraz }\end{array}$ \\
\hline
\end{tabular}

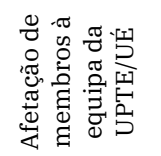

Contratação de uma Bolseira de 6.14. Função desempenhada por uma antiga aluna da Universidade de Évora, Licenciada em Ciências da Educação, Vanessa Sampaio

\begin{tabular}{|c|c|c|c|}
\hline \multirow{2}{*}{ 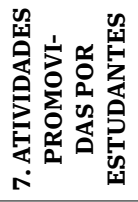 } & \multirow{2}{*}{ 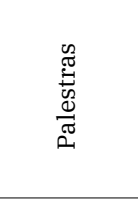 } & $\begin{array}{l}\text { Palestra } 1 \\
\text { Local: Viana do } \\
\text { Alentejo }\end{array}$ & $\begin{array}{l}\text { 7.1. Tema: Animais } \\
\text { “O que dizem os nossos cães?” }\end{array}$ \\
\hline & & $\begin{array}{l}\text { Palestra } 2 \\
\text { Local: São Miguel de } \\
\text { Machede }\end{array}$ & $\begin{array}{l}\text { 7.2. Tema: Culturas Portuguesa e Brasileira } \\
\text { "Jeitinho Brasileiro" }\end{array}$ \\
\hline \multirow{3}{*}{ 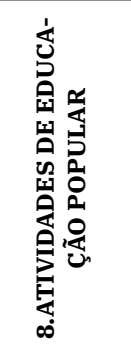 } & \multirow{3}{*}{ 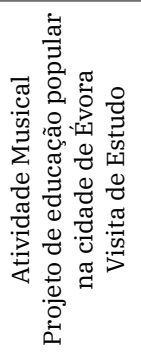 } & $\begin{array}{l}\text { Promovidas pelos } \\
\text { Polos }\end{array}$ & $\begin{array}{l}\text { 8.1. II Grande Audição da Escola de Música de } \\
\text { Hortinhas e atuação do Grupo “Trigueirão no } \\
\text { Relheiro“ }\end{array}$ \\
\hline & & & 8.2. Projeto "Escola da Cidade" \\
\hline & & $\begin{array}{l}\text { Promovidas pela } \\
\text { UPTE/UÉ }\end{array}$ & $\begin{array}{l}\text { 8.3. Visita de Estudo à Universidade de } \\
\text { Évora/2018 }\end{array}$ \\
\hline
\end{tabular}




\section{CELEBRAÇÃO DE EFEMÉRIDES}

\section{DINAMIZADO PELA UPTE/UÉ}

\subsection{Dia da Universidade Popular Túlio Espanca da Universidade de Évora/2017}

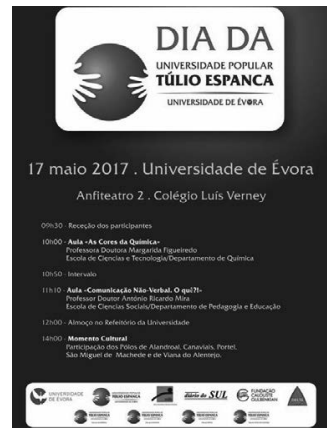

Figura 2 . Programa do Dia da Universidade Popular Túlio Espanca

Este ano, as atividades agendadas para a comemoração do Dia da Universidade Popular Túlio Espanca, decorreram no Colégio Luís Verney, na Universidade de Évora, em 17 de Maio de 2017.

A manhã foi dedicada a duas aulas preparadas por docentes da Universidade de Évora, nomeadamente:

10h - Aula "As Cores da Química»

Professora Doutora Margarida Figueiredo

(Escola de Ciências e Tecnologia/Departamento de Química)

11h10min - Aula "Comunicação Não-Verbal. O quê?!"

Professor Doutor António Ricardo Mira

(Escola de Ciências Sociais/Departamento de Pedagogia e Educação)

Após o almoço (no refeitório da Universidade), seguiu-se o momento cultural, com a participação dos Polos de Alandroal, Canaviais, Portel, São Miguel de Machede e de Viana do Alentejo.

A Senhora Reitora da Universidade de Évora, Prof. Doutora Ana Costa Freitas, referiu, a este propósito, o seguinte:

“(...) o trabalho desta Universidade é extremamente meritório, "hoje fala-se muito em envelhecimento ativo, com associação imediata à prática desportiva", mas este conceito "é mais abrangente: diz respeito a manter também a mente ativa, contribuindo assim para a manutenção de uma vida mais saudável, de forma integradacorpo e mente - e uma maior qualidade de vida", evidencia. De fato, o "conhecimento" e a "educação" são condições fundamentais 
para um "maior bem-estar" da sociedade, que "nos fazem viver cada dia de forma diferente”. Ciente da responsabilidade que uma "Universidade pública" deverá ter para com a sociedade, a Reitora da Academia alentejana, refere ser missão da UÉ, "levar a educação e o conhecimento a todos os segmentos da população", endereçado no final da sessão "os parabéns a todos os alunos da Universidade Túlio Espanca pelo entusiamo, pela recetividade".

(Fonte: http://www.uevora.pt/media_informacoes/noticias/ (item)/22323)

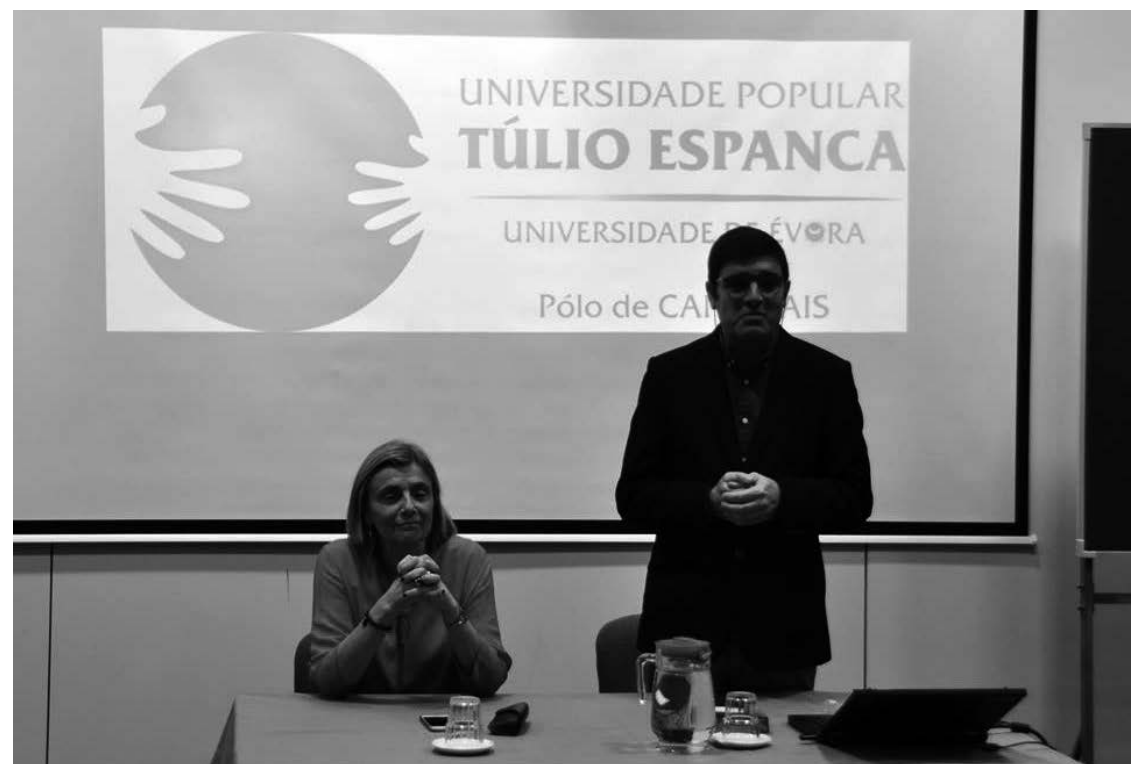

Figura 3. Presença da Senhora Reitora na receção do "Dia da Universidade Popular Túlio Espanca”

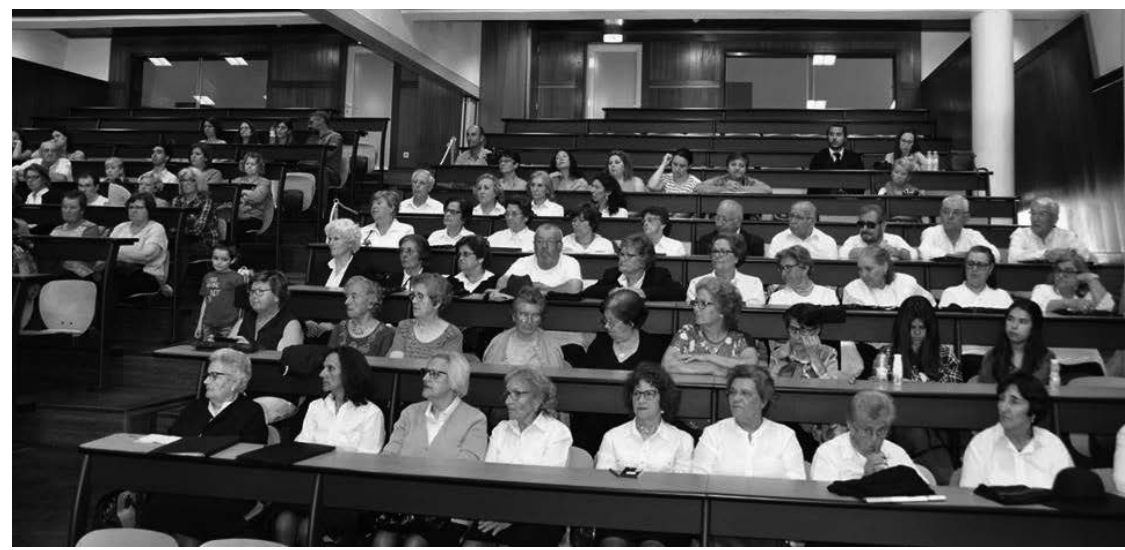

Figura 4. Participantes no “Dia da Universidade Popular Túlio Espanca 


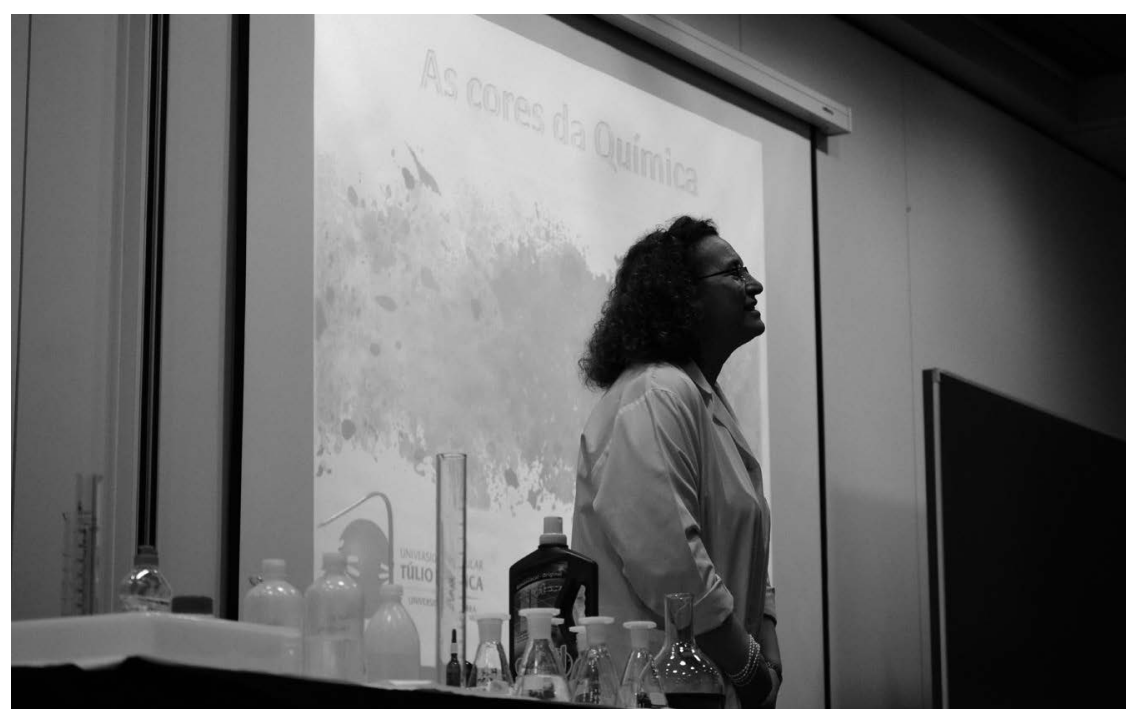

Figura 5. Aula «As Cores da Química»

Professora Doutora Margarida Figueiredo (Escola de Ciências e Tecnologia/Departamento de Química)

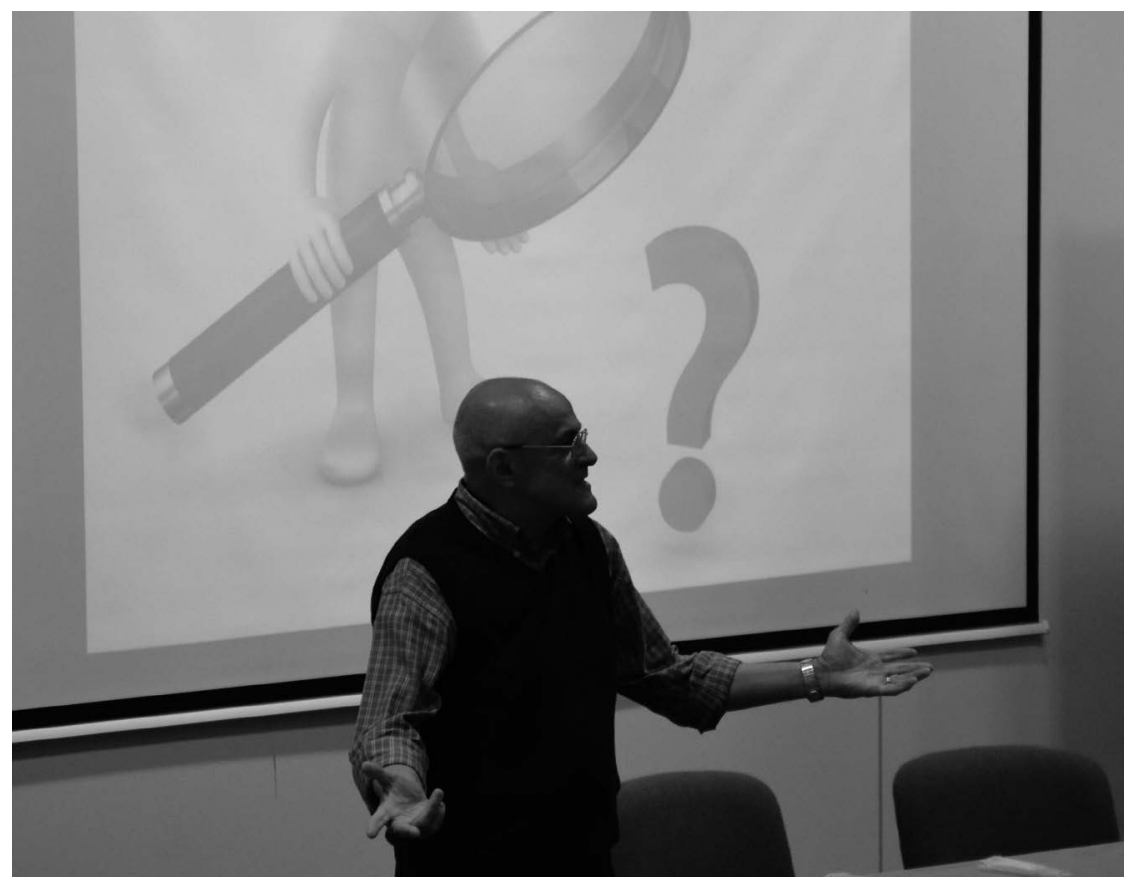

Figura 6. Aula «Comunicação Não-Verbal. o quê?!»

Professor Doutor António Ricardo Mira(Escola de Ciências Sociais/Departamento de Pedagogia e Educação) 


\section{DINAMIZADO PELA UPTE/UÉ}

\subsection{Dia da Universidade Popular Túlio Espanca da Universidade de Évora/2018}

Em 15 de Maio de 2018, comemorou-se o Dia da UPTE/UÉ 2018.Esta atividade integrou o cartaz do Ciclo de Iniciativas do Curso da Licenciatura em Ciências da Educação, uma vez que os estudantes participaram na organização e dinamização da atividade.

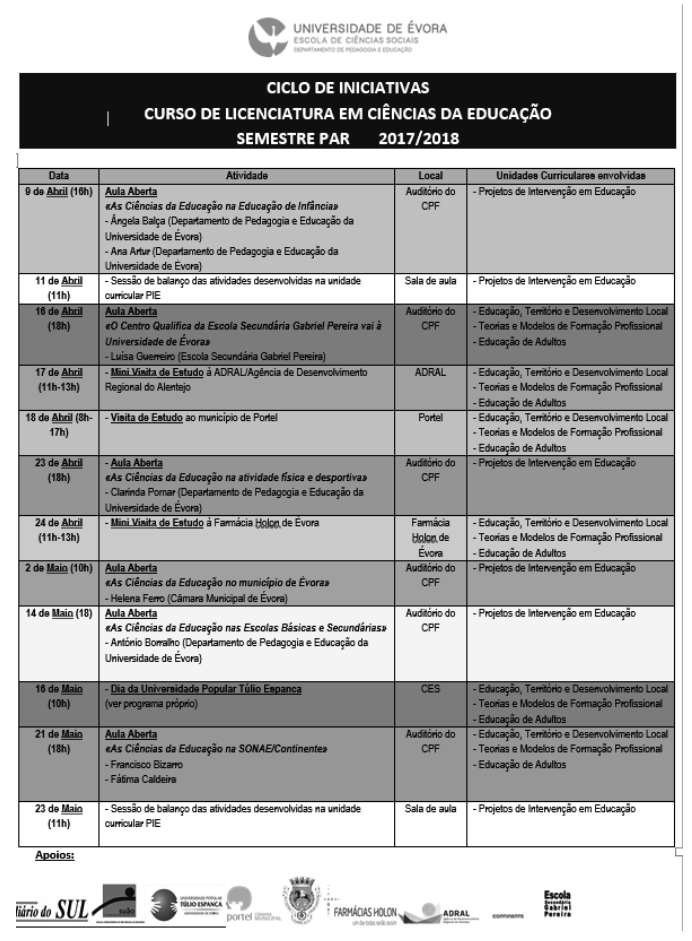

Figura 7. Cartaz do Ciclo de Iniciativas do Curso da Licenciatura em Ciências da Educação

O 9. ${ }^{\circ}$ aniversário da Universidade Popular Túlio Espanca da Universidade de Évora foi comemorado na Universidade de Évora. Com uma rede constituída por 7 polos, reuniram-se, no Auditório, aproximadamente três centenas de alunos de vários locais do Alentejo: São Miguel de Machede, Canaviais (Évora), Portel, Viana do Alentejo, Alandroal, Barrancos e Reguengos de Monsaraz. Os responsáveis institucionais e técnicos das entidades parceiras (autarquias), bem como um dos nossos primeiros parceiros - o Diário do Sul, através do seu Editor Executivo Paulo Piçarra - marcaram presença. 
De manhã, foram dinamizadas duas sessões/palestras asseguradas por docentes da academia eborense: (i) Prof. Doutor Rui Dias da Escola de Ciências e Tecnologias (aula sobre "Sustentabilidade Insustentável"; (ii) Prof. a Doutora Clarinda Pomar da Escola de Ciências Sociais (aula sobre Atividade Física, Saúde e Bem-Estar).

Seguiu-se o almoço no Colégio Luís António Verney.

De regresso ao Auditório, a tarde foi dedicada à atividade cultural, uma componente que traduz uma pequena mostra do que se faz, aprende e constrói, de forma, participada, gratuita e entre diferentes gerações, nos sete polos da UPTE/UÉ.

Em todas as atividades deste dia é de realçar o envolvimento dos estudantes da Universidade de Évora nesta iniciativa.

Em 2019, as comemorações terão de ser, ainda, mais expressivas. Nesse ano, a história de vida da UPTE/UÉ corresponderá a uma década de vida.

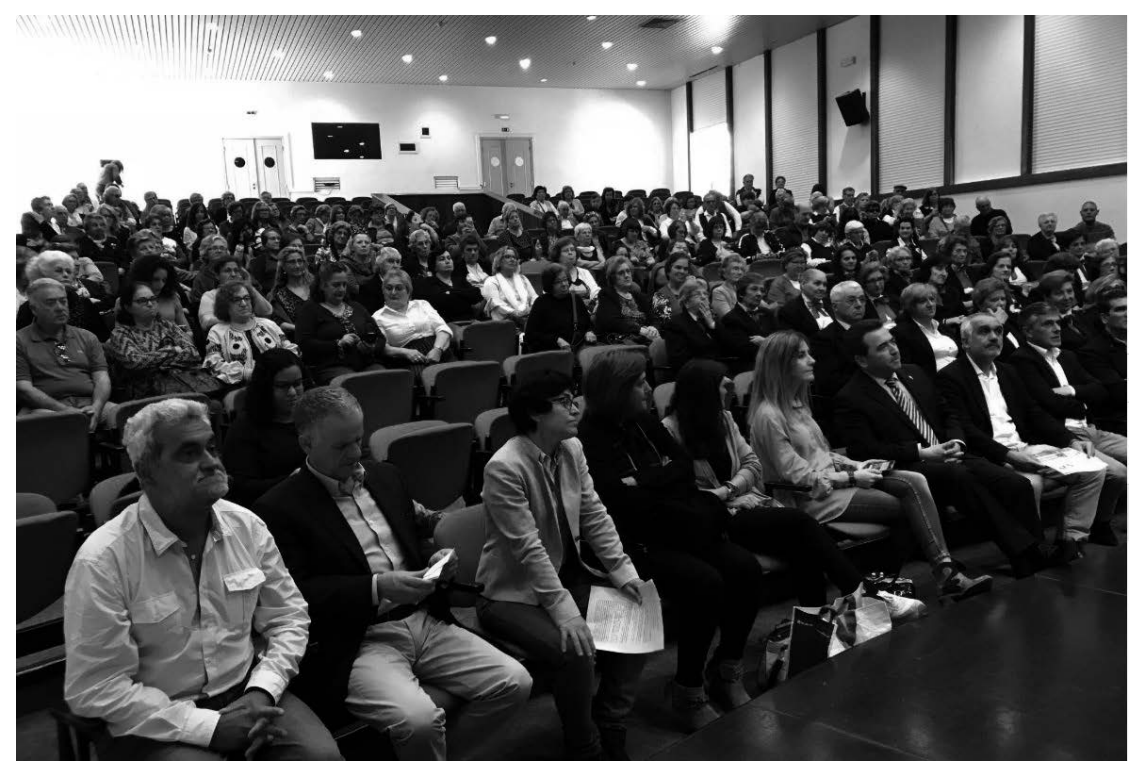

Figura 8. Dia da Universidade Popular Túlio Espanca/Comemoração do 9. ${ }^{\circ}$ aniversário 


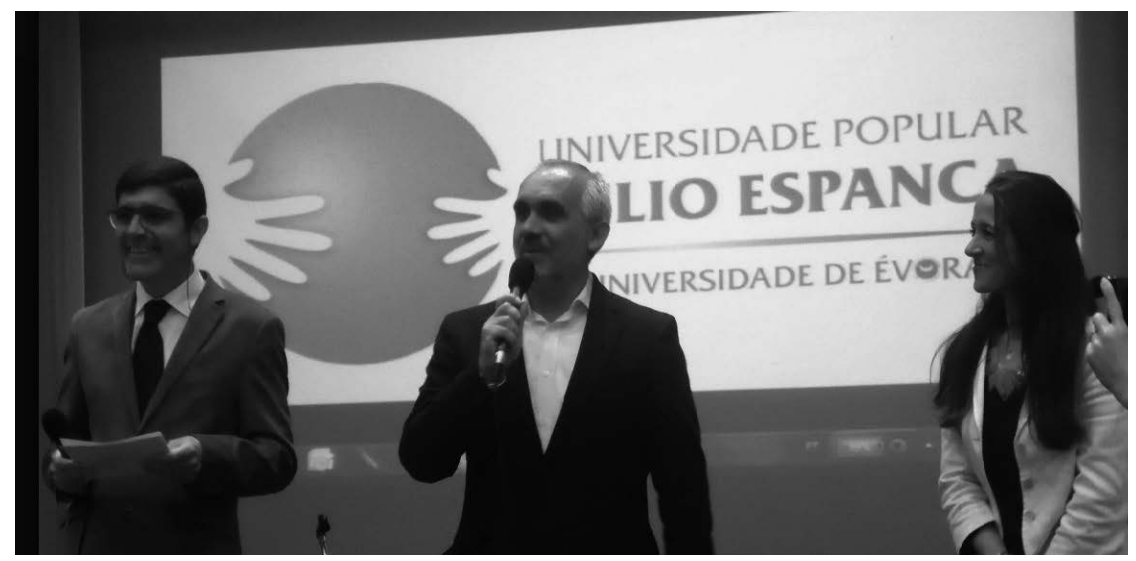

Figura 9. Dia da Universidade Popular Túlio Espanca/ Responsável institucional do Polo de Viana do Alentejo

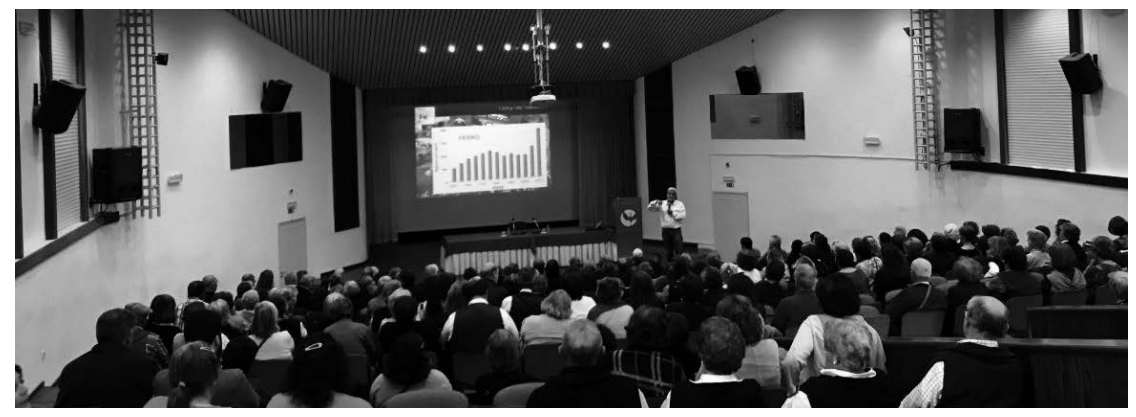

Figura 10. Dia da Universidade Popular Túlio Espanca/ Aula sobre "Sustentabilidade Insustentável"

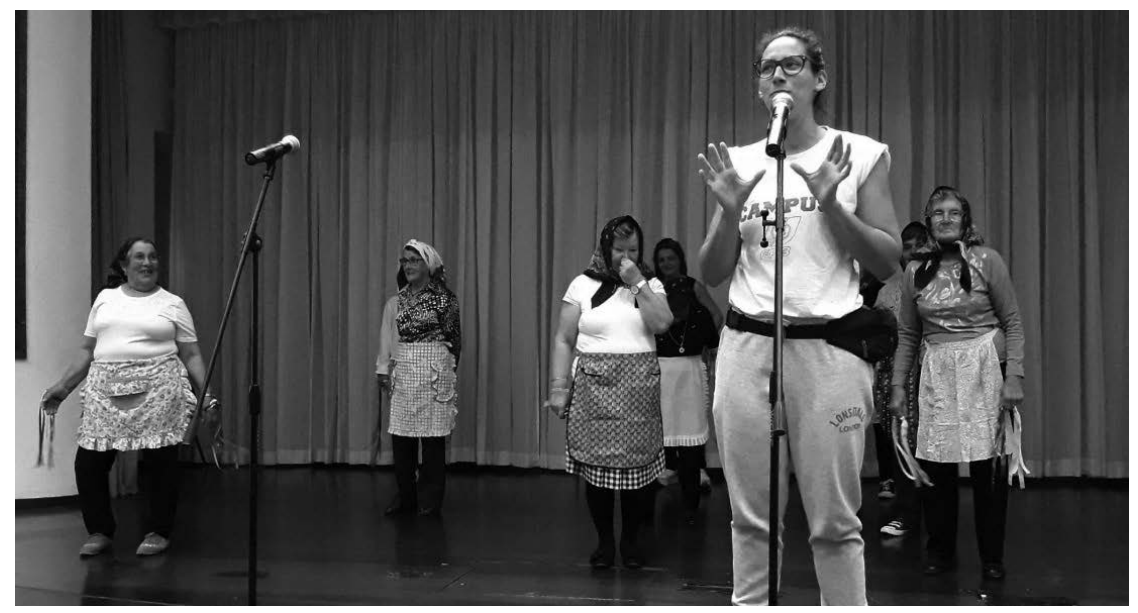

Figura 11. Dia da Universidade Popular Túlio Espanca/Momento Cultural com o Polo de São Miguel de Machede 


\section{DINAMIZADO PELOS POLOS DA UPTE/UÉ}

\subsection{Comemoração do $1 .^{\circ}$ ano de atividade do Polo de Canaviais/ Évora}

Em 12 de Março de 2017 comemorou-se um ano de atividade do Polo de Canaviais daUPTE/UÉ. Os responsáveis do Polo conseguiram construir, neste período, na freguesia de Canaviais, uma autêntica escola de educação popular que, hoje, presta um serviço público naquele território e no concelho de Évora. Isso deve-se ao esforço, trabalho e empenho do Presidente da Junta de Freguesia de Canaviais (Jerónimo José), da Presidente da Direção da Casa do Povo de Canaviais (Ana Pedrosa) e da Técnica Superior Margarida Oliveira, bem como de todos os professores, voluntários e amigos.
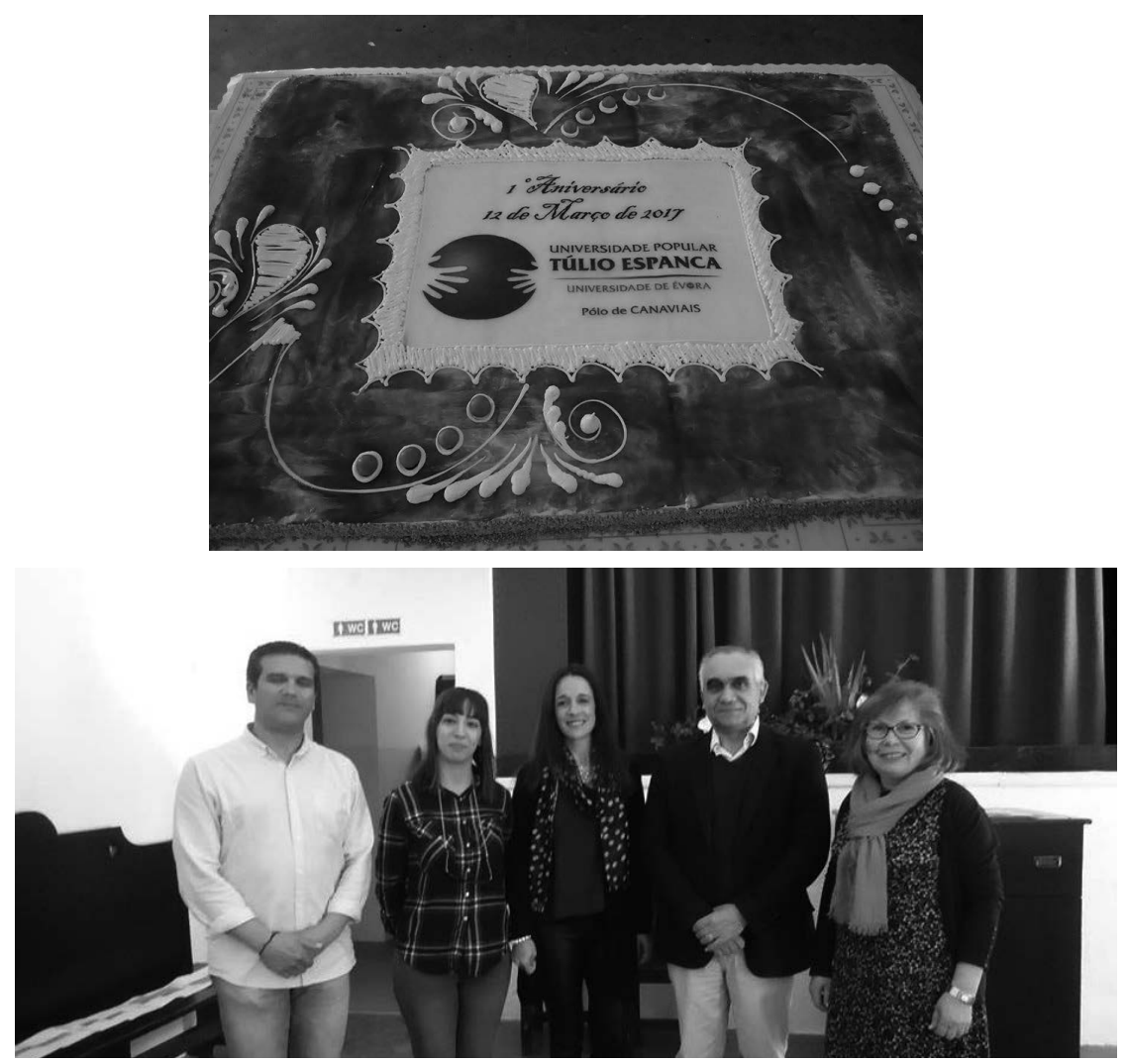

Figura 12. Comemoração do $1 .^{\circ}$ aniversário do Polo de Canaviais/Évora da UPTE/UÉ 


\section{DINAMIZADO PELOS POLOS DA UPTE/UÉ}

\subsection{Comemoração do $2 .^{\circ}$ ano de atividade do Polo de Canaviais/ Évora}

O Polo de Canaviais da UPTE/UÉ comemorou dois anos, em 18 de Março de 2018. A sessão contou, num primeiro momento, com uma sessão de abertura, onde estiveram presentes os responsáveis institucionais do Polo, o Diretor da UPTE/UÉ e um representante do Polo de São Miguel de Machede. Em seguida, decorreu a primeira atuação da Tuna do Polo e uma festa convívio entre todos os participantes.
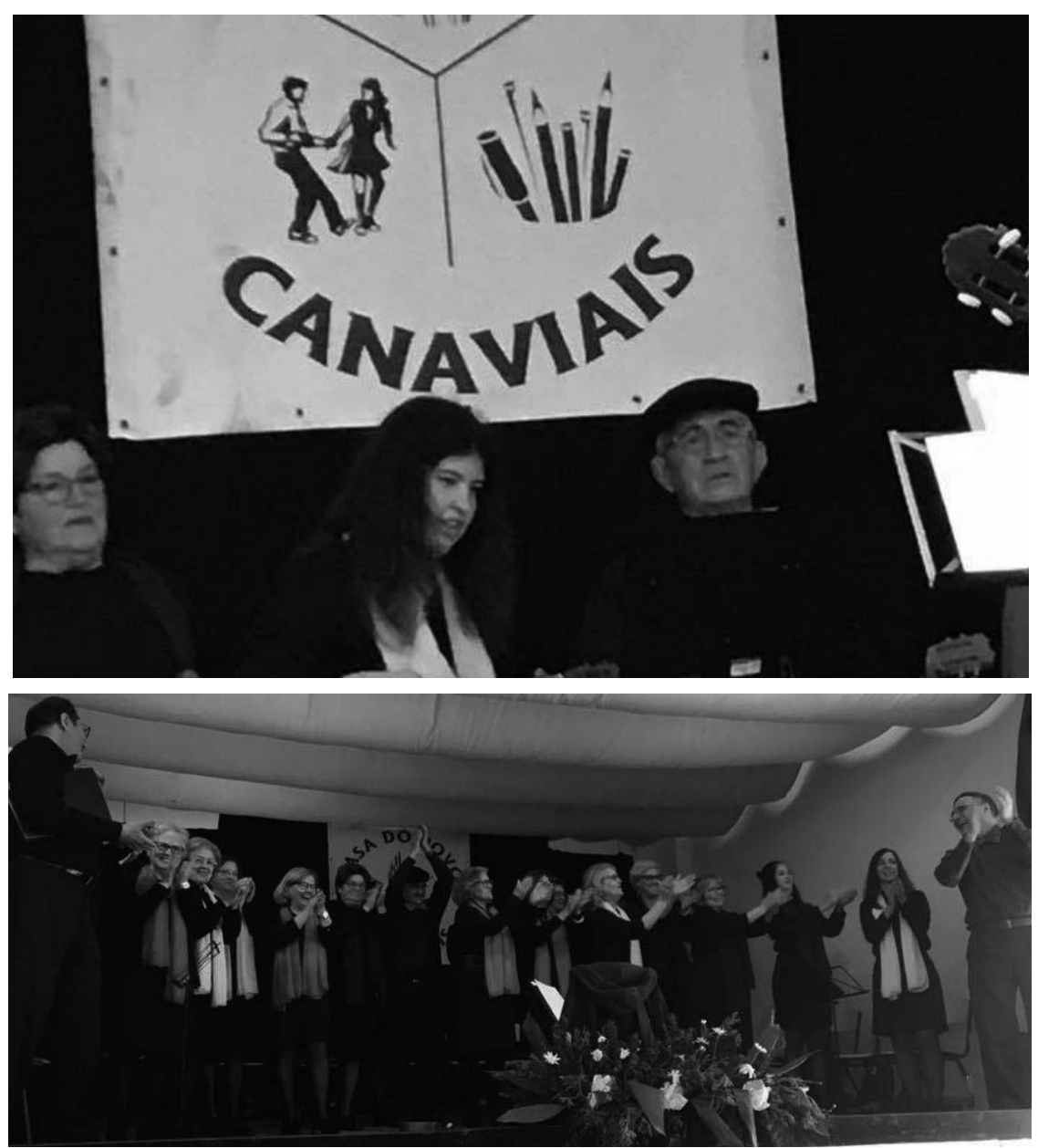

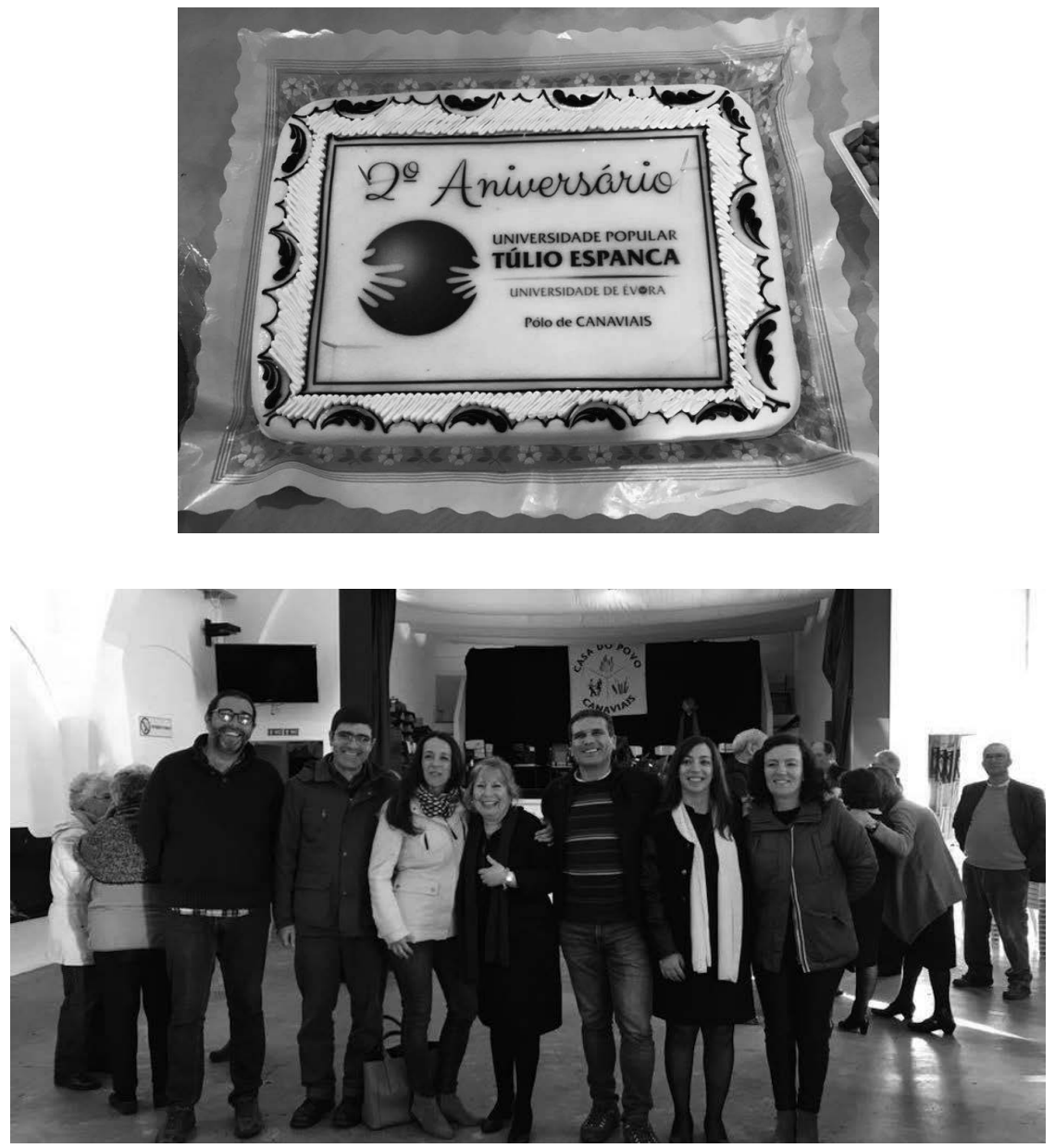

Figura 13. Alguns momentos da celebração do $2 .^{\circ}$ aniversário do Polo de Canaviais da UPTE/UÉ
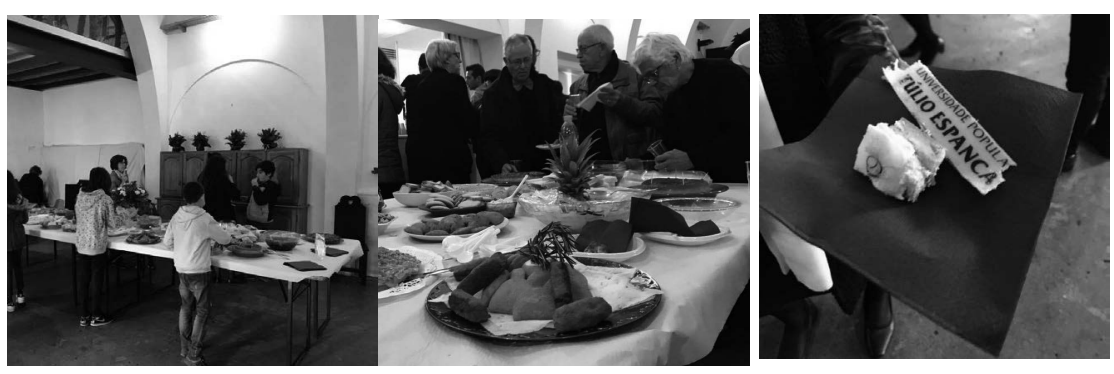

Figura 14. Festa de convívio na comemoração do $2 .^{\circ}$ aniversário do Polo de Canaviais da UPTE/UÉ 


\section{OUTRAS ATIVIDADES}

\subsection{Participação da UPTE/UÉ no Dia da Universidade de Évora/2017}

Pela primeira vez, na história da UPTE/UÉ, esta esteve presente nas celebrações do Dia da Universidade de Évora (1 de Novembro de 2016), com a GrandeTuna, constituída por elementos de todos Polos da Universidade Popular Túlio Espanca. Um momento simbólico e bonito, no qual se misturou a festa e o convívio, com os outros agrupamentos académicos da nossa academia.

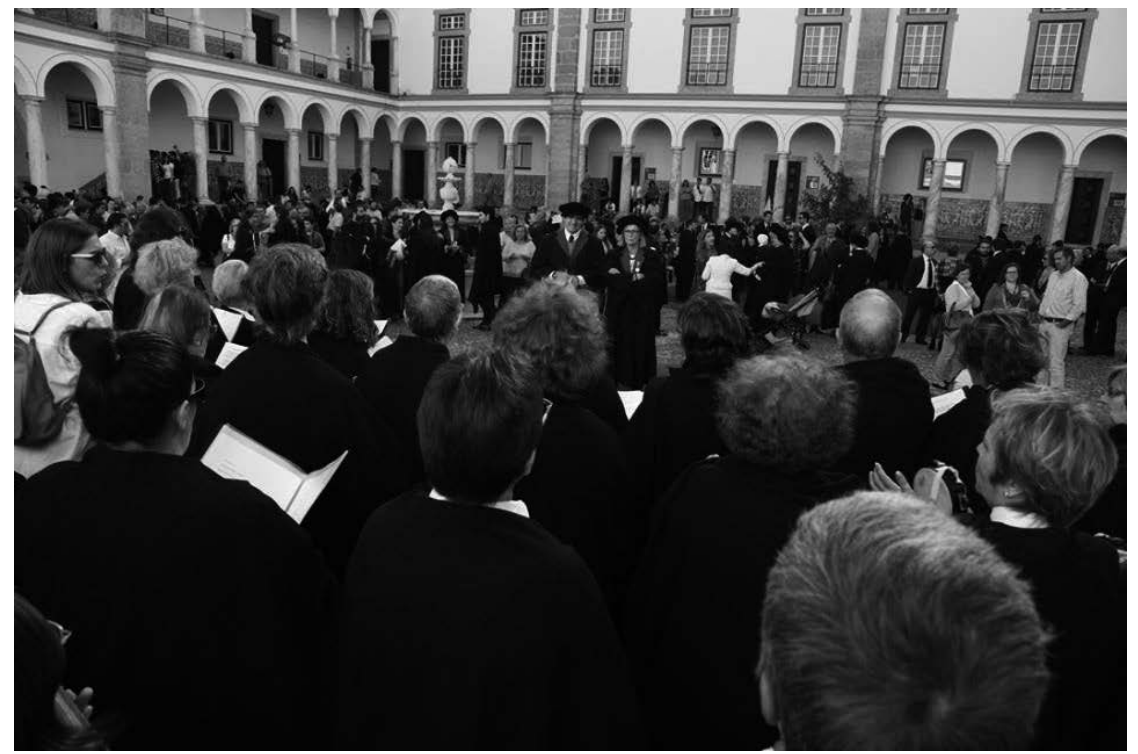

Figura 15. A TUNAlentejo (a Tuna da Universidade Popular Túlio Espanca da Universidade de Évora/UPTE/UÉ, com elementos de todos os polos) a atuar no Dia da Universidade de Évora, perante a Magnífica Reitora da UÉ, Professora Doutora Ana Costa Freitas, e o Diretor da UPTE/UÉ, Professor Doutor Bravo Nico. 


\section{AÇÕES DE DIVULGAÇÃO CIENTÍFICA} ORGANIZADO PELA UPTE/UÉ (COM A COLABORAÇÃO DE ESTUDANTES)

\subsection{Encontro de Educação Popular na Universidade de Évora}

Em 15 de Novembro de 2016, realizou-se o I Encontro de Educação Popular, uma iniciativa da Universidade Popular Túlio Espanca/Universidade de Évora.

Neste I Encontro de Educação Popular, procurou-se mostrar o que tem sido a caminhada científica, académica e cívica de construção da Educação, com mais de mil concidadãos envolvidos em cinco territórios: Alandroal, Canaviais, Portel, São Miguel de Machede e Viana do Alentejo.

De assinalar a participação dos estudantes, em particular, do Curso da Licenciatura em Ciências da Educação, na organização das atividades, apoio e acompanhamento dos alunos dos vários polos.

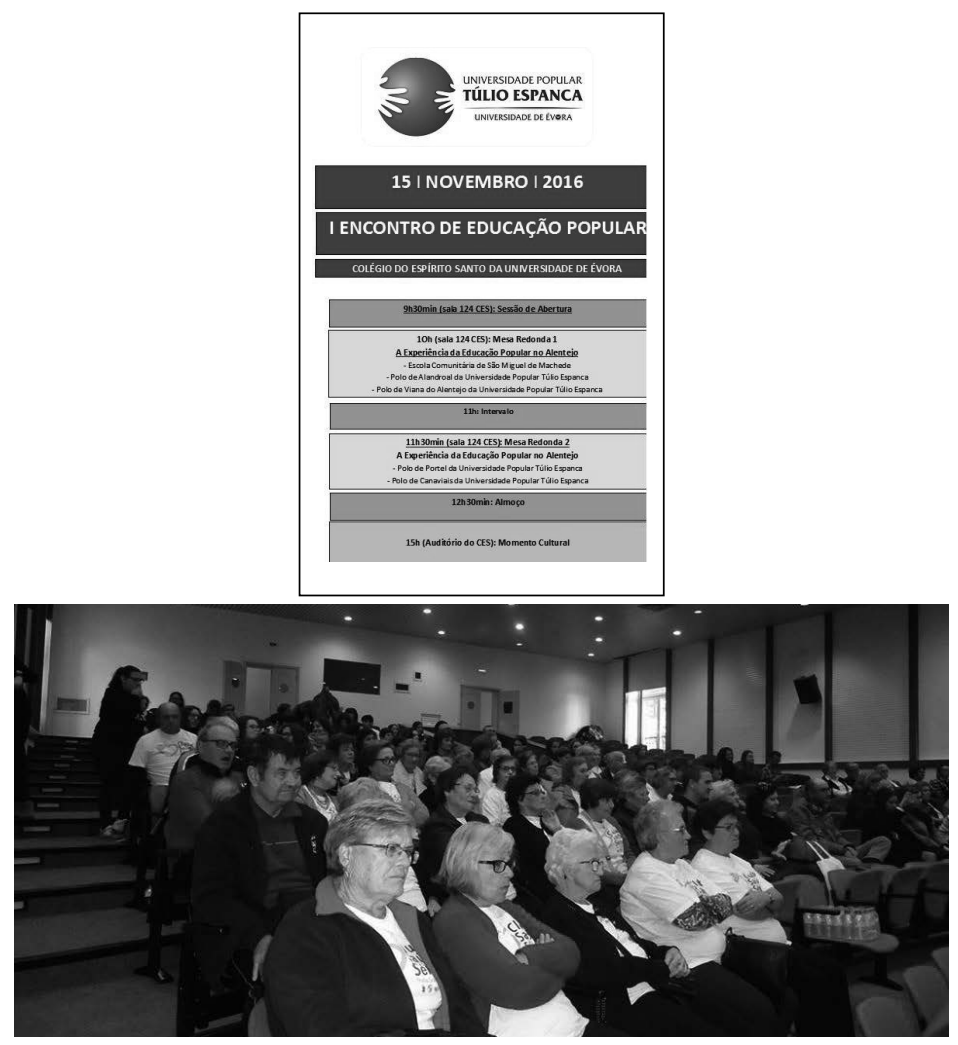

Figura 16. I Encontro de Educação Popular

Organizado pela UPTE/UÉ (com a colaboração de estudantes) 


\subsection{Aprender no Alentejo - Encontro Regional de Educação}

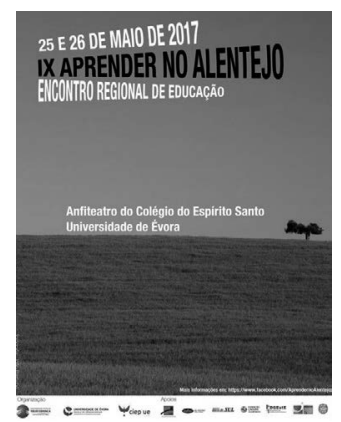

Figura 17. Cartaz do IX Aprender no Alentejo - Encontro Regional de Educação

O Aprender no Alentejo é um Encontro Regional de Educação que se realiza na Universidade de Évora, desde 2003. Já foram realizados 8 encontros regionais e editados 7 livros, nos quais estão publicados, aproximadamente, duas centenas e meia de comunicações, protagonizadas por várias instituições do Alentejo (escolas, autarquias, empresas, associações, grupos informais, entre outras), investigadores, professores, alunos e outros especialistas em educação.

Em 2017, o Aprender no Alentejo foi organizado pelo Departamento de Pedagogia e Educação da Universidade de Évora, Universidade Popular Túlio Espanca e o Centro de Investigação em Educação e Psicologia da Universidade de Évora.

A UPTE/UÉ integrou a Mesa 4, em 26 de Maio de 2017, na qual se debateu o tema da Educação e Formação de Adultos "Novas Escolas e Novos Paradigmas de Educação e Formação ao Longo da Vida", juntamente com outras duas instituições: a Universidade Sénior de Évora e a Centro Qualifica do Agrupamento de Escolas de Vendas Novas. A UPTE/UÉ fez-se representar, nessa mesa, pela Professora Doutora Lurdes Pratas Nico.

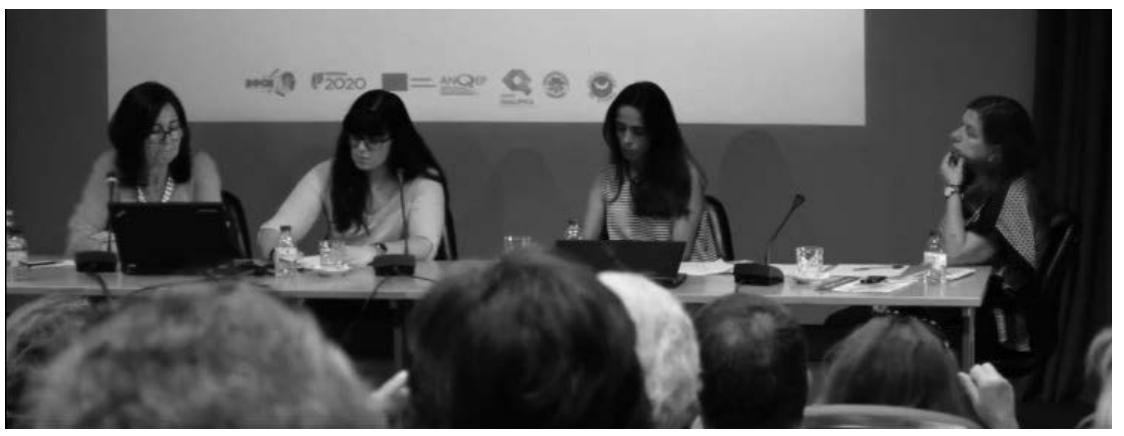

Figura 18. Presença da UPTE/UÉ na Mesa 4 do Encontro 
Além desta participação, ocorreu, ainda, a participação dos vários Polos da UPTE/UÉ, através da apresentação de comunicações livres acerca do trabalho que tem vindo a desenvolver em cada um dos seus territórios:

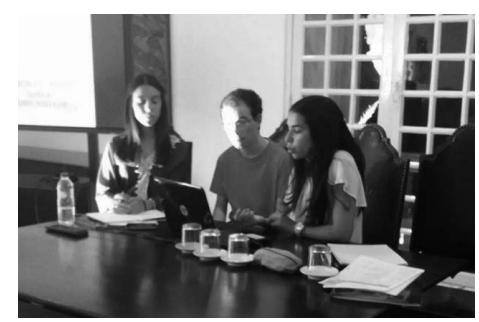

Figura 19. Polo de São Miguel de Machede da UPTE/UÉ na Sala de Comunicações Livres

De relevar a importante participação de vários estudantes da Universidade de Évora, que participaram na organização e através de comunicações livres acerca do trabalho que tem vindo a desenvolver no âmbito dos seus percursos formativos (formação inicial e pós-graduada).

Apresentam-se, em seguida, os títulos de algumas das comunicações livres, apresentadas por estudantes da Universidade de Évora (formação inicial):

QUADRO 2. COMUNICAÇÕES LIVRES APRESENTADAS PELOS ESTUDANTES APRESENTADAS NO APRENDER NO ALENTEJO*

\begin{tabular}{|c|c|}
\hline Autor(es) (estudantes) & Título da comunicação \\
\hline $\begin{array}{l}\text { Ana Coelho, André Rebelo, Mafalda } \\
\text { Alegria \& Rita Clérigo }\end{array}$ & $\begin{array}{l}\text { Possíveis percursos educativos para } \\
\text { prolongar a formação de um jovem adulto }\end{array}$ \\
\hline Juliana Basi \& Maira Trentin & $\begin{array}{l}\text { Ser ERASMUS no Alentejo e experiências } \\
\text { extracurriculares no âmbito artístico }\end{array}$ \\
\hline $\begin{array}{l}\text { Júlia Santos Silva, Nayara Sant’Anna } \\
\text { de Souza, Rúben Neves \& Sofia Dias }\end{array}$ & $\begin{array}{l}\text { Como construir um processo educativo } \\
\text { para um adulto a partir de um território? }\end{array}$ \\
\hline José Grilo & $\begin{array}{l}\text { Oriola/Portel: um território de } \\
\text { aprendizagem }\end{array}$ \\
\hline Maira Trentin & $\begin{array}{l}\text { Impactos da atuação do profissional de } \\
\text { Ciências da Educação na elaboração de um } \\
\text { plano de aprendizagem para adultos }\end{array}$ \\
\hline Nadine Charrua \& Sara Gomes & $\begin{array}{l}\text { Um projeto de aprendizagem para adultos } \\
\text { na área das TIC }\end{array}$ \\
\hline $\begin{array}{l}\text { Ana Carriço, Ana Pimentel \& Sara } \\
\text { Cardeira }\end{array}$ & Uma viagem pelas redes sociais \\
\hline $\begin{array}{l}\text { Elena Laplace, Inês Silva, Rute } \\
\text { Guedelha \& Vânia Pires }\end{array}$ & Quero votar com consciência \\
\hline
\end{tabular}



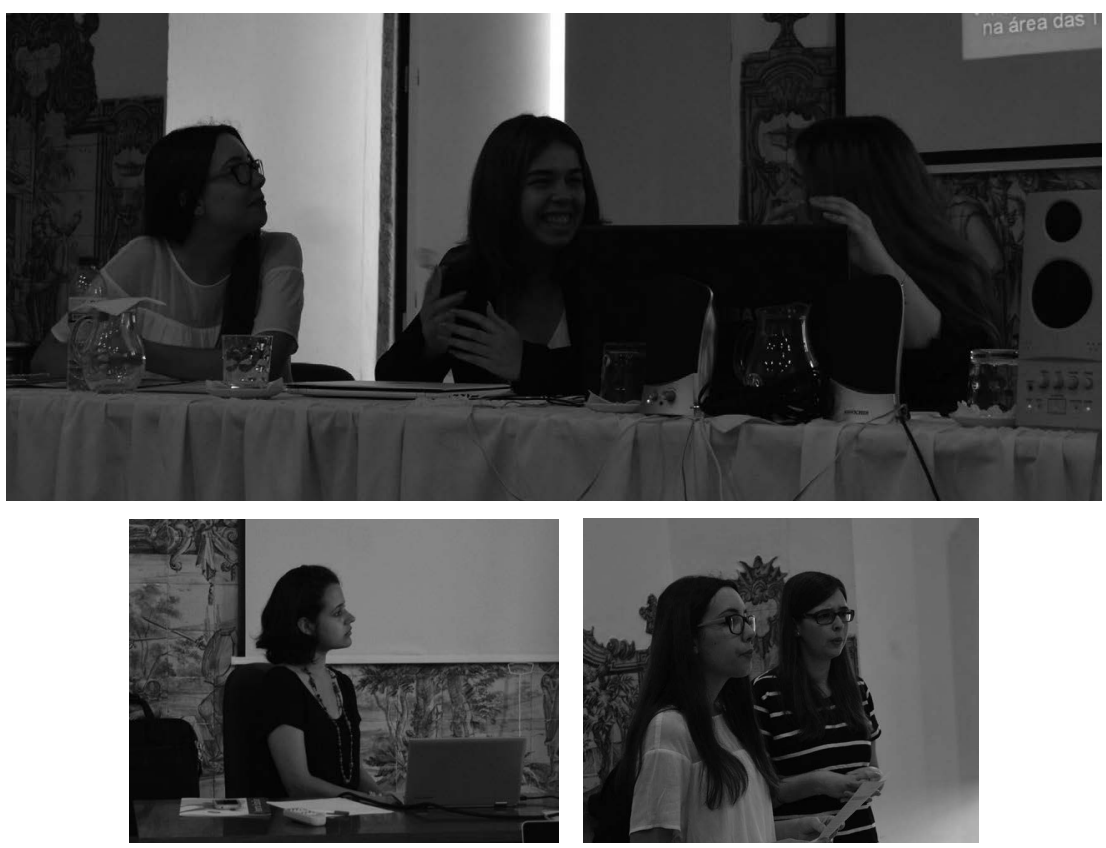

Figura 20. Estudantes da Licenciatura em Ciências da Educação nas Salas de Comunicações Livres

Os textos das comunicações livres apresentadas na IX edição Aprender no Alentejo Encontro Regional de Educação, encontram-se publicados no livro Aprenderes do Alentejo (Nico \& Nico, 2018).

\section{Vídeos do Encontro}

Divulgação/promoção do Encontro: https://www.facebook.com/ AprendernoAlentejo/videos/1593549370664238/

Momento cultural: https://www.facebook.com/ceevora/ videos/1214012952058279/

Síntese do encontro: https://www.facebook.com/AprendernoAlentejo/ videos/1603363719682803/

\section{Notícias na Comunicação Social:}

https://www.facebook.com/AprendernoAlentejo/ photos/a.493351737350679/1612425065443335/?type=3\&theater 


\section{PARTICIPAÇÃO DA EQUIPA DA UPTE/UÉ EM EVENTOS CIENTÍ- FICOS NACIONAIS}

A equipa de investigação participou em reuniões e ações de divulgação científica do projeto, em eventos nacionais e internacionais, conforme se descreve, em seguida.

\subsection{Fórum sobre o tema "Alfabetizar no século XXI - o novo para- digma de alfabetização solidária"}

A convite da APEFA - Associação Portuguesa de Educação e Formação de Adultos, o Diretor da UPTE/UÉ, Professor Doutor Bravo Nico, participou, em 8 de Setembro de 2017, no Cine-Teatro em Aljustrel, num Fórum sobre o tema "ALFABETIZAR NO SEC XXI - o novo paradigma de alfabetização solidária”. Este evento quis, assim, assinalar o Dia Internacional da Alfabetização.

\section{PROGRAMA}

$10 h 00$ - Receção dos participantes $10 h 30$ - SESSÃO DE ABERTURA

- Momento Musical, Sociedade Musical de Instrução e Recreio Aljustrelense

- Miguel Cabrita, Secretário de Estado do Emprego (abertura ou encerramento*)

- Nelson Brito, Presidente da Câmara Municipal de Aljustrel

- Armando Loureiro, Presidente da APEFA

\section{1 h00 - ALFABETIZAR NO SEC XXI - O NOVO PARADIGMA DE ALFABETIZAÇÃO SOLIDÁRIA}

- "Percursos de cidadania, alfabetização solidária"

Antónia Gonçalves, APEFA e Armando Loureiro, APEFA

- "Projeto ANIMA SÉNIOR+

Conceição Parreira, Câmara Municipal de Aljustrel

- "Aprender dos outros, com os outros, na comunidade"

Lurdes Nico e Bravo Nico, Universidade Popular Túlio Espanca | Universidade de Évora | Conselho Consultivo APEFA

- "Alfabetizar, emergência e contextos “

Alberto Melo, APCEP | Universidade do Algarve

- "O Erasmus + e a Educação de Adultos em Portugal”

Eugénia Inácio, Agência Nacional ERASMUS

ESPAÇO DE DEBATE E REFLEXÃO

Moderador: António Espírito Santo, Especialista em EFA 


\section{$12 h 45$ - SESSÃO DE ENCERRAMENTO}

Miguel Belinho, APEFA

João Couvaneiro, ANQEP

Conceição Parreira, Vereadora da Educação da Câmara Municipal de Aljustrel

Momento Musical, Sociedade Musical de Instrução e Recreio Aljustrelense

\section{PARTICIPAÇÃO DA EQUIPA DA UPTE/UÉ EM EVENTOS CIENTÍ- FICOS NACIONAIS}

\subsection{Seminário Nacional de Educação e Formação de Adultos}

A convite da APEFA - Associação Portuguesa de Educação e Formação de Adultos, o Diretor da UPTE/UÉ ( também Membro do Conselho Consultivo da APEFA), participou no IV Seminário Nacional de Educação e Formação de Adultos, dia 6 de Julho de 2018, em Almada. O tema da sua intervenção incidiu nas Universidades Populares e no exemplo concreto da UPTE/UÉ, como projeto de atuação integrada e global de Educação num território.

\section{PARTICIPAÇÃO DA EQUIPA DA UPTE/UÉ EM EVENTOS CIENTÍ- FICOS INTERNACIONAIS}

2.5. XIV Congresso Internacional Galego-Português de Psicopedagogia

A Professora Doutora Lurdes Pratas Nico, em representação da UPTE/ UÉ, participou no XIV Congresso Internacional Galego-Português de Psicopedagogia (Universidade do Minho, Braga, entre 6 e 8 de Setembro de 2017), divulgando, dessa forma, as atividades do projeto "Currículo, Educação Popular e Responsabilidade Social na Universidade de Évora”. 


\section{AÇÕES DE DIVULGAÇÃO NA COMUNICAÇÃO SOCIAL NOS MEIOS DE COMUNICAÇÃO SOCIAL NACIONAIS}

\subsection{Jornal Público}

Na edição de 3 de Fevereiro de 2017, o Jornal Público publicou uma notícia acerca das Universidades Populares, na qual se inscreve a Universidade Popular Túlio Espanca da Universidade de Évora. Esta notícia evidenciou o reconhecimento social do potencial educativo do projeto da Universidade Popular Túlio Espanca (disponível em: https://www.publico. pt/2017/02/03/sociedade/noticia/as-universidades-chamaram-os-seniores-e-eles-estao-a-entrar-nas-salas-de-aula-1760660).

Nos meios de comunicação social regionais, Página Web e Redes Sociais da UPTE/UÉ e respetivos Polos

\subsection{Rádios e Jornais}

O alargamento da rede de Polos da UPTE/UÉ, através abertura dos Polos de Barrancos e de Reguengos de Monsraz, teve divulgação nos órgãos de comunicação regionais.

- Rádio Pax: http://www.radiopax.com/index.php?go=noticias\&id=13485, 5 de Julho de 2017

- Diário do Alentejo: http://www.pt.cision.com/cp2013/ClippingDetails. aspx?id=16c0ced3-bc5b-4eb9-aace-ef2f7991c1f2\&analises=1, 7 de Julho de 2017

- Jornal Diário do Sul: notícia publicada dia 5 de Julho, página 15

- https://www.diariodosul.com.pt/noticias/ultimas-noticias/1989-reguengos-de-monsaraz-vai-ter-polo-da-universidade-popular-tulio-espanca.html

- http://www.radiocampanario.com/ultimas/regional/reguengos-de-monsaraz-tera-polo-da-universidade-popular-tulio-espanca-fazendo-uma-diferenciacao-positiva-na-vida-da-populacao-diz-autarca-do-municipio-c-som 


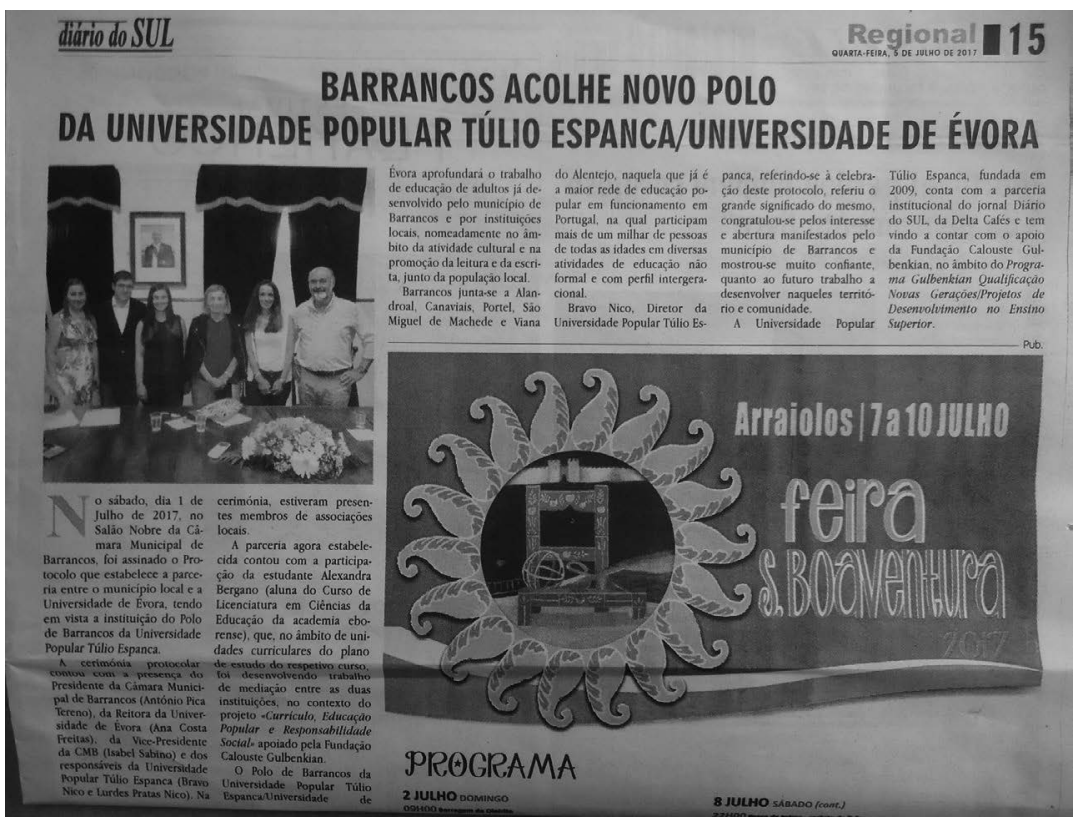

Figura 21. Notícia sobre a abertura do Polo da UPTE/UÉ em Barrancos

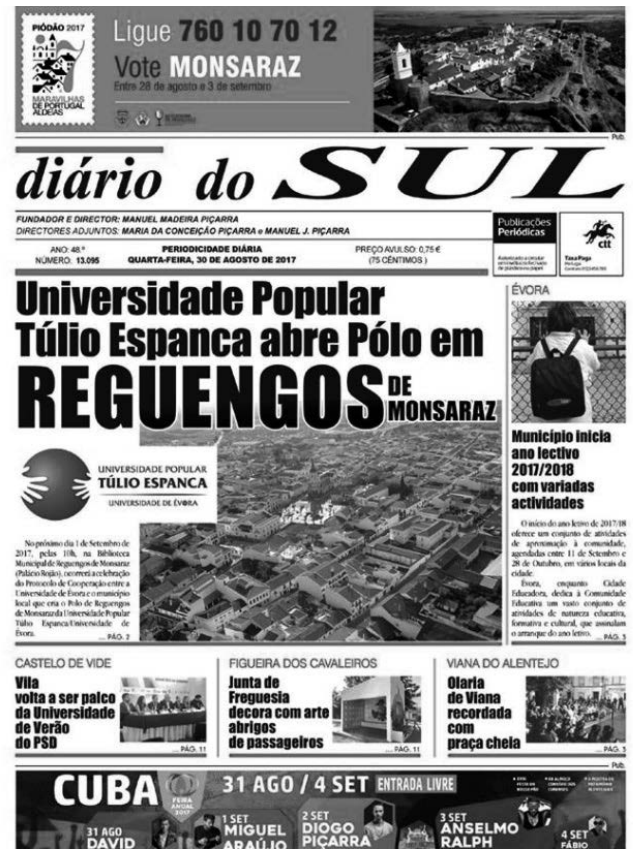

Figura 22. Capa do Jornal Diário do Sul. Destaque para a abertura do Polo de Reguengos de Monsaraz da UPTE/UÉ 
Apresentam-se, em seguida, outros exemplos de divulgação da atividade da Universidade Popular Túlio Espanca/Universidade de Évora na comunicação social.

diário do SUL Regional 5

Clube de Teatro, A nossa História, Meditaçũo, Bordados e Costuras, Tuna e Informática

Polo de Reguengos de Monsaraz da Universidade Popular Túlio Espanca inicia ano letivo
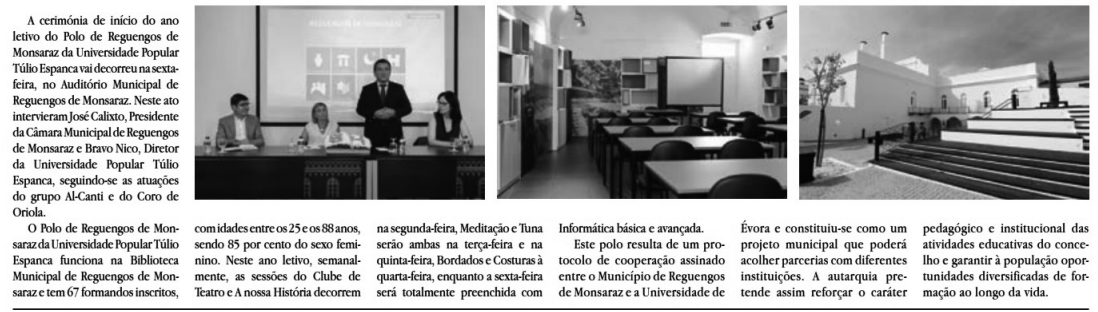

Figura 23. Notícia no Jornal Diário do Sul. Destaque para o início das atividades no Polo de Reguengos de Monsaraz

8. Aniversário do Pólo de Viana do Alentejo da UPTE/UÉ

\section{Universidade tem vindo a contribuir para 0 envelhecimento ativo no concelho}

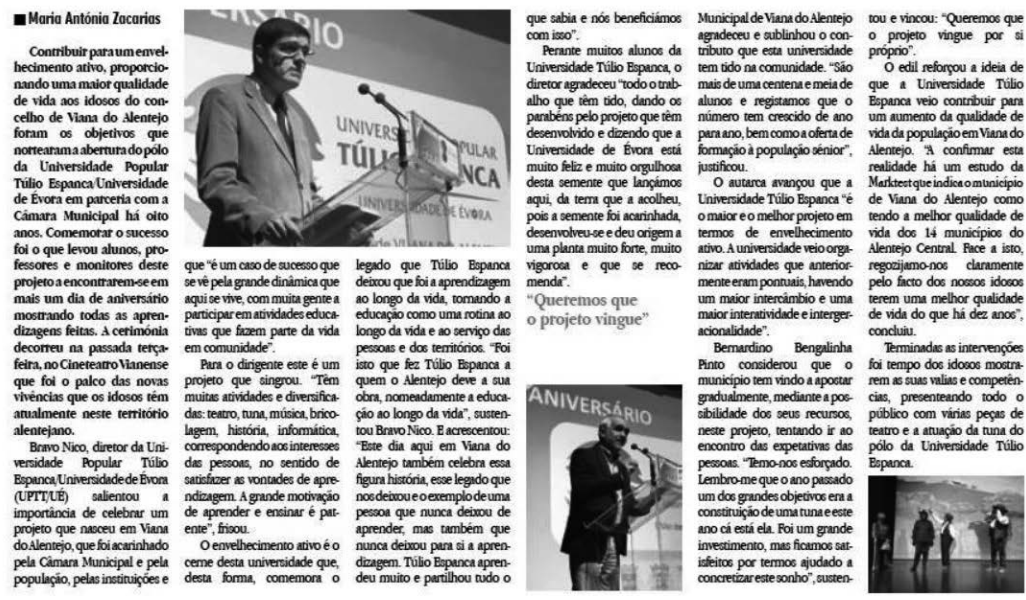

Figura 24. Notícia no Jornal Diário do Sul. Destaque para o $8 .^{\circ}$ aniversario do Polo de Viana do Alentejo da UPTE/UÉ (11 de Maio de 2018) 

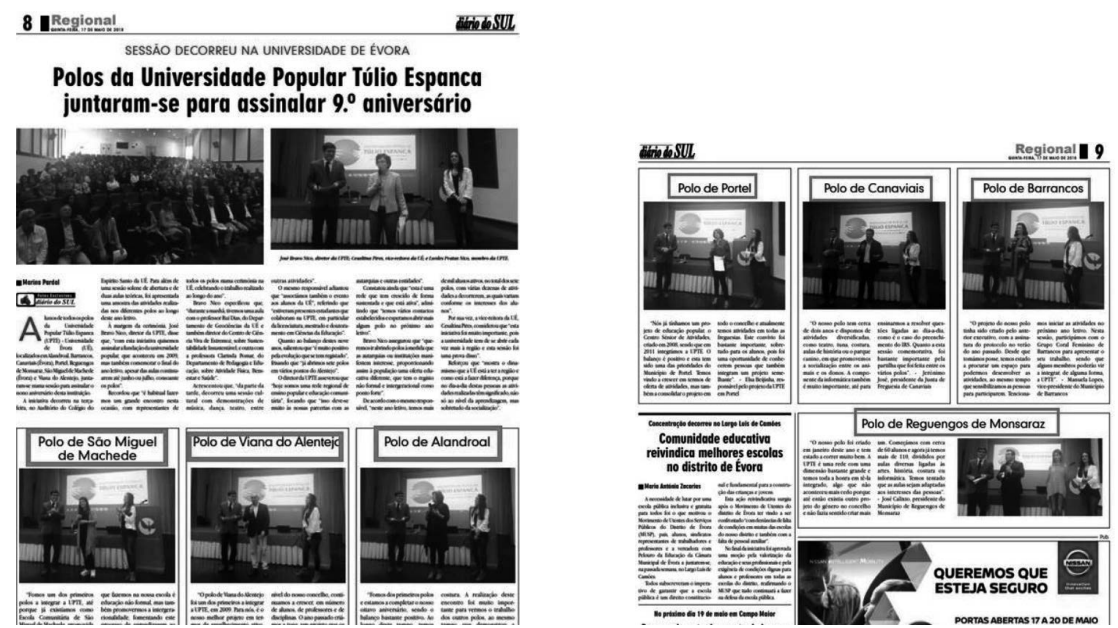

Figura 25. Notícia no Jornal Diário do Sul. Destaque para o 9. ${ }^{\circ}$ aniversário da UPTE/UÉ (17 de Maio de 2018)

As atividades desenvolvidas no âmbito do projeto foram, amplamente, divulgadas na página Web e na rede social da Universidade Popular Túlio Espanca ( www.utulioespanca.uevora.pt;https://www.facebook.com/ Universidade-Popular-Túlio-Espanca-Universidade-de-Évora),bem e dos Polos.

- http://www.cm-reguengos-monsaraz.pt/pt/site-municipio/educacao/ rede-escolar/Paginas/universidade-popular-tulio-espanca-polo-reguengos-de-monsaraz.aspx

- http://www.utulioespanca.uevora.pt/Actividades/

Polo-de-Reguengos-de-Monsaraz

\section{PUBLICAÇÃo}

Livro resultante do projeto desenvolvido pela UPTE/UÉ e financiado pela Fundação Calouste Gulbenkian "Janelas Curriculares de Educação Popular no Ensino Superior Universitário”

4.1. Apresentação pública do Livro «Janelas Curriculares de Educação Popular na Universidade de Évora: para um conhecimento académico mais humanista e solidário»

Este livro foi apresentado em 29 de Novembro de 2016, pelas 18h, na Sala de Docentes do Colégio do Espírito Santo da Universidade de Évora. A obra, da autoria dos Professores Doutores Bravo Nico e Lurdes Pratas Nico, foi apresentada pela Magnífica Reitora da Universidade de Évora, Professora Doutora Ana Costa Freitas. 
O livro traduz a atividade da UPTE/UÉ, no âmbito da concretização do projeto anteirior "Janelas Curriculares de Educação Popular no Ensino Superior Universitário" (Nico \& Nico, 2016a). Nesta sessão esteve presente o Diretor do Serviço de Educação e Bolsas da Fundação Calouste Gulbenkian, Dr. Carmelo Rosa, a quem se agradeceu, pessoal e formalmente, o apoio prestado.
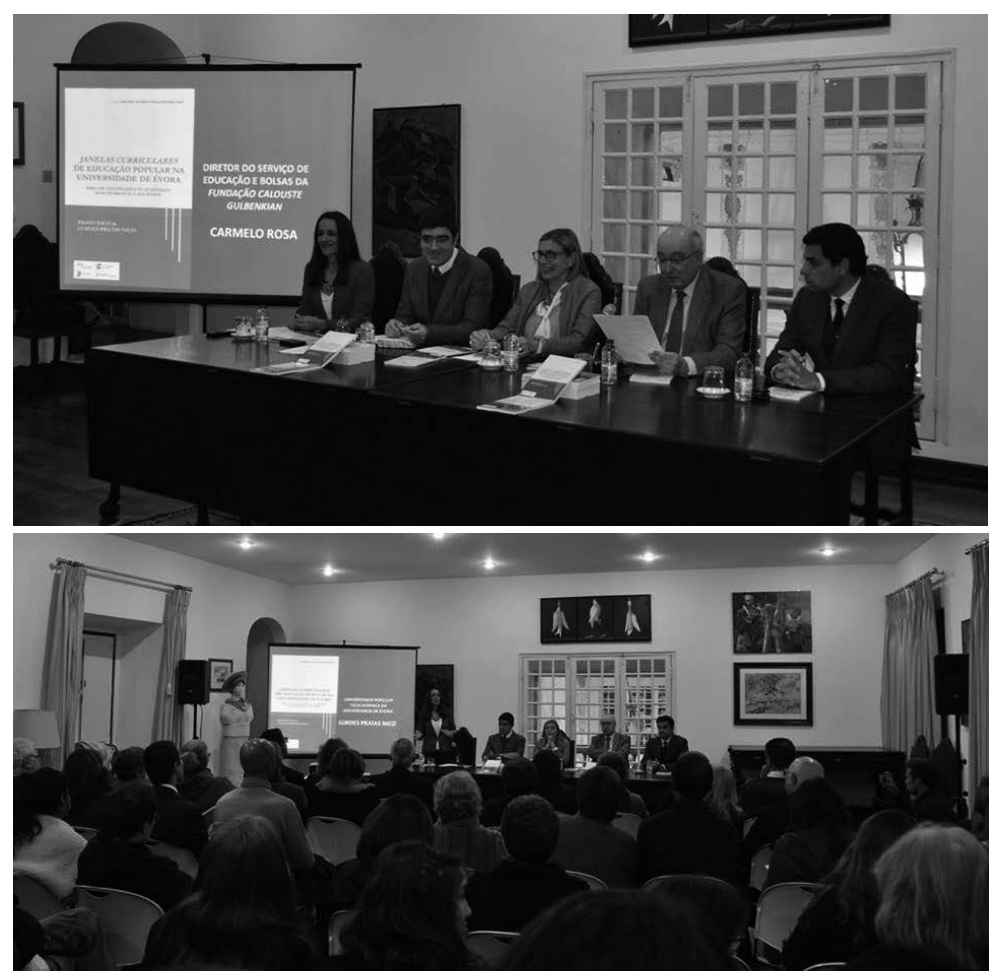

Figura 26. Apresentação Pública do livro «Janelas Curriculares de Educação Popular na Universidade de Évora: para um conhecimento académico mais humanista e solidário»

Livro - Atas do VIII Encontro Regional de Educação "Aprender no Alentejo"

\subsection{Apresentação pública do livro "Didáticas do Alentejo" (participação dos estudantes da Licenciatura em Ciências da Educação)}

O livro "Didáticas do Alentejo" resultou da da VIII edição do congresso "Aprender no Alentejo - Encontro Regional de Educação", sendo uma edição das Edições Pedago, da Universidade de Évora e da UPTE/UÉ (Nico \& Nico, 2016b).

Este livro foi apresentado, publicamente, em 23 de Fevereiro de 2017, na Sala de Docentes do Colégio Espírito Santo da Universidade de Évora. 
Estas publicações, que têm resultado dos congressos «Aprender no Alentejo», assumem-se como um autêntico repositório do universo de contextos de aprendizagem existentes na região alentejana, em todas as dimensões da educação: a dimensão formal e escolar, os contextos de aprendizagem não escolares, mas muito importantes na qualificação dos alentejanos (as escolas de música, a formação profissional presente nos ofícios e artes tradicionais, as associações de desenvolvimento local, as instituições sociais, os grupos desportivos e culturais, as autarquias locais, etc.). Através destas publicações (sete, no total), pretende-se conhecer, valorizar e divulgar as escolas fora da escola que existem no Alentejo.

Este livro retrata as pessoas, as didáticas de ensinar e de aprender, o tratamento fraterno e amigo. Tudo isto, e muito mais faz, o nosso Alentejo, como bem o souberam (d)escrever Antunes da Silva e Túlio Espanca.

Na organização da sessão, foram envolvidos os estudantes da Licenciatura em Ciências da Educação (2. ${ }^{\circ}$ ano).

O conteúdo do livro pode ser consultado através do link https://dspace. uevora.pt/rdpc/handle/10174/18918.
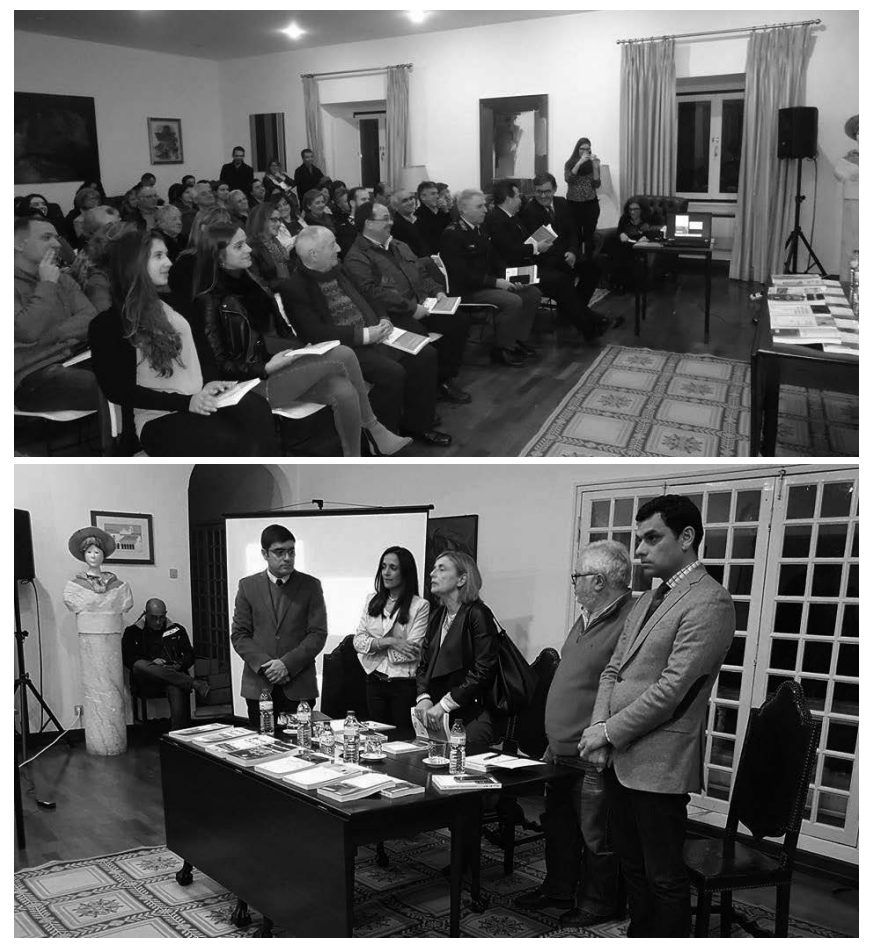

Figura 27. Apresentação Pública do livro «Didáticas do Alentejo” 
PUBLICAÇÃO DE ARTIGO EM REVISTA COM ARBITRAGEM CIENTÍFICA

\subsection{Publicação de artigo em Revista com Arbitragem Científica}

A equipa de investigação da UPTE/UÉ participou no XIV Congresso Internacional Galego-Português de Psicopedagogia. Dessa participação, resultou a publicação de um artigo em revista com arbitragem científica Revista de Estudios e Investigación em Psicología Y Educación (Nico \& Nico, 2017).

\section{5. "AULA TELEFONIA"}

A Universidade Popular Túlio Espanca, em parceria com o grupo de comunicação social Diário do SUL/Rádio Telefonia do Alentejo, deu início a um projeto de educação popular denominado «AULA TELEFONIA». A finalidade consiste em abordar um tema de interesse geral, em cada mês, com o recurso a especialistas na área e com difusão dessa informação, através do jornal, rádio e tv.

\section{AULA TELEFONIA 1}

\subsection{Tema: As Vacinas}

No mês de Janeiro de 2018, o tema escolhido foi «As Vacinas», tendo sido entrevistado o Dr. Augusto Santana Brito, médico de saúde pública.

O conteúdo escrito desta entrevista foi publicado no jornal Diário do Sul e emitido na Rádio Telefonia do Alentejo, domingo, 7 de Janeiro, tendo ficado disponível, em podcast, para escuta posterior.

O objetivo consiste em fazer chegar a informação a maior número de pessoas: à comunidade em geral e aos participantes dos polos, para que o conteúdo possa ser lido e trabalhado nas atividades de cada Polo.

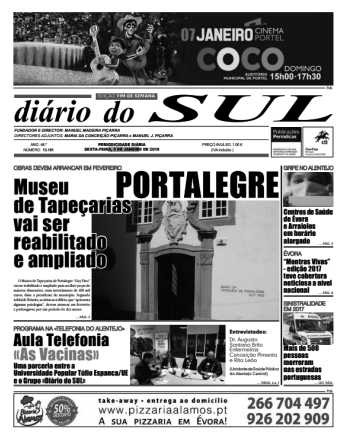

Figura 28. Capa do Jornal Diário do Sul. Destaque para "Aula Telefonia 1" sobre "As Vacinas" 


\section{AULA TELEFONIA 2}

\subsection{Tema: A Arte Chocalheira de Alcáçovas}

No mês de Fevereiro de 2018, o tema escolhido foi «A Arte Chocalheira», tendo sido entrevistados dois mestres chocalheiros de Alcáçovas (Guilherme Maia e Francisco Cardoso dos Chocalhos Pardalinho).

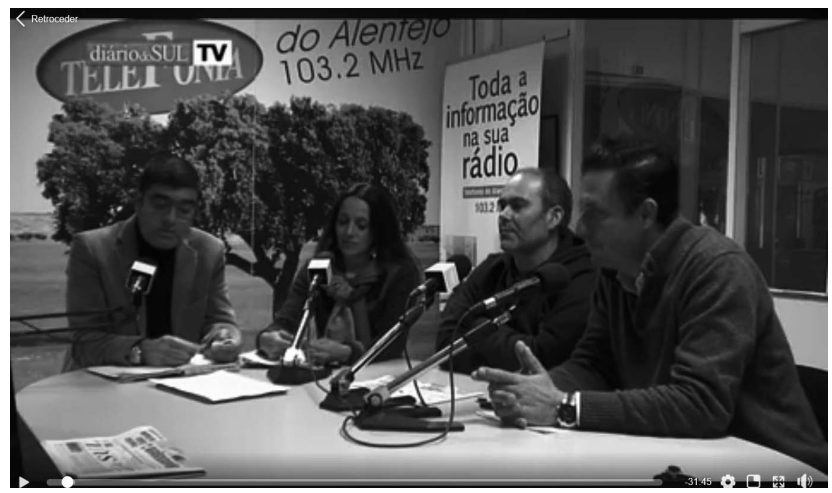

Figura 29. "Aula Telefonia 2" sobre a "Arte Chocalheira”

O conteúdo escrito desta entrevista foi publicado no jornal Diário do SUL e emitido na Rádio Telefonia do Alentejo, domingo, tendo ficado disponível, em podcast, para escuta posterior:

https://www.facebook.com/diariodosulevora/ videos/1749757685086889/UzpfSTEyMTI3Nzk0MTIzNDk2ODoyMDAzNTI3NjA2MzQzMzE2/

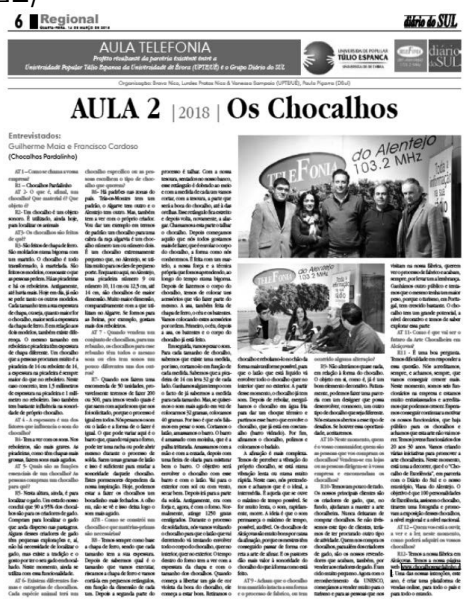

Figura 30. Notícia no Jornal Diário do Sul. Destaque para a "Aula Telefonia 2" (Março 2018) 


\section{AULA TELEFONIA 3}

\subsection{Tema: Os Sismos}

O tema escolhido para a Aula Telefonia 3 foi «Os Sismos», tendo sido entrevistado o Professor Rui Dias, docente do Departamento de Geociências da Escola de Ciências e Tecnologia da Universidade de Évora e Diretor do Centro de Ciência Viva de Estremoz

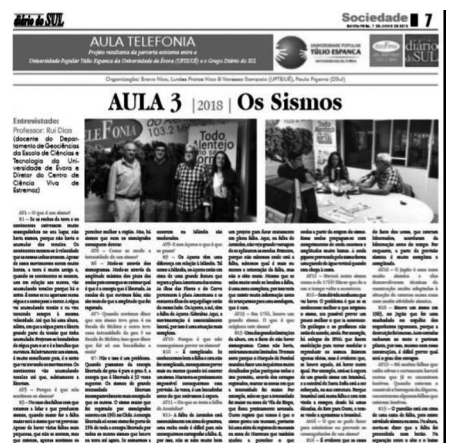

Figura 31. "Aula Telefonia 3" sobre "Os Sismos"

\section{ATIVIDADE INSTITUCIONAL}

PRESENÇA DA UPTE/UÉ EM SESSÕES ORGANIZADAS PELOS POLOS

\subsection{Sessão de abertura formal das atividades do Polo de Viana do Alentejo/2016}

A UPTE/UÉ integrou a mesa de abertura da sessão pública que assinalou a abertura das atividades educativas no Polo de Viana do Alentejo. Esta iniciativa teve lugar no Cine-Teatro Vianense (4 de Novembro, 2016).

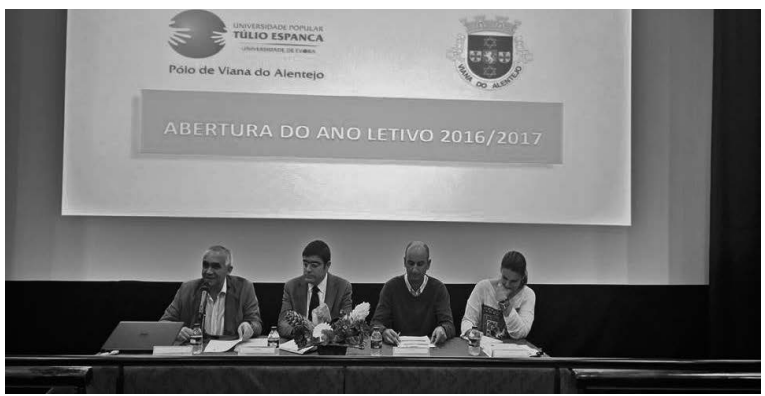

Figura 32. Abertura do ano letivo 2016/2017 no Polo de Viana do Alentejo da UPTE/UÉ 
PRESENÇA DA UPTE/UÉ EM SESSÕES ORGANIZADAS PELOS POLOS

6.2. Sessão de abertura formal das atividades do Polo de Canaviais/2017

Em 14 de Outubro de 2017, a UPTE/UÉ esteve presente na sessão de abertura do ano letivo do Polo de Canaviais. A sessão decorreu na Casa do Povo de Canaviais e contou com a presença da Presidente da Casa do Povo de Canaviais, do Presidente da Junta de Freguesia de Canaviais e do Diretor da UPTE/UÉ.

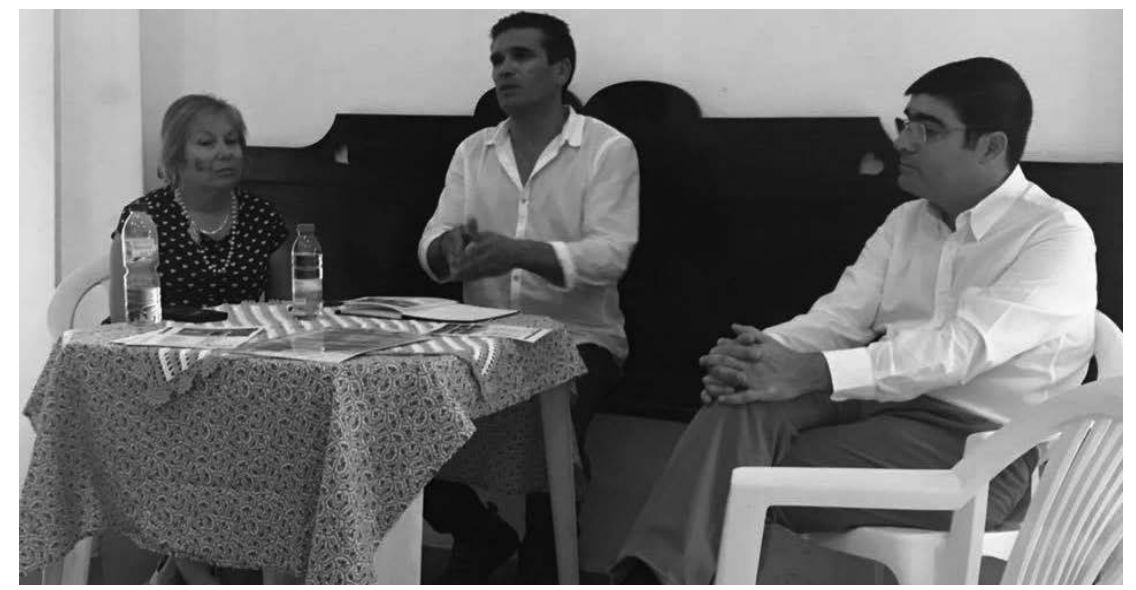

Figura 33.Sessão de Abertura do Ano Letivo no Polo de Canaviais da UPTE/UÉ

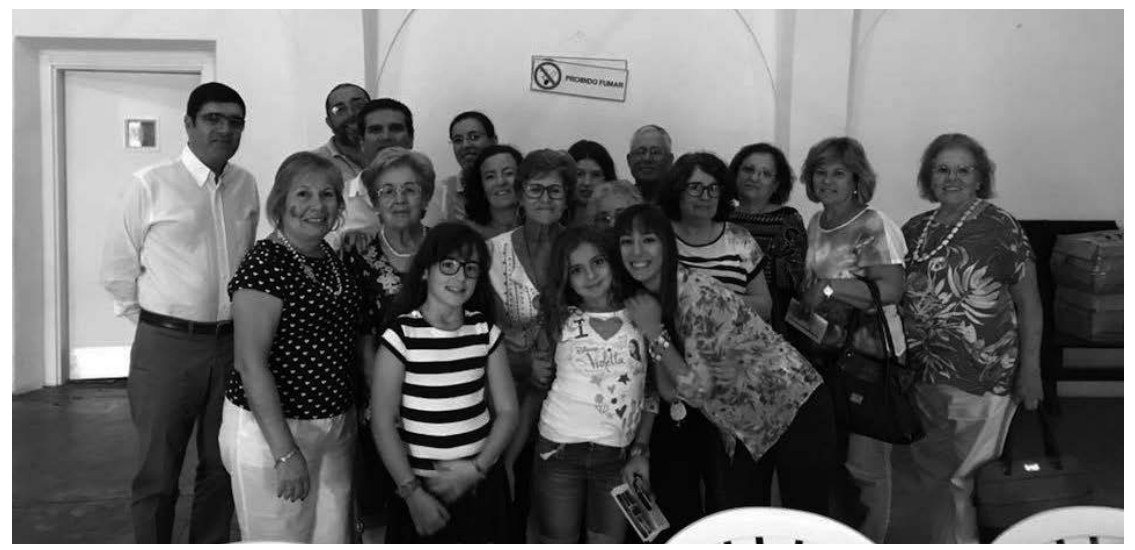

Figura 34. UPTE, alunos e professores do Polo de Canaviais da UPTE/UÉ 


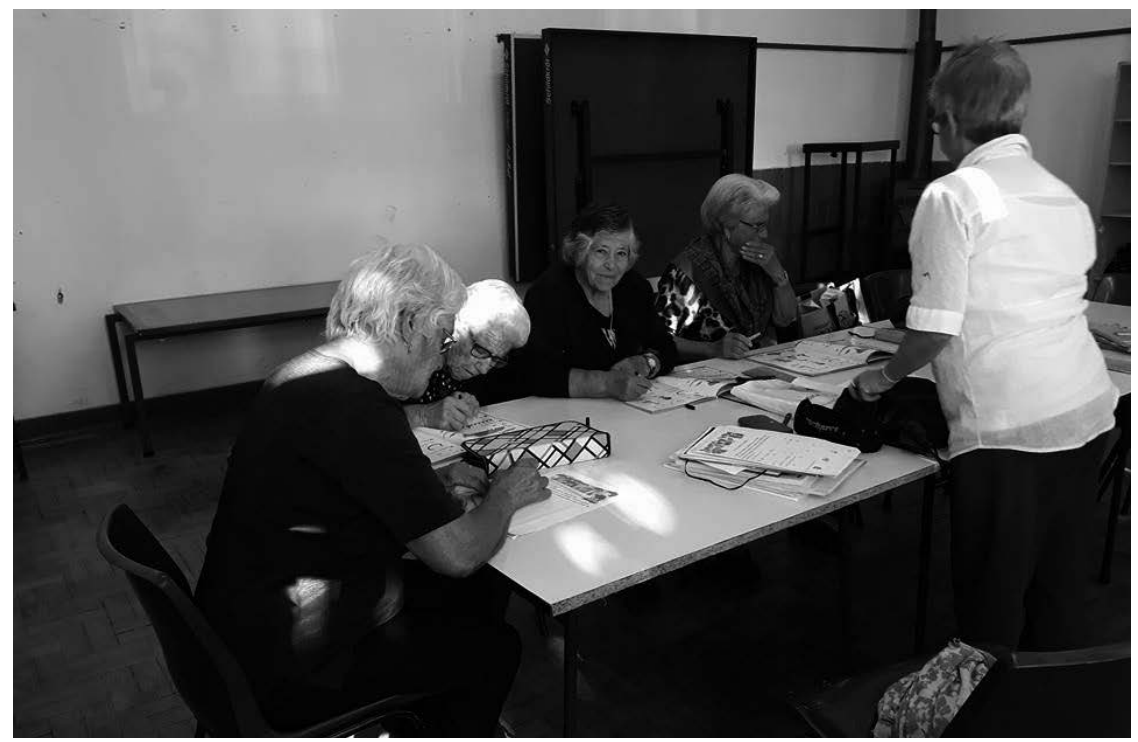

Figura 35. Aulas de Alfabetização (uma das atividades regulares do Polo de Canaviais da UPTE/UÉ; Quintas-feiras, entre as 10h e as 11h)

\section{PRESENÇA DA UPTE/UÉ EM SESSÕES ORGANIZADAS PELOS POLOS}

6.3. Sessão de encerramento formal das atividades do Polo de Canaviais/2017

Em 8 de Julho de 2017 , a UPTE/UÉ esteve presente na festa de final de ano letivo do Polo de Canaviais, em Évora.
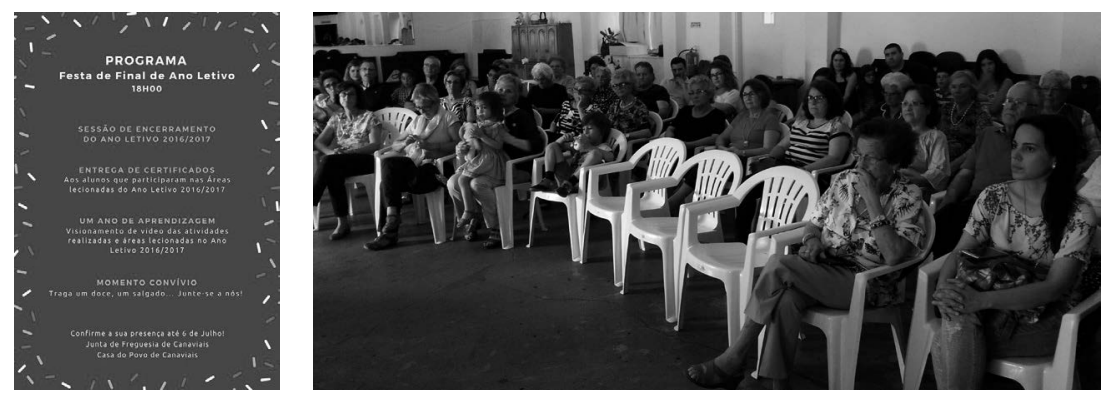

Figura 36. Público presente na Festa de Final de Ano Letivo no Polo de Canaviais da UPTE/UÉ 


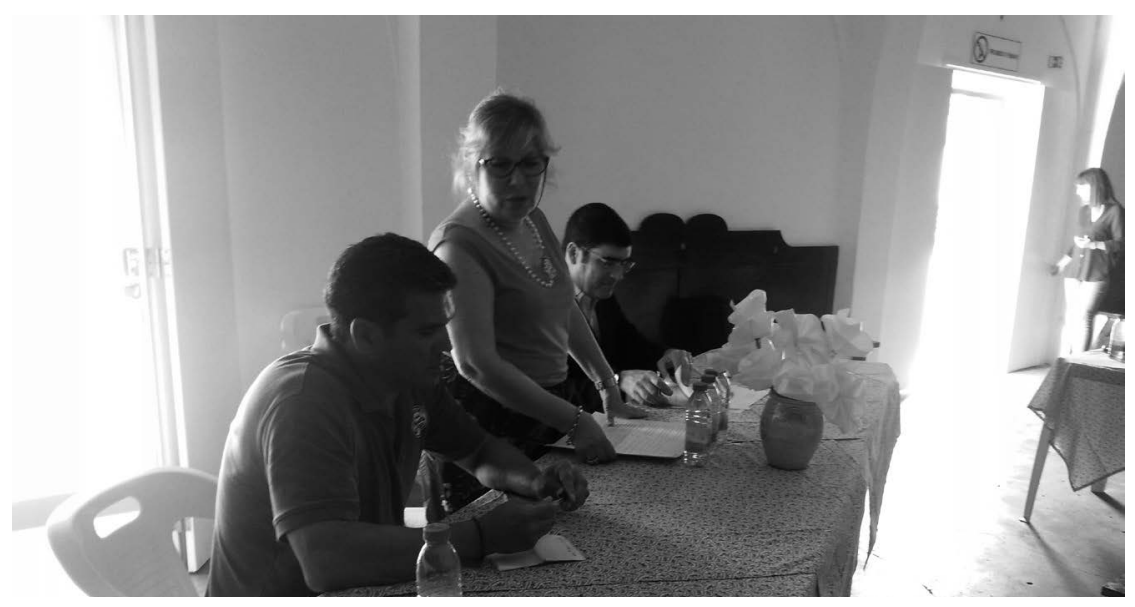

Figura 37. Sessão de Abertura

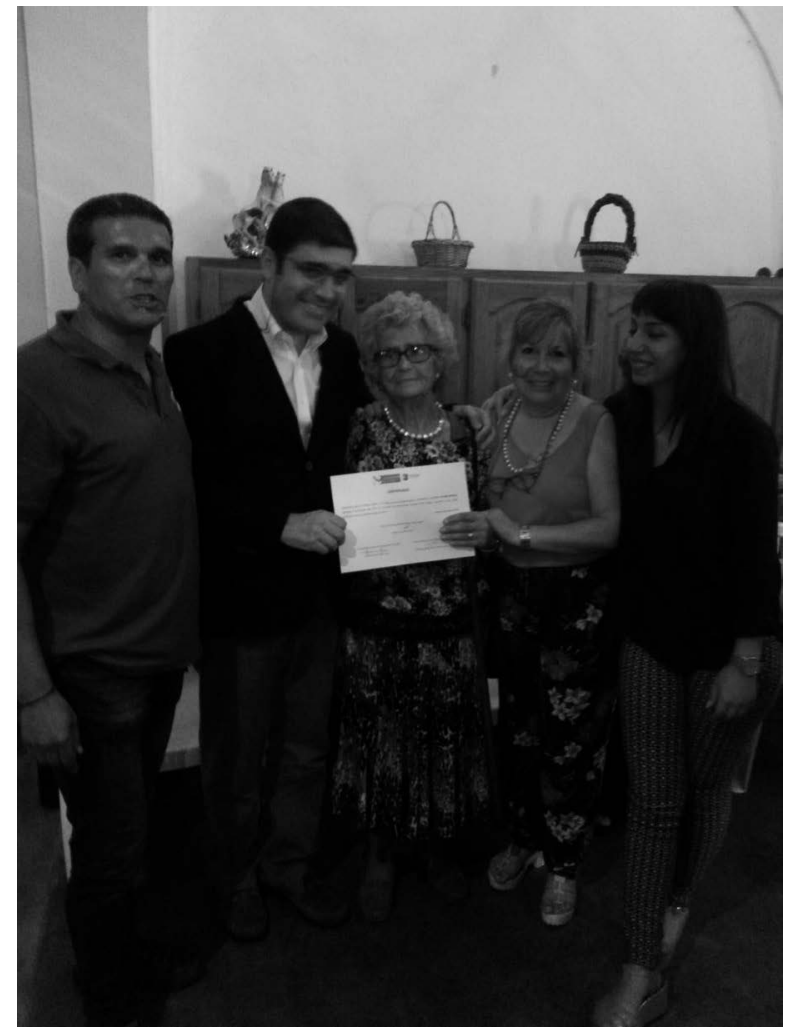

Figura 38. Entrega dos certificados aos alunos do Polo de Canaviais da UPTE/UÉ 


\section{PRESENÇA DA UPTE/UÉ EM SESSÕES ORGANIZADAS PELOS POLOS}

6.4. Sessão de encerramento formal das atividades do Polo de Portel/2017

No dia seguinte, em 9 de Julho de 2017, a UPTE/UÉ também marcou presença na festa de final de ano letivo do Polo de Portel.

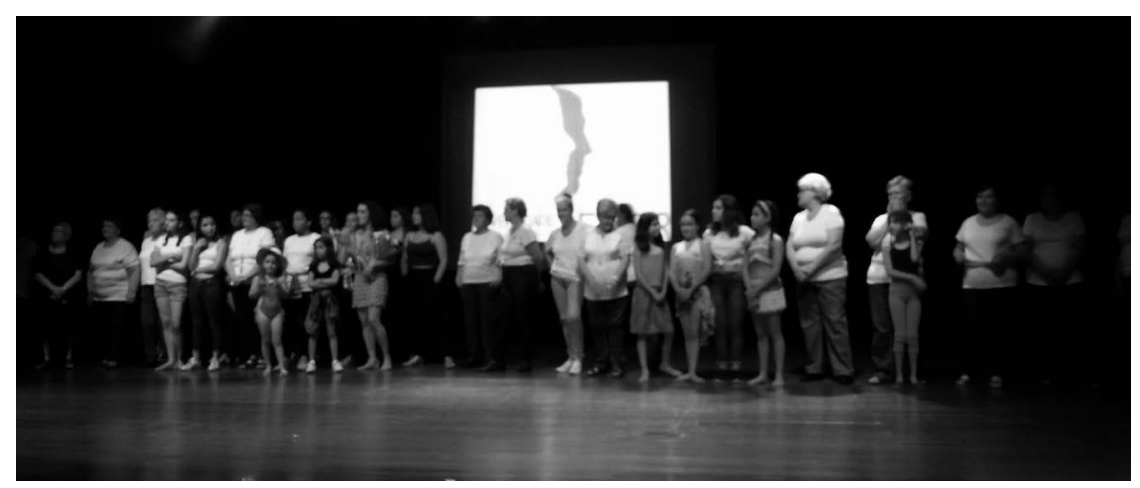

Figura 39. Grupo de participantes na Festa de Final de Ano Letivo no Polo de Portel da UPTE/UÉ

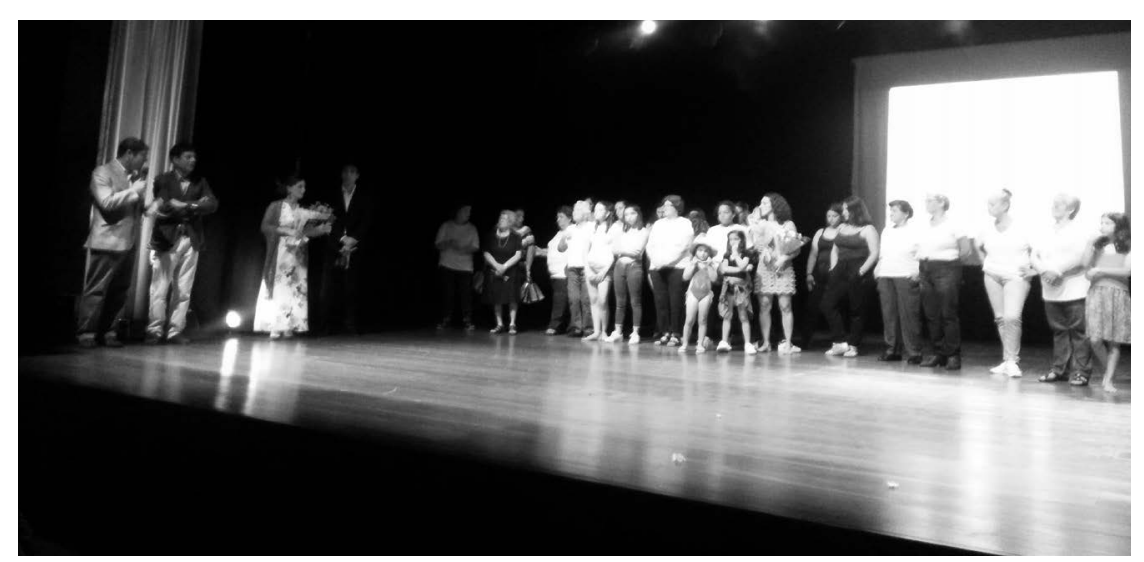

Figura 40. Responsáveis institucionais presentes na Festa de Final de Ano no Polo de Portel da UPTE/UÉ 


\section{PRESENÇA DA UPTE/UÉ EM SESSÕES ORGANIZADAS PELOS POLOS}

6.5. Sessão de encerramento formal das atividades do Polo de Canaviais/2018

Em 30 de Junho de 2018 , a UPTE/UÉ esteve presente na festa de final de ano letivo do Polo de Canaviais, em Évora.

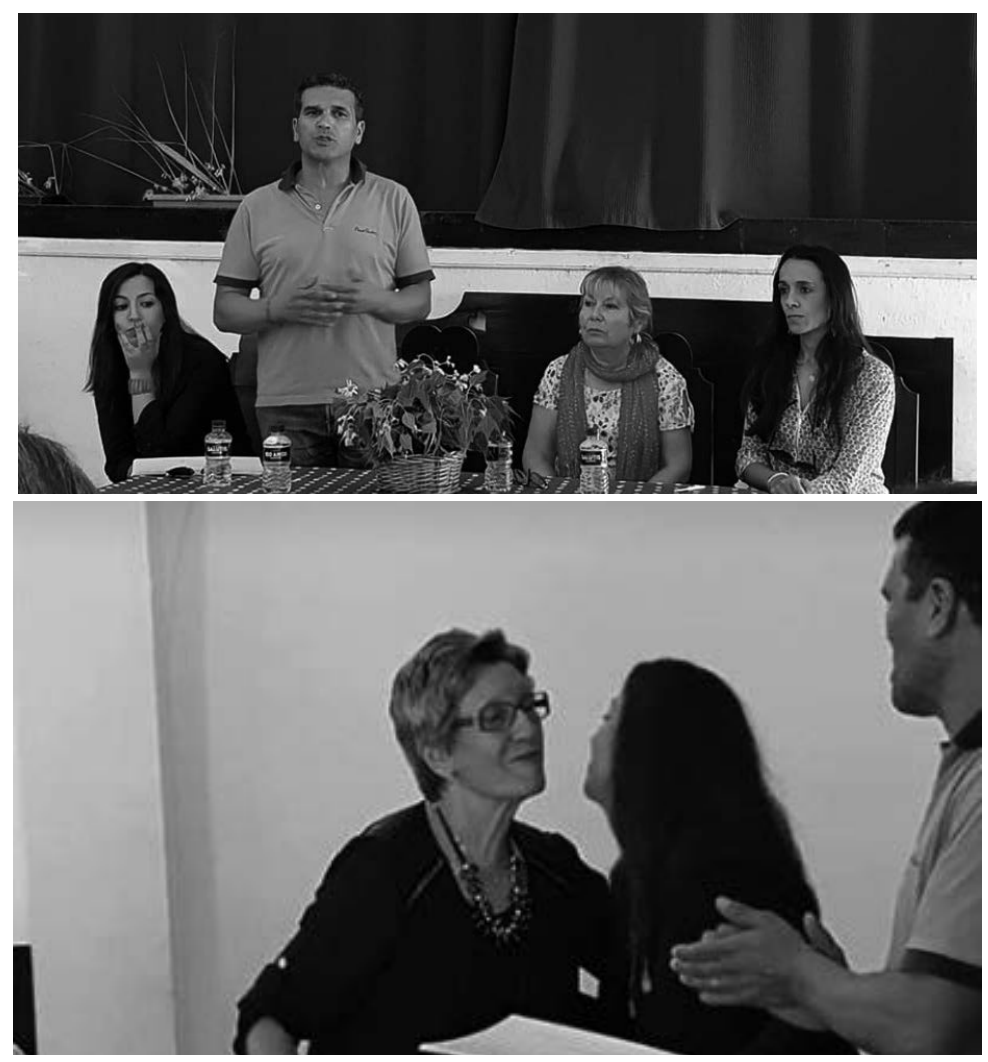

Figura 41. Festa de final de ano letivo 2017/2018 do Polo de Canaviais da UPTE/UÉ

\section{REUNIÕES DE TRABALHO/COORDENAÇÃO}

6.6. Reunião de preparação para a abertura do Polo de Barrancos da UPTE/UÉ em Viana do Alentejo

Em 3 de Abril de 2017, realizou-se uma reunião de apresentação do projeto da Universidade Popular Túlio Espanca/UÉ, em Viana do Alentejo. 
Na reunião estiveram presentes: o Presidente da Câmara Municipal de Viana do Alentejo, o Presidente da Câmara Municipal de Barrancos, o Diretor da UPTE/UÉ as equipas técnicas de cada uma das instituições e uma aluna do $3 .^{\circ}$ ano da Licenciatura em Ciências da Educação da Universidade de Évora que, sendo residente em Barrancos, tem apoiado e estado presente neste processo de abertura de um polo da UPT/UÉ na sua terra.

Através da apresentação do trabalho que é realizado no Polo da UPTE/ UÉ, em Viana do Alentejo, procurou-se sensibilizar e informar o Município de Barrancos, tendo em vista a abertura de eventual Polo da UPTE/ UÉ, em Barrancos.

Foi elaborado um protocolo de cooperação entre a UPTE/UÉ e o Município de Barrancos que será a entidade promotora do novo Polo, à semelhança do que já tinha ocorrido nos municípios de Alandroal, Portel, Viana do Alentejo e em Évora (Bairro de Canaviais e São Miguel de Machede).
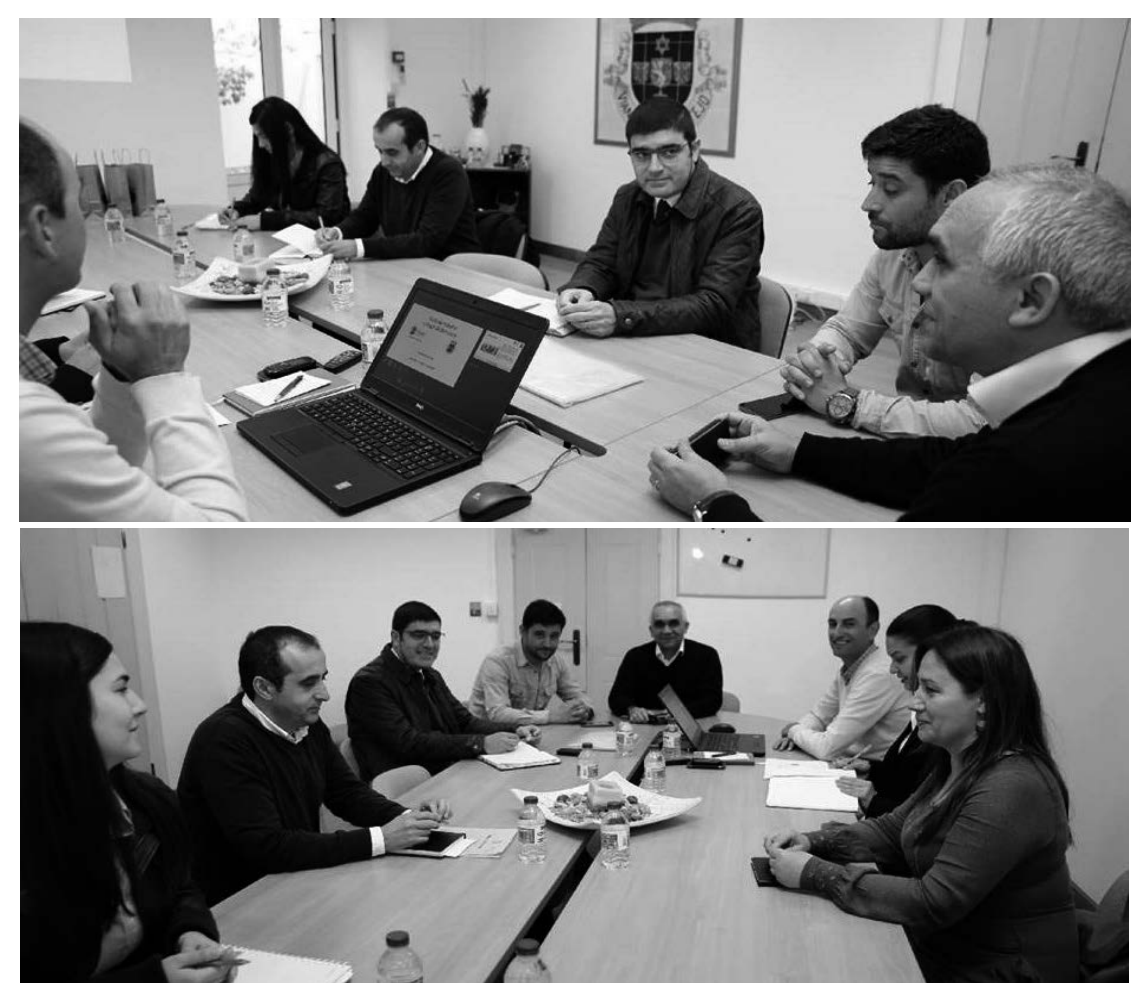

Figura 42. Delegação de Barrancos visita Viana do Alentejo no âmbito da UPTE/UÉ

O processo de cooperação, entre a UPTE/UÉ e o município de Barrancos, contou com a participação da estudante do $3 .^{\circ}$ ano da 
Licenciatura em Ciências da Educação, Alexandra Bergano, um elo de ligação entre a academia e a autarquia (na foto, em baixo, a primeira do lado esquerdo).

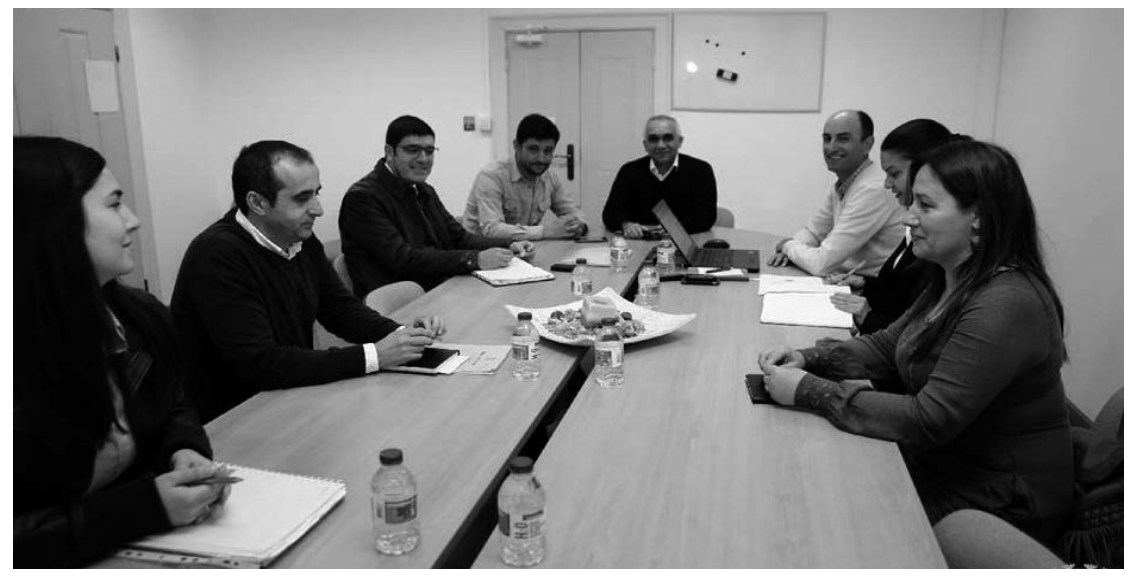

Figura 43. Reunião de trabalho tendo em vista a abertura de um Polo da UPTE/UÉ no Município de Barrancos

(3 de Abril de 2017)

\section{REUNIÕES DE TRABALHO/COORDENAÇÃO}

\subsection{Participação da UPTE/UÉ em reunião de trabalho em Lisboa}

Em Julho de 2017, o Diretor da UPTE/UÉ, Professor Doutor Bravo Nico, por indicação da Senhora Reitora da Universidade de Évora, participou numa reunião em Lisboa, no Ministério da Saúde. O objetivo da presença do representante da UPTE/UÉ foi assegurar as condições para concretizar uma colaboração na estrutura do Plano Nacional de Literacia em Saúde, em preparação, no Ministério da Saúde.

\section{REUNIÕES DE TABALHO/COORDENAÇÃO}

\subsection{Reunião de preparação da abertura do Polo de Reguengos de Monsaraz}

Tendo em vista a celebração de um protocolo para a instituição de um novo Polo em Reguengos de Monsaraz, decorreu, em 4 de Julho de 2017, uma reunião de trabalho entre o Diretor da UPTE/UÉ (Professor Doutor Bravo Nico) e o Presidente do Município de Reguengos de Monsaraz (Dr. José Gabriel Calixto). Na reunião, entre outros elementos, há a destacar a participação da Técnica Superior Anabela Caeiro (ex-aluna da Universidade de Évora, Mestre em Ciências da Educação/Especialização em Educação Comunitária 


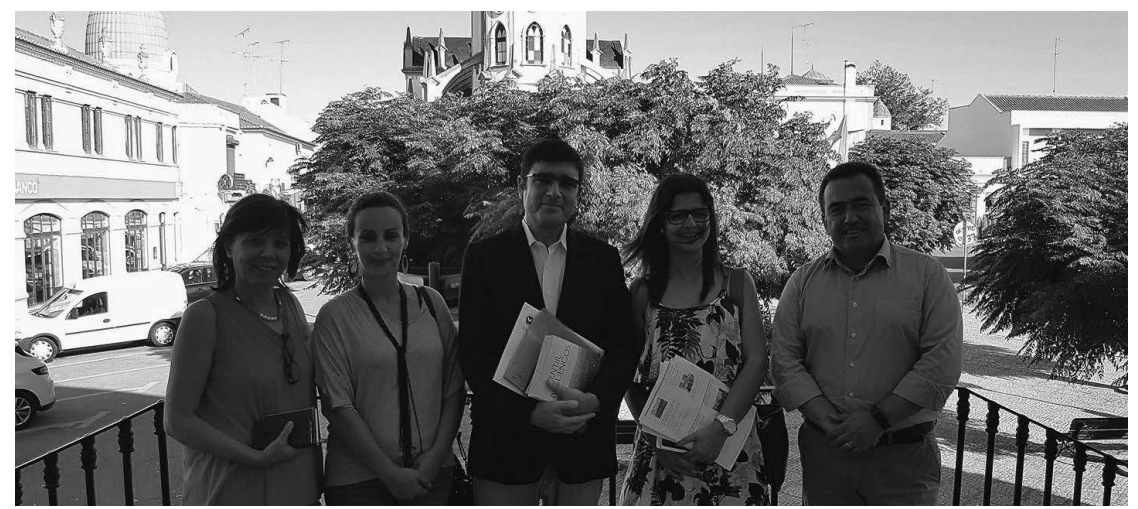

Figura 44. Participantes da reunião entre entre a UPTE/ UÉ e o Município de Reguengos de Monsaraz

(Da esq. para a dir.: A Vereadora Joaquina Margalha, a Técnica Anabela Caeiro, o Diretor da UPTE Prof. Bravo Nico, a Técnica Inês Bento e o Presidente do Município Dr. José Gabriel Calixto; Foto: CMReguengos de Monsaraz)

\section{REUNIÕES DE TRABALHO/COORDENAÇÃO}

\subsection{Reunião com os Polos - Balanço do Ano (UPTE/UÉ; Coordena- dores e Técnicos de cada Polo)}

Em 12 de Julho de 2017, teve lugar, na Sala de Docentes do Colégio do Espírito Santo, na Universidade de Évora, uma reunião de trabalho entre os vários coordenadores dos Polos da UPTE/UÉ.

Essa reunião permitiu efectuar um balanço do trabalho efectuado em cada Polo, identificar potencialidades e fragilidades e definir atividades para o próximo ano letivo.

A curto prazo será elaborado um livro conjunto, com o contributo dos vários Polos. O conteúdo desse livro incidirá sobre o trabalho de Educação Popular concretizado em cada um dos Polos/territórios.

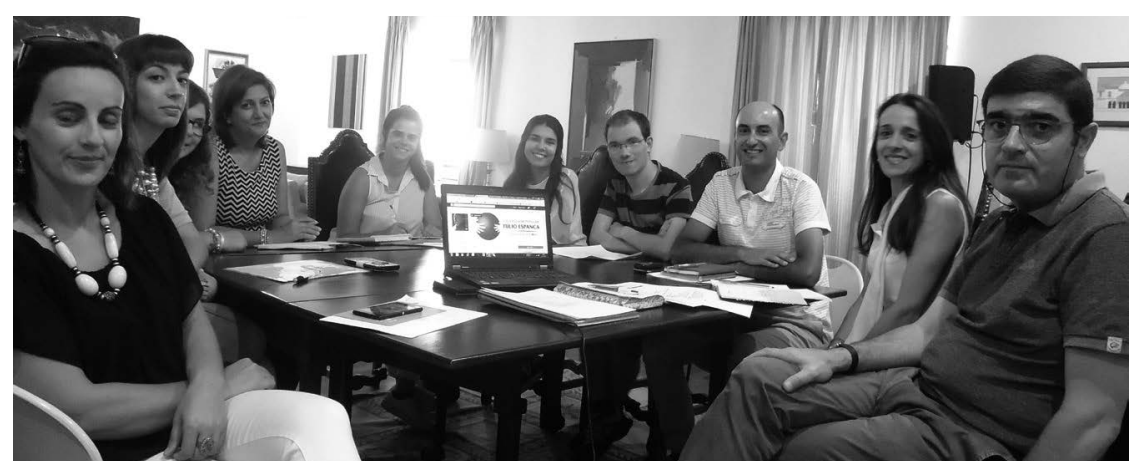

Figura 45. Reunião entre os vários Polos da UPTE/UÉ 


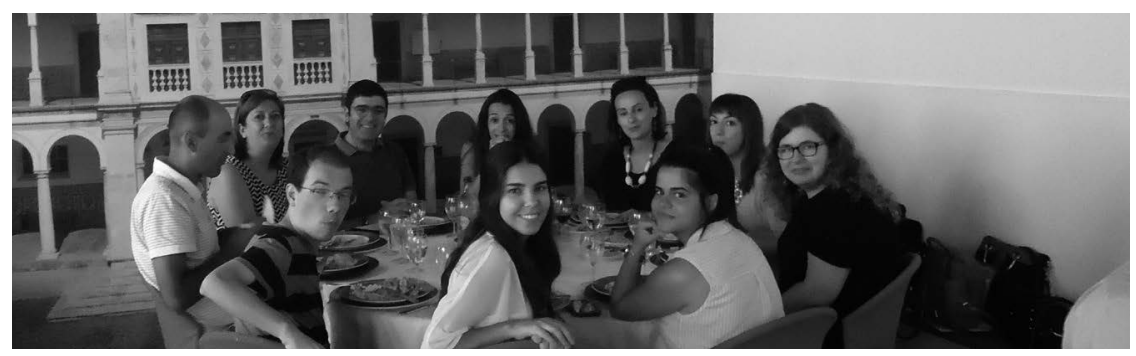

Figura 46. Almoço de confraternização após a reunião de trabalho

\section{REUNIÕES DE TRABALHO/COORDENAÇÃO}

\subsection{Reuniões deslocalizadas em cada um dos Polos}

No mês de Janeiro de 2018, foram realizadas reuniões de trabalho, em cada polo, de acordo com a seguinte calendarização:

QUADRO 3. REUNIÕES DE TRABALHO COM OS POLOS/JANEIRO 2018

\begin{tabular}{ccccccc}
\hline Janeiro & $\mathbf{3}$ & $\mathbf{4}$ & $\mathbf{5}$ & $\mathbf{9}$ & $\mathbf{1 6}$ & $\mathbf{1 9}$ \\
\hline Local & Canaviais & Portel & Barrancos & Viana do & Alandroal & Reguengos \\
& & & & Alentejo \\
& & & & São Miguel de \\
Machede & & \\
& & & \multicolumn{3}{c}{ de Monsaraz } \\
\hline
\end{tabular}

Na sequência destas reuniões, foi enviado um memorando, com uma proposta de atividades comuns a realizar, durante este ano.

Nesta data, todos os sete polos parceiros da rede da Universidade Popular Túlio Espanca/Universidade de Évora estavam ativos e os polos de Barrancos e de Reguengos de Monsaraz iniciavam a sua atividade, com o apoio e a colaboração dos restantes Polos da UPTE/UÉ.

\section{REUNIÕES DE TRABALHO/COORDENAÇÃO}

\subsection{Reunião de coordenação geral na Universidade de Évora}

Em 14 de Fevereiro de 2018, realizou-se uma reunião de coordenação geral com a presença dos Polos. Esta reunião teve lugar no Colégio Pedro da Fonseca, na Universidade de Évora. Na reunião, definiram-se as atividades a realizar em conjunto.

No sentido de se proceder à maior divulgação possível da atividade de cada Polo, definiu-se um circuito de comunicação com os Polos, sugerindo-se que possam, antecipadamente, informar sobre:

(i) a atividade que querem destacar, em cada mês; 
(ii) uma pequena nota das atividades realizadas, em cada mês, acompanhadas por uma foto ilustrativa.

No ano de 2018, foram comemorados os dias da UPTE/UÉ e de cada um dos seus Polos, com a organização de atividades diversificadas, abertas aos restantes Polos.

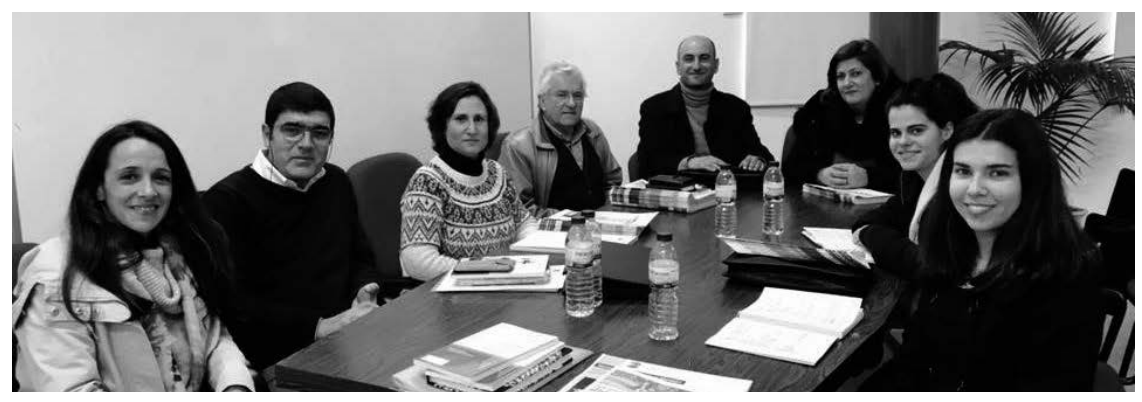

Figura 47. Reunião de Coordenação Geral

\section{ALARGAMENTO DA REDE DE POLOS DA UPTE/UÉ}

6.12. Sessão pública de assinatura do Protocolo em Barrancos/Abertura do Polo da UPTE/UÉ em Barrancos

Em 1 de Julho de 2017, teve lugar a sessão pública de assinatura do protocolo entre a Reitoria da Universidade de Évora, o Diretor da Universidade Popular Túlio Espanca e o Município de Barrancos. Nesta cerimónia, participou a estudante do Curso de Licenciatura em Ciências da Educação, Alexandra Bergano, que participou em todo de preparação do protocolo entre a Universidade de Évora e a Câmara Municipal de Barrancos.

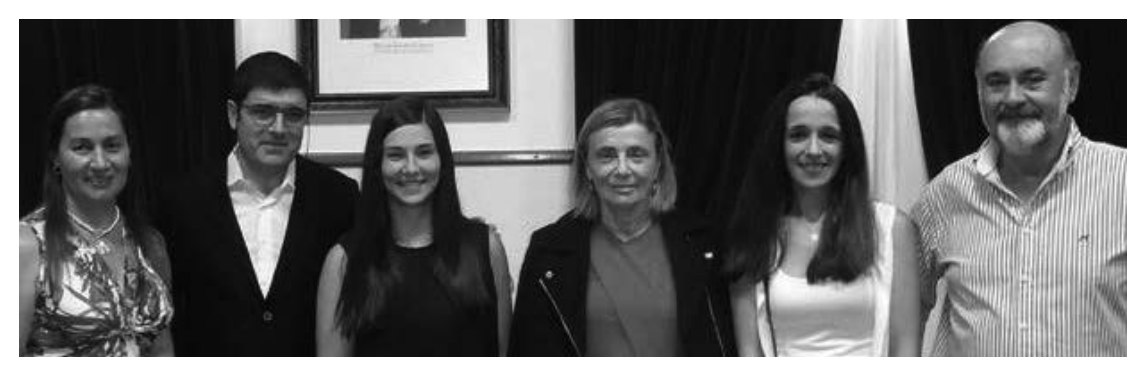

Figura 48. Sessão pública de assinatura do protocolo entre a UPTE da Universidade de Évora e o Município de Barrancos (1 de Julho de 2017)

Da esq. para a dir.: Vice-Presidente do Município Dra. Isabel Sabino; Diretor da UPTE/ UÉ Professor Doutor Bravo Nico; a estudante Alexandra Bergano; Senhora Reitora da Universidade de Évora, Professora Doutora Ana Costa Freitas; Professora Doutora Lurdes Pratas Nico e o Presidente do Município Dr. António Pica Tereno 


\section{ALARGAMENTO DA REDE DE POLOS DA UPTE/UÉ}

\subsection{Sessão pública de assinatura do Protocolo em Reguengos de Monsaraz/ Abertura do Polo da UPTE/UÉ em Reguengos de Monsaraz}

Em 1 de Setembro de 2017, teve lugar a sessão pública de assinatura do protocolo entre a Reitoria da Universidade de Évora, o Diretor da Universidade Popular Túlio Espanca e o Município de Reguengos de Monsaraz.

O processo de cooperação, entre a UPTE/UÉ e o município de Reguengos de Monsaraz, contou com a participação de uma estudante, Anabela Caeiro, Mestre em Ciências da Educação/Especialização Educação Comunitária, na Universidade de Évora, atualmente inscrita no Curso de Doutoramento em Ciências da Educação. A Anabela Caeiro foi um elo de ligação entre a academia e a autarquia de Reguengos de Monsaraz, uma vez que esta exercia funções na autarquia, como Técnica Superior, na área socioeducativa. Desta forma, a estudante, teve possibilidade de aplicar, na prática, o que adquiriu na formação e investigação, com resultados evidentes, como foi a criação do Polo da UPTE/UÉ em Reguengos de Monsaraz. A sessão decorreu na Biblioteca Municipal de Reguengos de Monsaraz, onde funciona o polo da UPTE/UÉ. As boas vindas foram dadas pelo Presidente do Município e pela Tuna do Polo de Viana do Alentejo da UPTE/UÉ.

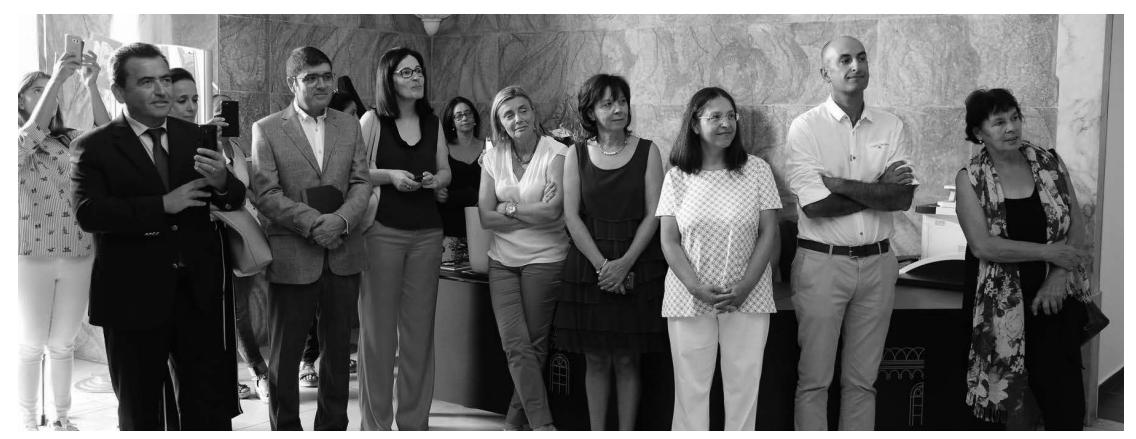

Figura 49. Representantes institucionais 


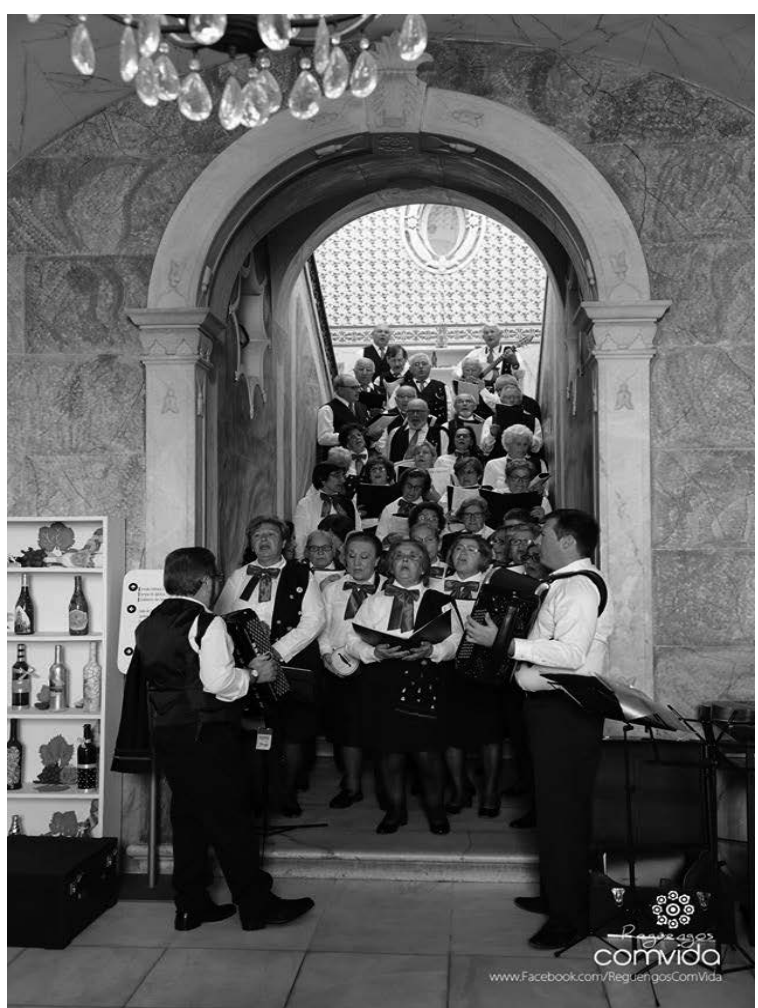

Figura 50. Sessão de Boas Vindas na entrada da Biblioteca Municipal de Reguengos/Atuação da Tuna do Polo de Viana do Alentejo

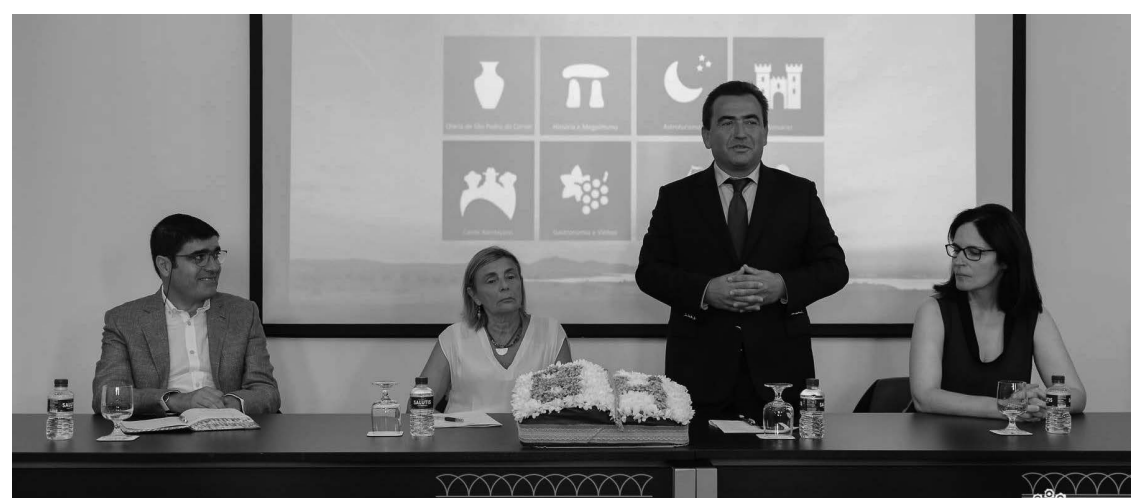

Figura 51. Sessão pública de assinatura do protocolo entre a UPTE da Universidade de Évora e o Município de Reguengos de Monsaraz (1 de Setembro de 2017)

Da esq. para a dir.: Diretor da UPTE/UÉ Professor Doutor Bravo Nico; Senhora Reitora da Universidade de Évora Professora Doutora Ana Costa Freitas; Sr. Presidente da Câmara Municipal de Reguengos de Monsaraz, Dr. José Calixto e a Sra. Diretora Regional da Cultura, Dra. Ana Paula Amendoeira 


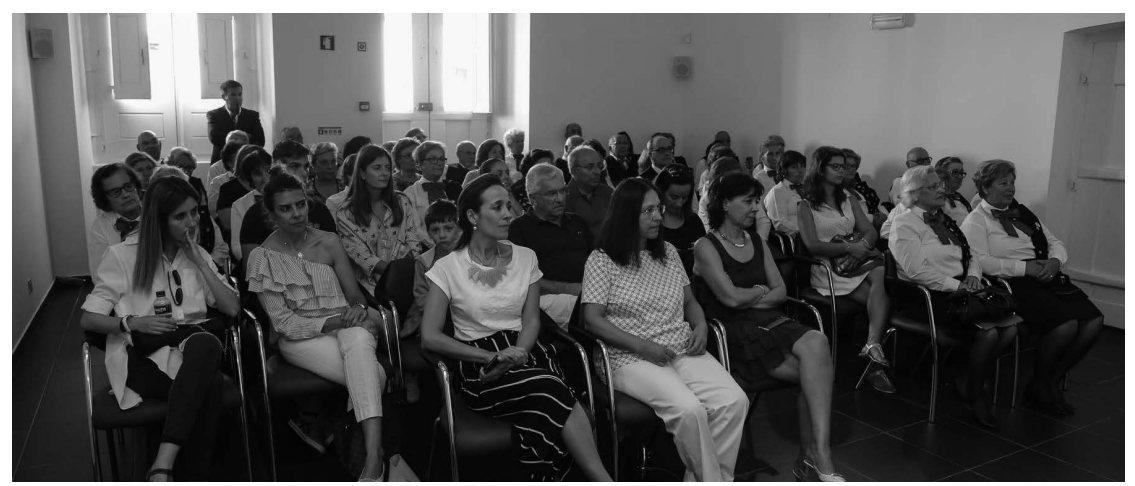

Figura 52. Público presente na sessão de assinatura do protocolo entre a UPTE da Universidade de Évora e o Município de Reguengos de Monsaraz (1 de Setembro de 2017)

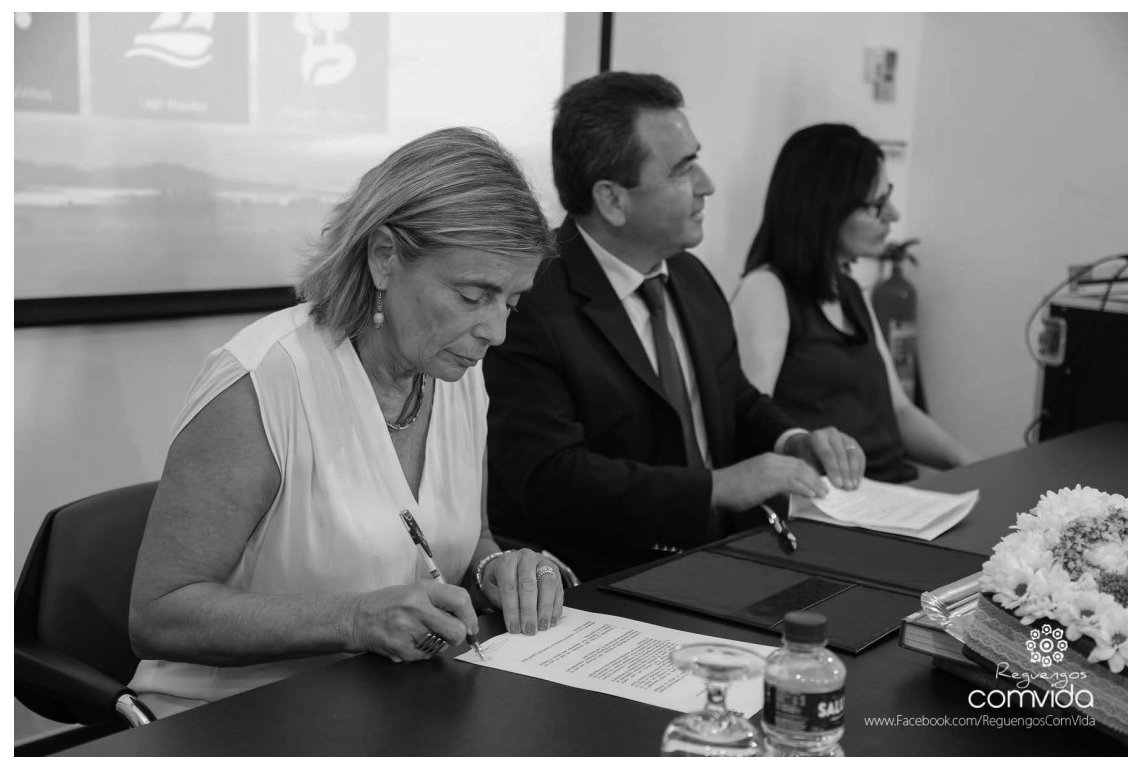

Figura 53. Momento da assinatura formal do Protocolo de Cooperação

\section{AFETAÇÃO DE MEMBROS À EQUIPA DA UPTE/UÉ}

6.14. Contratação de uma Bolseira de Investigação/Antiga aluna da Universidade de Évora, Licenciada em Ciências da Educação

Nos meses de Outubro e Dezembro de 2017, decorreu o processo de contratação da ex-aluna da Universidade de Évora, Vanessa Sampaio, que se licenciou em Ciências da Educação, na Academia Eborense 
e com Mestrado em Serviço Social, no Instituto Superior de Ciências Educativas.

O procedimento de contratação teve início em 12 de Outubro de 2017 e a contratação, como Bolseira de Investigação, na Universidade de Évora, concretizou-se a 15 de Dezembro de 2017.

Antes de iniciar a sua atividade como Bolseira de Investigação, Vanessa Sampaio exerceu funções como Técnica Superior na SUÃO - Associação de Desenvolvimento Comunitário/Escola Comunitária de São Miguel de Machede.

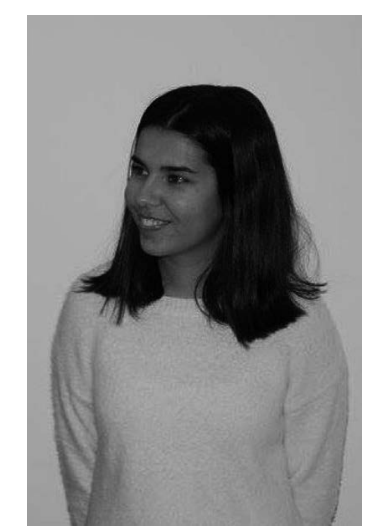

Figura 54. Vanessa Sampaio, Bolseira de Investigação, na Universidade de Évora

\section{ATIVIDADES PROMOVIDAS POR ESTUDANTES}

\section{PALESTRA 1}

\subsection{Tema: "O que dizem os nossos cães?”}

No âmbito da disciplina de $3^{\circ}$ ano do plano de estudos da Licenciatura em Ciências da Educação, a aluna Cláudia Gaio planificou e organizou uma palestra sobre o tema “O que dizem os nosso cães?”.

O objetivo desta iniciativa foi consciencializar as pessoas para os direitos dos animais, com especial atenção aos animais de estimação.

A palestra teve lugar no Cineateatro Vianense, em 11 de Julho, entre as $14 \mathrm{~h} 30$ e as $17 \mathrm{~h} 30$, e nela participaram os alunos do Polo e a comunidade em geral. A entidade responsável pela sua dinamização foi o Polo de Viana do Alentejo da UPTE/UÉ, com a intervenção da aluna Cláudia Gaio, residente na localidade de Viana do Alentejo. 


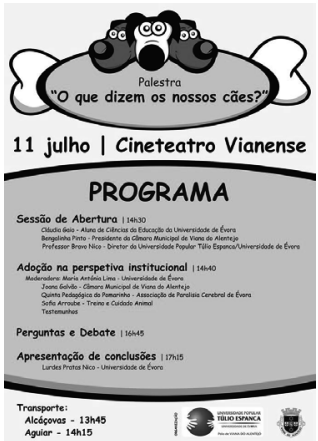

Figura 55.Programa da Palestra "O que dizem os nosso cães”

\section{PALESTRA 2}

\subsection{Tema: "Jeitinho Brasileiro"}

Três alunas brasileiras, em mobilidade internacional/Erasmus a frequentar unidades curriculares do Curso de Licenciatura em Ciências da Educação da Universidade de Évora, organizaram e dinamizaram uma atividade de educação popular denominada "Jeitinho Brasileiro"

Esta atividade teve como destinatários 10 alunas do Curso de Educação Comunitária/Educação de Adultos promovido pela Escola Comunitária de São Miguel de Machede/SUÃO - Associação de Desenvolvimento Comunitário e realizou-se em 24 de maio de 2017, nas instalações da Escola Comunitária.

O objetivo foi dar a conhecer a cultura brasileira e dinamizar uma atividade de educação popular em contexto real. Dessa forma, as alunas puderam aplicar, na prática, os conhecimentos teóricos adquiridos nas aulas, no âmbito das disciplinas que integram o seu currículo.

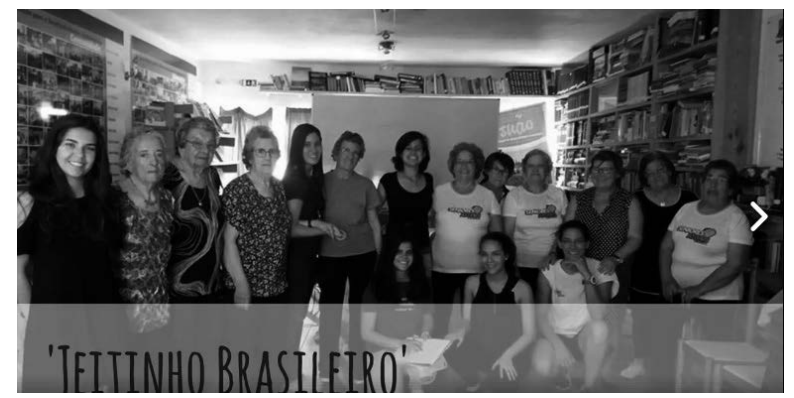

Figura 56. Atividade "Jeitinho Brasileiro" preparada pelas alunas brasileiras Maira Trentin, Júlia Santos e Nayara Sant 'Anna, na Escola Comunitária de São Miguel de Machede 


\section{ATIVIDADES DE EDUCAÇÃO POPULAR}

\section{PROMOVIDAS PELOS POLOS}

\subsection{Atividade Musical: II Grande Audição da Escola de Música de Hortinhas do Pólo de Alandroal e a atuação do Grupo "Trigueirão no Relheiro"}

A UPTE/UÉ esteve presente, em 4 de Fevereiro de 2017, no Fórum Cultural Transfronteiriço de Alandroal, a convite do Pólo de Alandroal da UPTE/UÉ. Aí ocorreu inauguração de uma exposição de Rui Aleixo intitulada “Ganas de Ferro”, seguindo-se a II Grande Audição da Escola de Música de Hortinhas do Pólo de Alandroal da UPTE/UÉ e a atuação do Grupo “Trigueirão no Relheiro”. Uma iniciativa que ajuda a preservar a cultura e música populares.

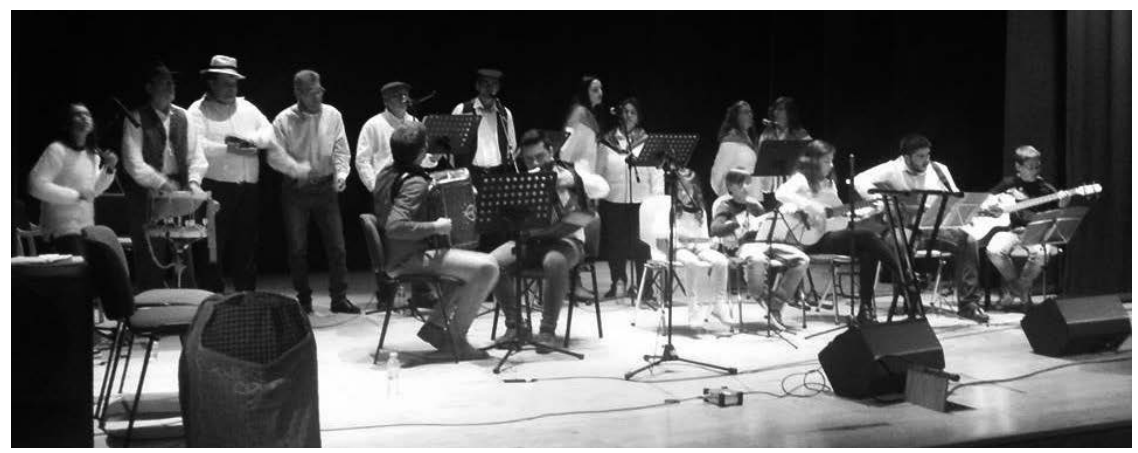

Figura 57. Atuação do Grupo “Trigueirão no Relheiro”

\section{PROMOVIDAS PELA UPTE/UÉ}

\subsection{Projeto "Escola da Cidade"}

Retomou-se o projeto "Escola da Cidade" desenvolvido em 2014 com alunos da Licenciatura em Ciências da Educação da Universidade de Évora. Trata-se de um projeto que tem como objetivo "levar" a possibilidade de construção e de realização de atividades de aprendizagem em contexto mais familiar e doméstico, no domicílio dos que estejam interessados em aprender. Presentemente, o território de intervenção é o Centro Histórico da cidade de Évora.

A estratégia de contato junto das pessoas a envolver no projeto passa por 3 etapas principais:

1. ${ }^{a}$ etapa: Realização de uma reunião exploratória com as pessoas identificadas, de natureza muito informal e durante a qual os estudantes possam: 
- estabelecer uma relação de amizade e confiança, com todos os envolvidos;

- identificar alguns dos mais importantes aspetos da vida pessoal, familiar, cívica e social de cada pessoa (o que fez, quais as coisas mais importantes, os projetos de maior sucesso, as coisas que, ainda, gostariam de realizar,...)

- durante essas reuniões, os alunos recolhem o máximo de informação possível, no pressuposto de que a mesma poderá dar-lhes pistas de possíveis interesses, projetos e atividades de aprendizagem.

2. ${ }^{a}$ etapa: Após as reuniões, os alunos reúnem-se entre si, trocam as informações e fazem uma seleção dos aspetos mais salientes, sugerindo possíveis projetos de aprendizagem que os mesmos podem suscitar, junto dos coordenadores do projeto.

3. ${ }^{a}$ etapa: A partir daí, definem-se os objetivos, as estratégias, os recursos necessários e a calendarização.

\section{PROMOVIDAS PELA UPTE/UÉ}

\subsection{Visita de Estudo à Universidade de Évora /2018}

A UPTE/UÉ organizou uma visita de estudo à Universidade de Évora. Esta visita, realizada em 14 de Março de 2018, destinou-se aos estudantes/ participantes dos sete Polos da UPTE/UÉ e teve como lugar central um dos edifícios mais importantes da academia: o Colégio do Espírito Santo (parte da manhã).

Da parte da tarde, em resultado da parceria com o grupo de comunicação social Diário do SUL/Rádio Telefonia do Alentejo, a visita decorreu nas instalações do Grupo. O seu Diretor Executivo, Paulo Piçarra (e os seus colaboradores), teve a amabilidade de receber o grupo. Aí, pudemos escutar a história da fundação e da existência do jornal há já quase meio século (fez, este ano, 49 anos). Os estudantes dos vários Polos da UPTE/ UÉ ficaram a saber como e onde se faz o Diário do Sul, o único jornal diário do Alentejo.

Cada participante recebeu um livro sobre a água (edição do Centro UNESCO/Aldeia das Ciências, com o apoio da Caixa de Crédito Agrícola e do Diário do Sul) e um exemplar do jornal desse dia.

O Diário do Sul faz parte da história da UPTE/UÉ porque, juntamente com outras entidades, esteve presente na sessão de abertura desta Escola Popular, em 16 de Dezembro de 2009, dia em que assinaria um protocolo de cooperação com a Universidade de Évora.

Esta visita foi preparada e desenvolvida com a ajuda e apoio de vários estudantes e docentes da Licenciatura em Ciências da Educação que participaram, ativamente, na organização das atividades da Universidade Popular Túlio Espanca. Os estudantes partilharam experiências, 
contaram como é a sua vida de estudante, aprenderam coisas novas através do contacto com outras gerações e tiveram a possibilidade de partilhar os seus conhecimentos e experiências na cidade e na academia.

Programa da Visita de Estudo

10:00h - Acolhimento na Sala dos Actos do Colégio do Espírito Santo

10:30h - Sessão de Boas Vindas

11:00h - Visita ao Colégio do Espírito Santo

- Sala dos Actos /Salas dos Claustros/ Antigo Refeitório/ Bar/ Centro do Mundo

- Capela/ Biblioteca Geral da Universidade de Évora/ Sala de Docentes 12:30h: Deslocação para o Almoço

13:00h - Almoço no Refeitório do Colégio Luís Verney

14:30h - Visita ao Grupo de Comunicação Social/Diário do SUL

15:50h - Apresentação da Aula Telefonia n. ${ }^{\circ} 2$ "O Chocalho"

16:00h - Final da Visita de Estudo

Estiveram presentes, nesta atividade educativa, duas centenas de participantes dos sete polos e estudantes/voluntários da Licenciatura em Ciências da Educação.

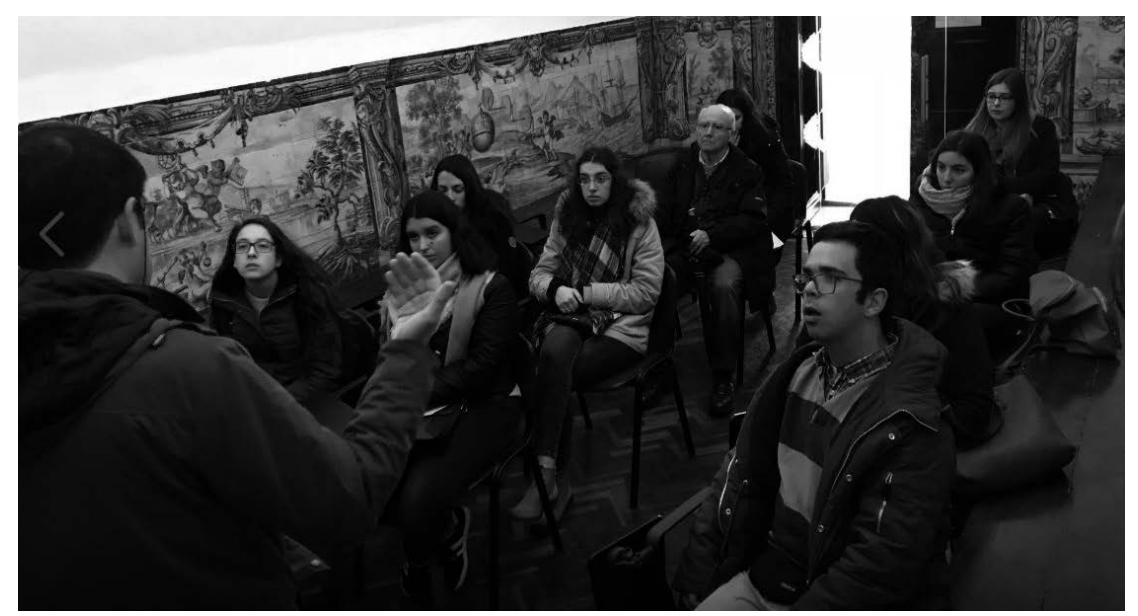

Figura 58. Estudantes no Colégio do Espírito Santo 

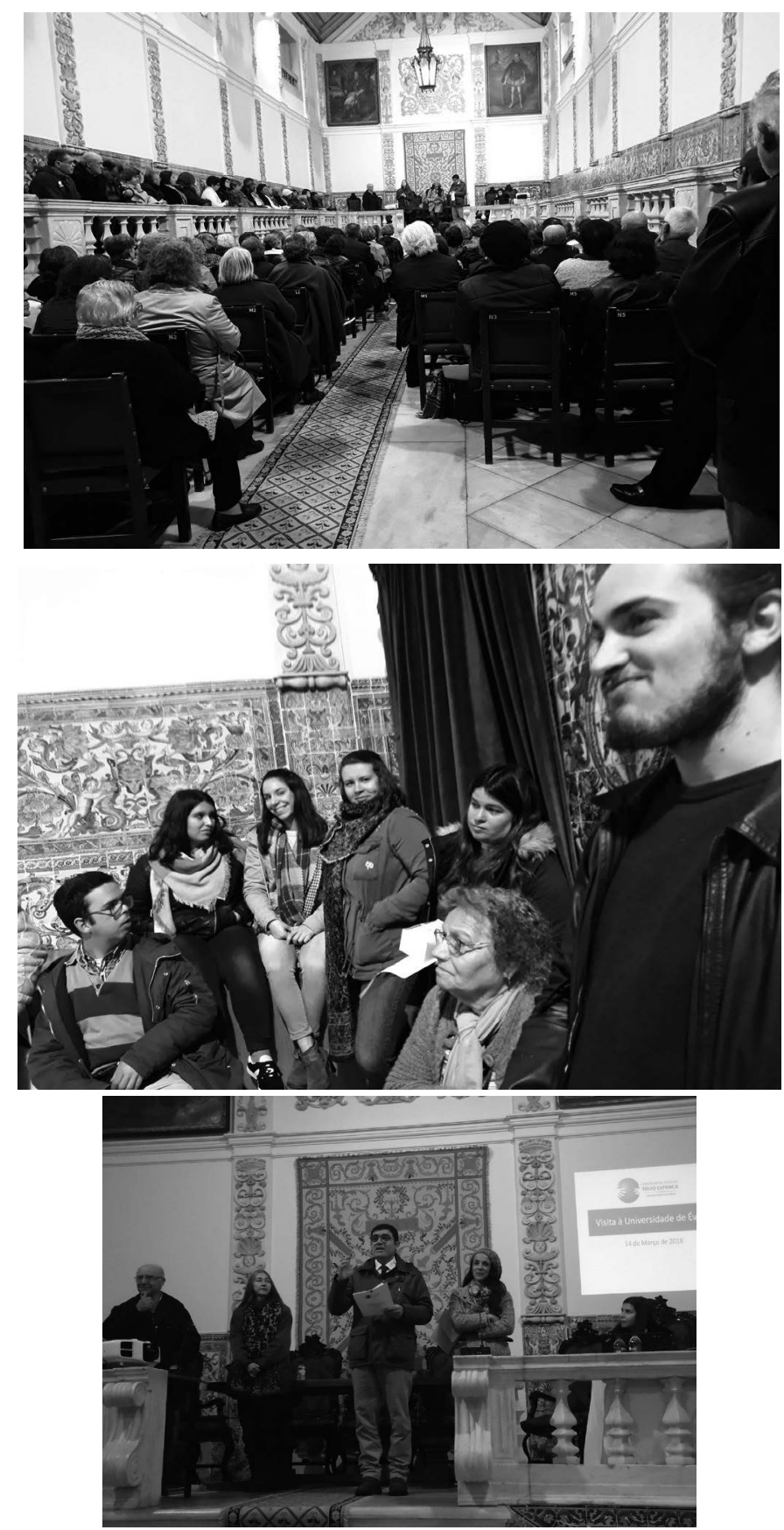

Figura 59. Visita de estudo pelos vários espaços da Universidade de Évora (Colégio do Espírito Santo) - parte da manhã 


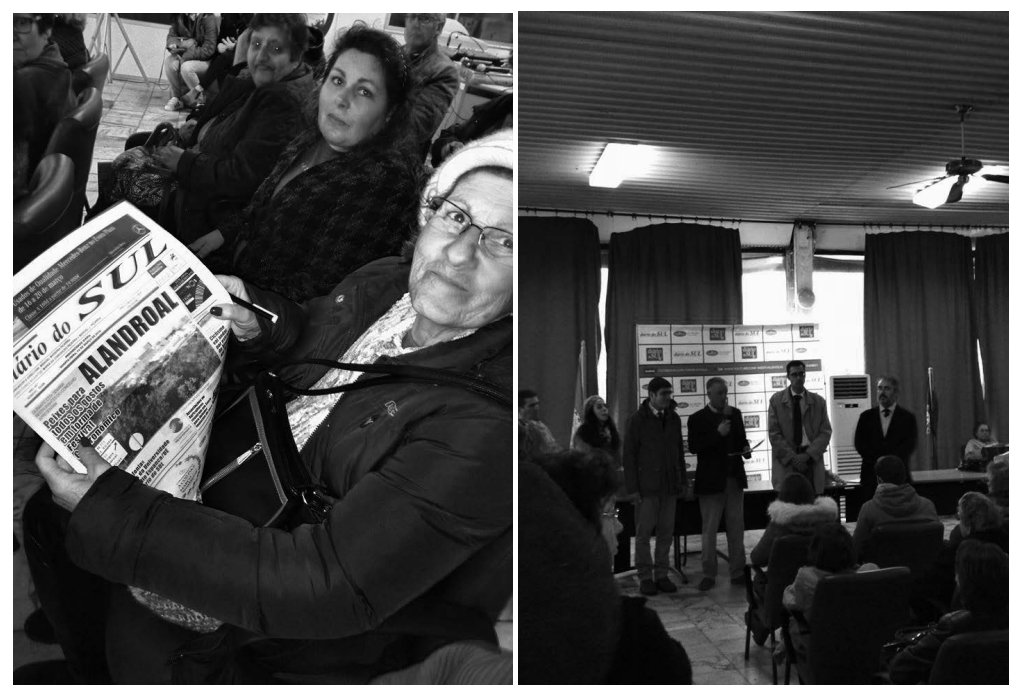

Figura 60. Visita de estudo pelo Grupo de Comunicação Social Diário do Sul - parte da tarde 


\section{CONCLUSÃO}

Ao longo das últimas páginas, mostraram-se algumas das mais significativas atividades de um dos projetos mais territorializados da Universidade de Évora: a Universidade Popular Túlio Espanca.

A Universidade Popular Túlio Espanca - criada e desenvolvida na Universidade de Évora e alicerçada na sua rede de polos localizados no Alentejo - é, na atualidade, uma realidade crescentemente apropriada pelo território e pelas comunidades que a ela têm vindo a aderir, num bom exemplo de entrosamento entre uma instituição de ensino superior e o seu contexto local e social.

Ao concretizar a missão da Universidade de Évora, nas suas três estruturais dimensões (investigação, formação e extensão), a Universidade Popular Túlio Espanca é, simultaneamente, um interessante exemplo de diálogo entre a academia e o território. Um diálogo com múltiplos protagonistas, no qual os conhecimentos académicos e experienciais se enriquecem mutuamente e onde o contacto humano entre pessoas de diferentes gerações e diversas origens sociais, económicas e sociais valoriza a formação de cada um/a.

Através da promoção e desenvolvimento da Universidade Popular Túlio Espanca, a Universidade de Évotra cumpre, também, o seu incontornável papel, no âmbito da Responsabilidade Social Institucional, dimensão fundamental de uma instituição pública de ensino superior.

Ao celebrar os dez anos de existência, a Universidade Popular Túlio Espanca apresenta-se como um projeto educativo com um passado e um futuro: o passado de uma história escrita a muitas mãos e com muitos contributos; um futuro, a ser escrito ainda por mais mãos e com mais protagonistas. Sempre com o firme propósito de construir oportunidades de acesso à Educação para o maior número possível de concidadãos.

«Eu gosto muito de ouvir/ cantar a quem aprendeu/

se houvera quem me ensinasse/quem aprendia era eu...» 


\section{REFERÊNCIAS BIBLIOGRÁFICAS}

D'OREY, J. (2009). Gestão Curricular Local: Fundamento para aquisição, desenvolvimento e valorização de competências em ciências naturais no ensino básico - A promoção da literacia científica no concelho de Alandroal (tese de doutoramento em Ciências da Educação não publicada). Évora: Universidade de Évora

NICO, B. \& COSTA, E. (2004). A experiência da formação conjunta: um exemplo de gestão curricular no âmbito da formação de professores na Universidade de Évora. Infância e Educação - Investigação e Práticas, (6), 145-149/ ISSN 0874-776 / (http://hdl.handle.net/10174/18865) / (http://dx.doi.org/10.5935/ref.20160026

NICO, B. (Coord.) (2011). Arqueologia das Aprendizagens em Alandroal. Mangualde: Edições Pedago / ISBN 978-989-844913-9/ (http://hdl.handle.net/10174/2894) (http://dx.doi. org/10.5935/978-989-8449-13-9.2016B001)

NICO, B. (Coord.). NICO, L., TOBIAS, A., VALADAS, F. \& FERREIRA, F. (Orgs.) (2013). Atlas da Educação em Alandroal. Mangualde: Edições Pedago \& Universidade de Évora/ ISBN 978-989-865513-4/ (http://hdl.handle.net/10174/18808) / (http://dx.doi. org/10.5935/978-989-8655-13-4.2016B001)

NICO, B. (Coord.), NICO, L., TOBIAS, A., VALADAS, F. \& FERREIRA, F. (2013). Carta Educativa do Concelho de Alandroal/Revisão de Julho de 2013. Alandroal: Câmara Municipal de Alandroal e Centro de Investigação em Educação e Psicologia da Universidade de Évora/ ISBN 978-989-8339-15-7/ (http://hdl.handle.net/10174/18810) / (http:// dx.doi.org/10.5935/978-989-8339-15-7.2016B001)

NICO, B. (2016). Anexo Técnico da candidatura do Projeto «Currículo, Educação Popular e Responsabilidade Social na Universidade». Évora: Universidade Popular Túlio Espanca/Universidade de Évora

NICO, B. \& NICO, L. (2016a). Janelas Curriculares de Educação Popular na Universidade de Évora: para um conhecimento académico mais humanista e solidário. Ramada: Edições Pedago e Universidade Popular Túlio Espanca da Universidade de Évora / ISBN 978-989-8655-73-8 / 
(http://dspace.uevora.pt/rdpc/handle/10174/18917) / (http://dx.doi. org/10.5935/978-989-8655-73-8.2016B001)

NICO, B. \& NICO, L. (Orgs.) (2016b). Didáticas do Alentejo. Ramada: Edições Pedago e Universidade de Évora / ISBN 978-989-8655-73-8 / (http://dspace.uevora.pt/rdpc/handle/10174/18918) / (http://dx.doi. org/10.5935/978-989-8655-74-5.2016B001)

NICO, B. \& NICO, L. (2017). Currículo, Educação Popular e Responsabilidade Social na Universidade de Évora. Revista de Estudios e Investigación em Psicología Y Educación, vol. Extra, (10), 58-60/ ISSN 2386-7418 (https:// doi.org/10.17979/reipe.2017.0.10.2650)

NICO, B. (2012). Relatório Final do Projeto "Arqueologia das Aprendizagens no concelho de Alandroal”. Évora: Centro de Investigação em Educação e Psicologia da Universidade de Évora/ (http://hdl.handle.net/10174/19351 ) / (http://dx.doi.org/10.5935/ref.20160087)

NICO, B. (2016). Relatório Final do Projeto "Janelas Curriculares de Educação Popular no Ensino Universitário”. Évora. Universidade Popular Túlio Espanca/Universidade de Évora/ (http://hdl.handle.net/10174/19362) / (http://dx.doi.org/10.5935/ref.20160089)

/http://dx.doi.org/10.5935/ref.20160092)

NICO, B. \& NICO, L. (Orgs.) (2018).Aprenderes no Alentejo. Ramada: Edições de Facto.

\section{Legislação referenciada}

Despacho Normativo n. ${ }^{\circ}$ 10/2014, publicado no Diário da República n. ${ }^{\circ}$ 149, Série II de 5 de Agosto de 2014. 
